\title{
WestVirginiaUniversity
}

THE RESEARCH REPOSITORY @ WVU

Graduate Theses, Dissertations, and Problem Reports

2011

\section{Time-Dependent Performance of Buried Pipes in a Consolidating Soil Medium}

Laura A. Sesack

West Virginia University

Follow this and additional works at: https://researchrepository.wvu.edu/etd

\section{Recommended Citation}

Sesack, Laura A., "Time-Dependent Performance of Buried Pipes in a Consolidating Soil Medium" (2011). Graduate Theses, Dissertations, and Problem Reports. 4786.

https://researchrepository.wvu.edu/etd/4786

This Thesis is protected by copyright and/or related rights. It has been brought to you by the The Research Repository @ WVU with permission from the rights-holder(s). You are free to use this Thesis in any way that is permitted by the copyright and related rights legislation that applies to your use. For other uses you must obtain permission from the rights-holder(s) directly, unless additional rights are indicated by a Creative Commons license in the record and/ or on the work itself. This Thesis has been accepted for inclusion in WVU Graduate Theses, Dissertations, and Problem Reports collection by an authorized administrator of The Research Repository @ WVU. For more information, please contact researchrepository@mail.wvu.edu. 


\title{
Time-Dependent Performance of Buried Pipes in a Consolidating Soil Medium
}

\author{
Laura A. Sesack \\ Thesis submitted to the \\ College of Engineering and Mineral Resources \\ at West Virginia University \\ in partial fulfillment of the requirements \\ for the degree of
}

Master of Science

in

Civil \& Environmental Engineering

\author{
Hema J. Siriwardane, Ph.D., Chair \\ Udaya B. Halabe, Ph.D. \\ John D. Quaranta, Ph.D.
}

Morgantown, West Virginia

2011

Keywords: HDPE pipe; PVC pipe; Consolidation; Creep; FEM 


\begin{abstract}
Time-Dependent Performance of Buried Pipes in a Consolidating Soil Medium
\end{abstract}

\author{
Laura A. Sesack
}

Buried pipes are used for several applications, including water conveyance, highway drainage, and the transport of sewage. Throughout the years, it has become increasingly popular to use pipes made of thermoplastic materials due to ease of fabrication, resistance to chemical corrosion, light weight, and low cost. The objective of this research was to investigate the deformations of buried double-corrugated high-density polyethylene (HDPE) and solid-wall polyvinylchloride (PVC) pipes surrounded by a consolidating soil medium. The finite element method was used to calculate the pipe deflections throughout a time period of fifty years. Combined influence of creep and soil consolidation was considered in the analyses, and the results from these analyses were then compared to the deformations of pipes only influenced by the creep of the pipe material. Variables of this study included pipe diameter, height of backfill, pipe backfill material, construction methods, trench-widths, and boundary conditions.

Results show that approximately $90 \%$ of pipe deformations occurred during the first year of installation for both the creep analyses and the combined creep and consolidation analyses. However, throughout the first year, the pipe influenced by both the creep and consolidation condition deformed at a much slower rate. Pipes influenced only by the creep condition showed a slightly higher deformation than pipes influenced by both creep and consolidation. This may be due to the instantaneous loading of the pipe, when there is no consolidation. When a pipe is surrounded by a consolidating soil medium, the load on the pipe changes as the pore pressure dissipates as a function of time. Results from the analyses of the combined influence of creep and consolidation are not significantly different from those results obtained from the analyses of creep only behavior of buried HDPE and PVC pipes under the self-weight of soil. 


\section{ACKNOWLEDGEMENTS}

I would like to take this opportunity to thank the people who have played a vital role in the completion of this thesis. Firstly, I would like to thank my advisor and committee chairperson, Dr. Hema Siriwardane. He has offered his guidance and support throughout the duration of this project. I would also like to thank Dr. Udaya Halabe and Dr. John Quaranta for participating in my exam committee and reviewing my thesis.

I gratefully acknowledge the West Virginia Department of Transportation, Division of Highways for the Research assistantship provided through a project to West Virginia University.

I would like to express my deep appreciate to my family and friends for their support and love. 


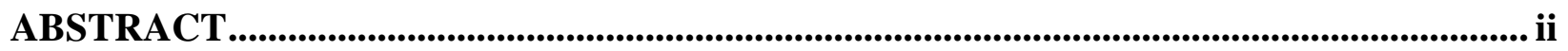

ACKNOWLEDGEMENTS ……............................................................................................ iii

LIST OF FIGURES .......................................................................................................................... vii

LIST OF TABLES ...................................................................................................................... $\mathrm{x}$

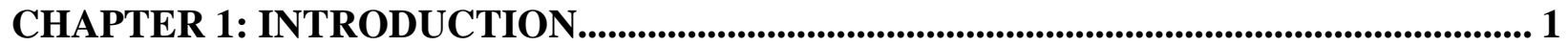

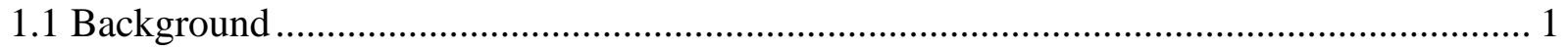

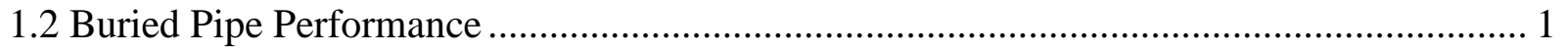

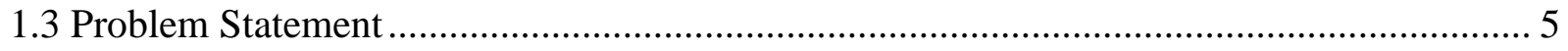

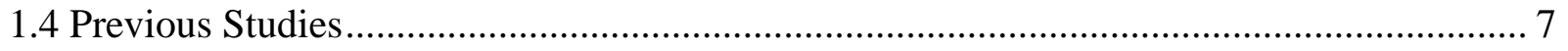

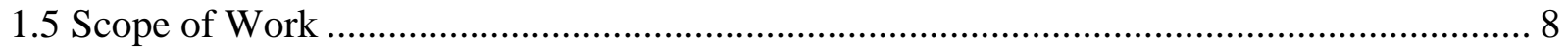

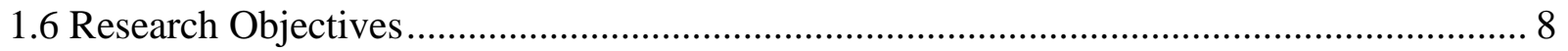

CHAPTER 2: PERFORMANCE OF BURIED FLEXIBLE PIPES ...................................... 10

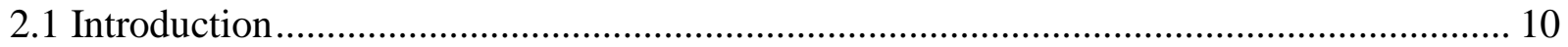

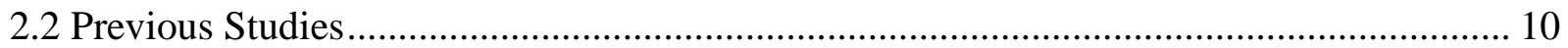

2.3 Factors Influencing Pipe Performance........................................................................... 12

2.4 Pipe Deflections ..................................................................................................... 12

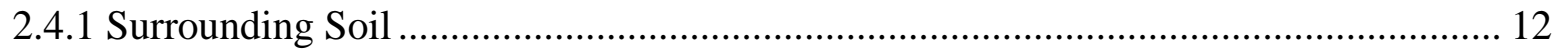

2.4.2 Parallel Plate Loading Test ...................................................................................... 13

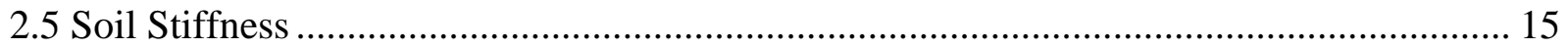

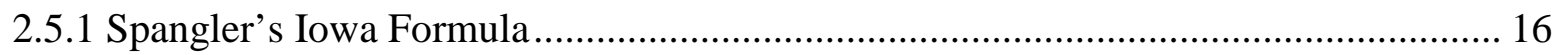

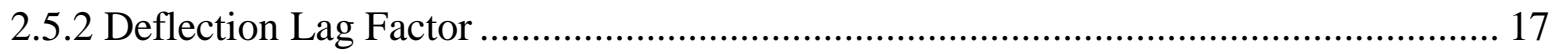

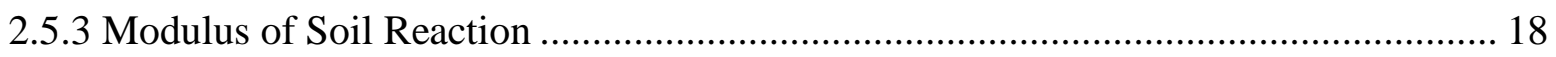

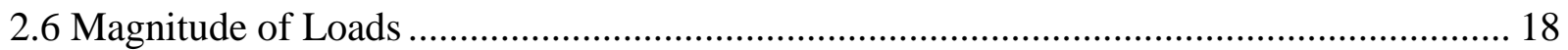

2.6.1 Gravity Loading (Geostatic Loading) ................................................................... 18

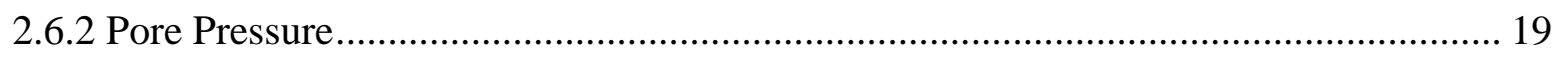

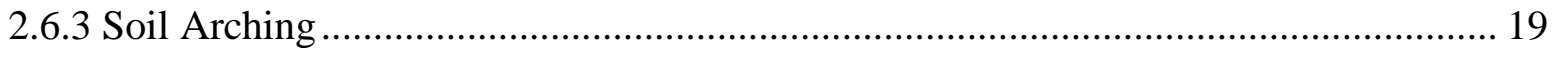

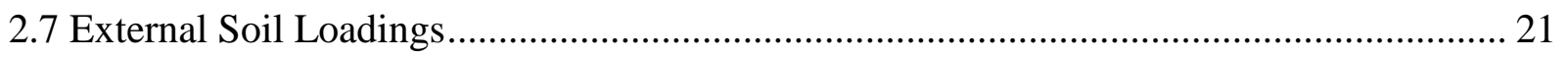

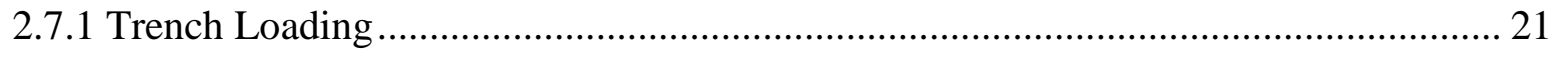

2.7.2 Embankment Loading ............................................................................................... 21

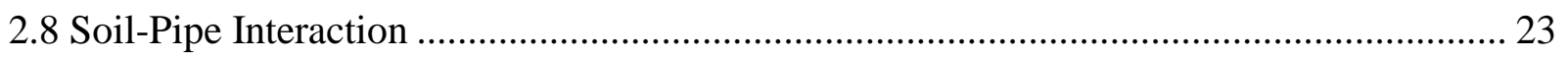




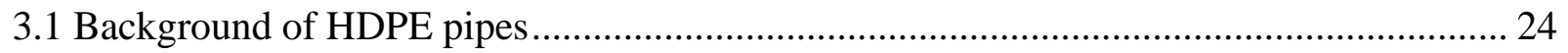

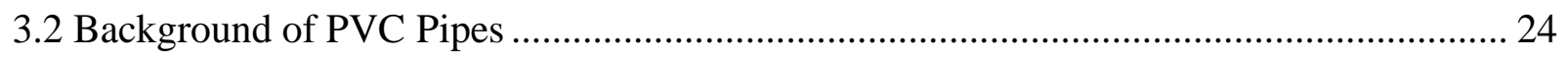

3.3 Introduction to Time-Dependent Behavior of Pipes ............................................................. 25

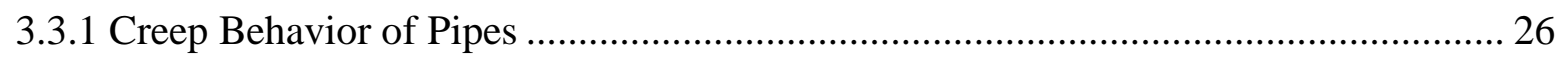

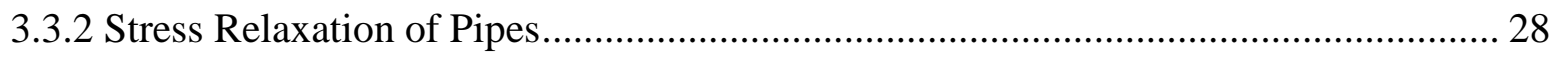

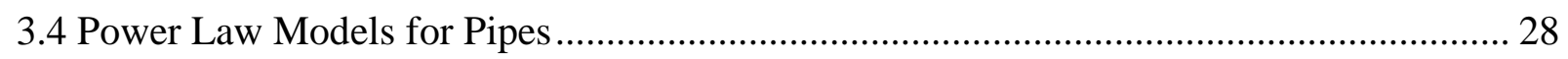

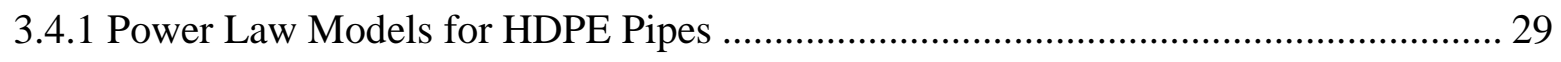

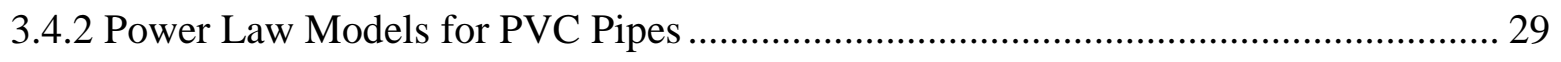

3.5 Properties of Double-wall Corrugated HDPE Pipes ......................................................... 30

3.5.1 Geometric and Material Details of Double-wall Corrugated HDPE Pipes................... 30

3.6 Properties of Solid-wall PVC Pipes ............................................................................. 36

3.7 Introduction to Time-Dependent Behavior of Soil ............................................................ 37

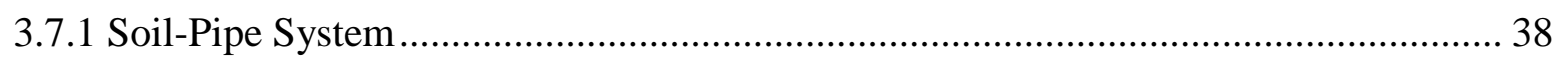

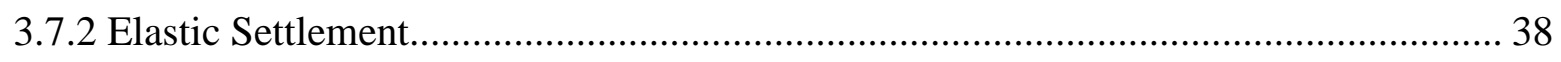

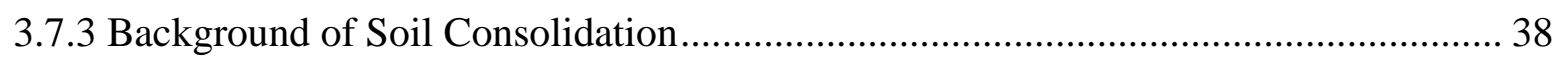

3.7.4 Influence of Pore Pressure on Buried Pipes............................................................... 39

\section{CHAPTER 4: INFLUENCE OF SOIL CONSOLDATION ON THE PERFORMANCE OF

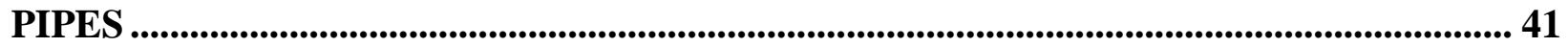

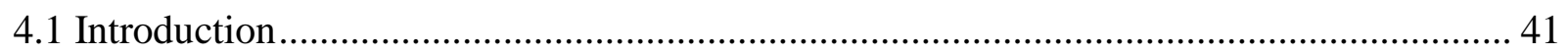

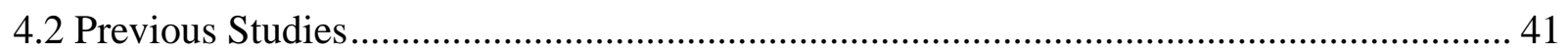

4.3 Finite Element Analysis ............................................................................................. 42

4.4 Creep Formulation in the Finite Element Analysis............................................................. 48

4.5 Finite Element formulation of Soil Consolidation.............................................................. 50

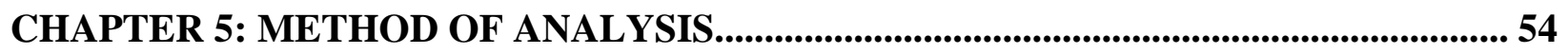

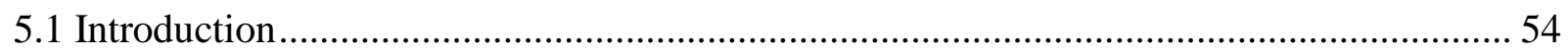

5.2 Creep and Consolidation Analysis.............................................................................. 54

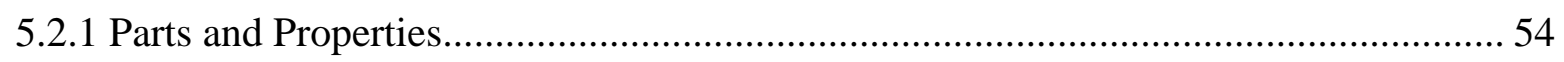

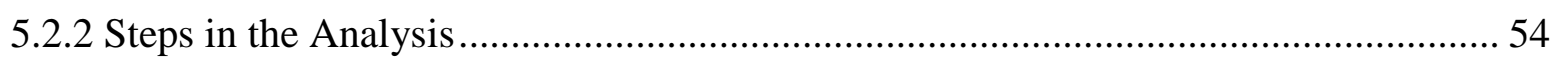

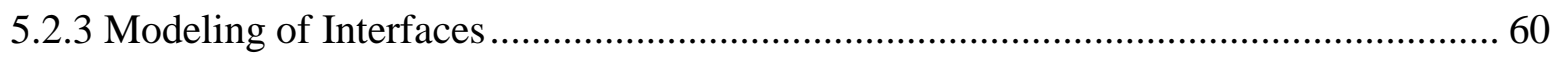

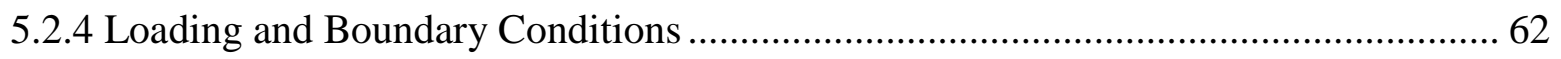

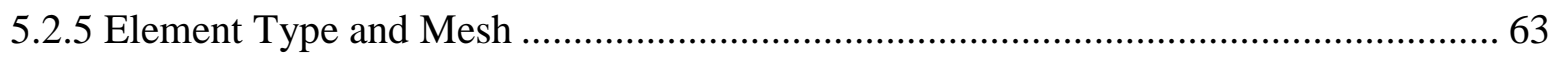

5.2.6 Drainage Conditions ............................................................................................. 63 
CHAPTER 6: RESULTS AND DISCUSSIONS ................................................................. 70

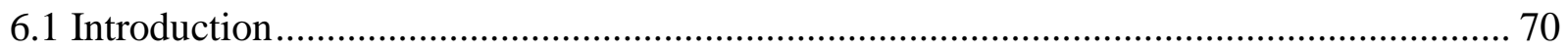

6.2 Results of HDPE Pipes Influenced by Creep and Soil Consolidation ............................. 70

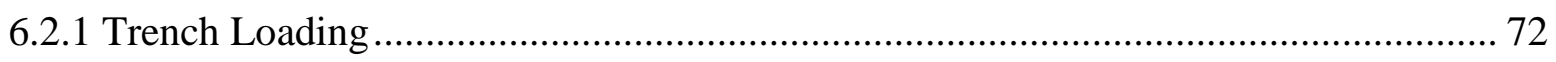

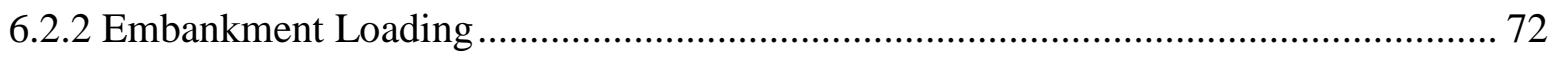

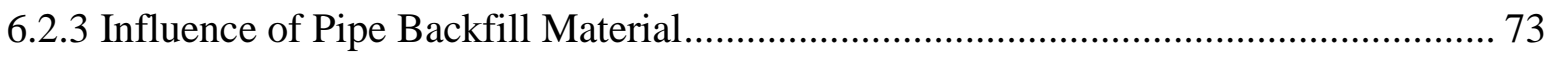

6.2.4 Influence of Trench-Width Ratio........................................................................ 75

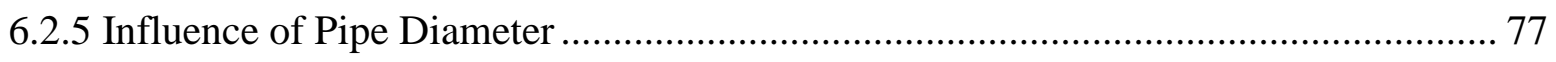

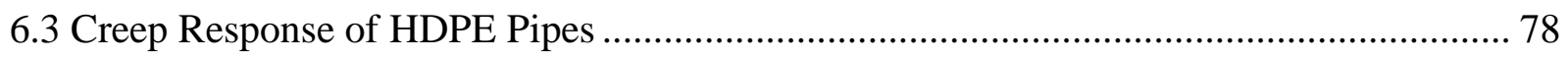

6.4 Combined Influence of Creep and Consolidation..................................................... 80

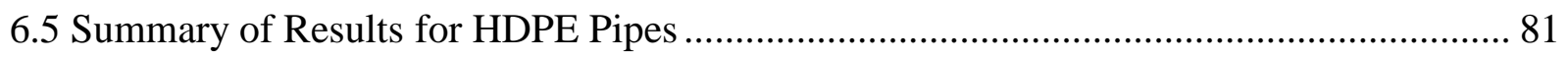

6.6 Results of Solid-Wall PVC Pipes Influenced by Creep and Soil Consolidation ................ 86

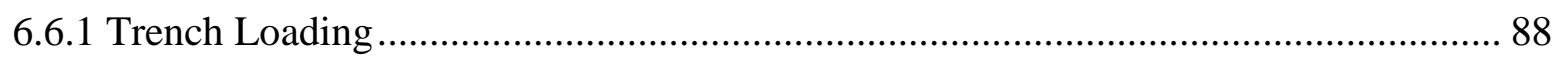

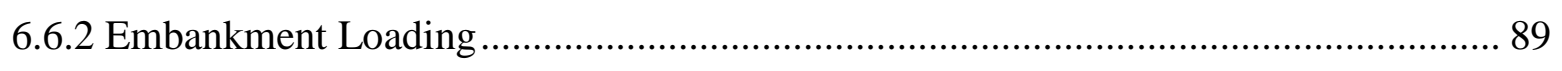

6.6.3 Influence of Pipe Backfill Material...................................................................... 90

6.6.4 Influence of Trench-width Ratio....................................................................... 92

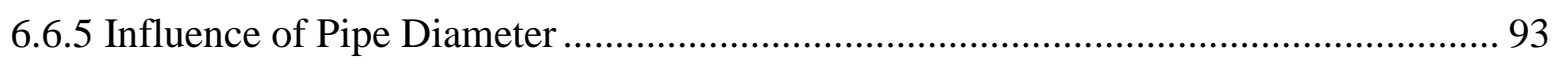

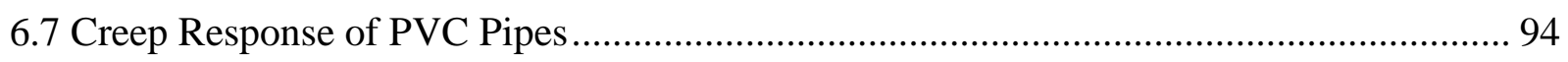

6.8 Combined Influence of Creep and Consolidation...................................................... 97

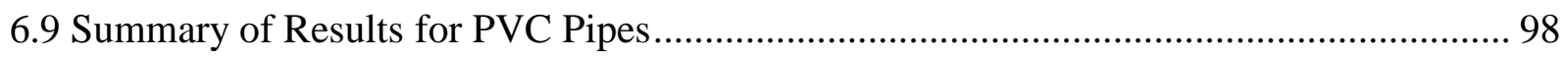

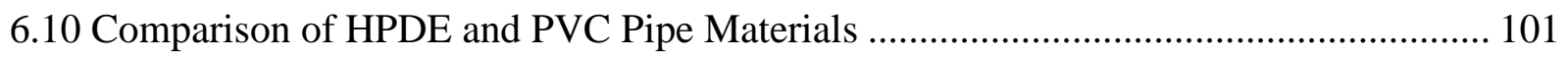

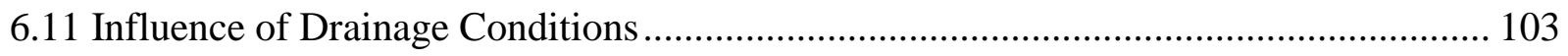

CHAPTER 7: SUMMARY AND CONCLUSIONS .............................................................. 104

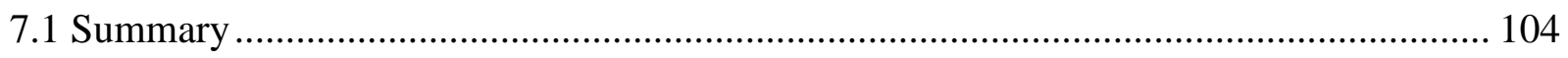

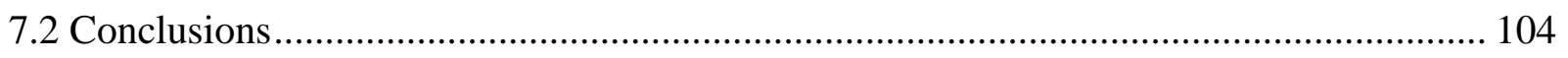

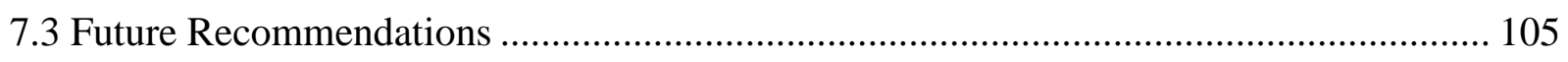

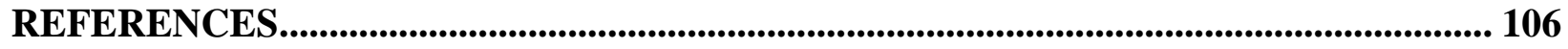

APPENDIX A: CREEP RESULTS...................................................................... 111

APPENDIX B: COMPARISON OF TIME-DEPENDENT PIPE DEFLECTIONS.......... 117 


\section{LIST OF FIGURES}

Figure 1.1: Typical cross-section of a pipe (Watkins, 2000) ..................................................2

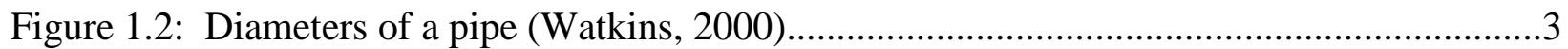

Figure 1.3: Typical cross-section of a buried pipe with trench backfill ......................................3

Figure 1.4: Typical cross-section of a buried pipe with embankment ........................................4

Figure 1.5: 3-Dimensional view of a buried pipe under trench loading ......................................4

Figure 1.6: 3-Dimensional view of a buried pipe under embankment loading .............................5

Figure 1.7: Soil and pipe cross-sections under different construction methods .........................6

Figure 1.8: Surface drainage and soil/pipe interface drainage conditions ..................................7

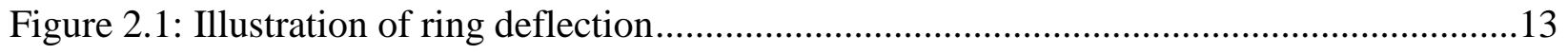

Figure 2.2: Parallel plate testing (ASTM 2412 Test) for flexible pipes ....................................15

Figure 2.3: Basis of Spangler's derivation of the Iowa formula for deflection of buried pipes ....17

Figure 2.4: Schematic of soil prism over conduit ...............................................................20

Figure 2.5: Mechanism of soil arching within soil-pipe system (Kang, 2009)..........................20

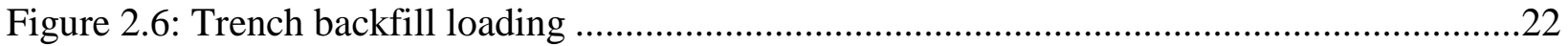

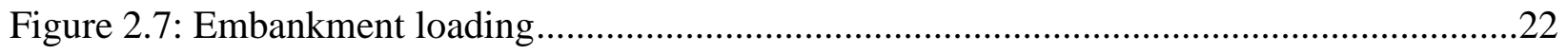

Figure 3.1: Typical Double-wall corrugated HDPE pipe …...................................................25

Figure 3.2: Graphs from strain and strain rate due to constant stress creep test.........................27

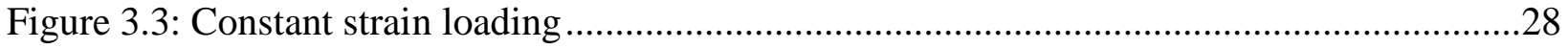

Figure 3.4: Cross-section of a double-wall corrugated HDPE pipe...........................................34

Figure 3.5: Time vs. deformation plot during consolidation .................................................40

Figure 4.1: Two-noded beam element .................................................................................42

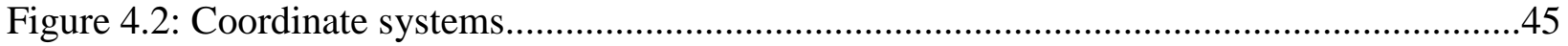

Figure 5.1: Cross-section of a pipe-soil model ...................................................................55

Figure 5.2: Soil and HDPE pipe properties used in the present study .......................................57

Figure 5.3: Soil and PVC pipe properties used in present study ..............................................58

Figure 5.4: Finite element mesh show interfaces..................................................................61

Figure 5.5: Loading and boundary conditions .................................................................62 
Figure 5.6: Drainage conditions.

Figure 6.1: Displacements of a 60-inch HDPE pipe buried in granular material under 20 feet of trench backfill and a trench width ratio of 2.0 .

Figure 6.2: Displacements of a 60-inch HDPE pipe buried in granular material under 50 feet of

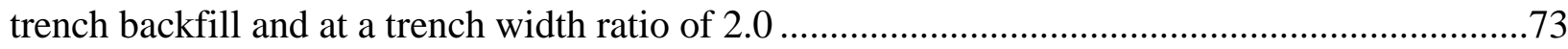

Figure 6.3: Vertical pipe deflection for a 60-inch HDPE pipe installed at a depth of 50 feet.......74

Figure 6.4: Deflections of a 60-inch HDPE pipe with clay backfill material .............................74

Figure 6.5: Deflections of a 60-inch HDPE pipe with granular stone backfill material...............75

Figure 6.6: Effect of trench-width for a 60-inch HDPE pipe with clay backfill material ............76

Figure 6.7: Effect of trench-width for a 60-inch HDPE pipe with granular backfill material.......76

Figure 6.8: Deflection of various HDPE pipe diameters with clay backfill material ...................77

Figure 6.9: Deflection of various HDPE pipe diameters with granular stone ............................78

Figure 6.10: Vertical pipe deflection for a 60-inch HDPE pipe installed at a depth of 50 feet.....79

Figure 6.11: Deflections of a 60-inch HDPE pipe with clay backfill material...........................79

Figure 6.12: Deflections of a 60-inch HDPE pipe with granular stone backfill.........................80

Figure 6.13: Comparison of pipe deflection under trench backfill height of 50 feet with clay backfill

Figure 6.14: Displacements of a 24-inch PVC pipe buried in granular material under 20 feet of trench backfill and at a trench width ratio of 2.0 .....

Figure 6.15: Displacements of a 24-inch PVC pipe buried in granular material under 50 feet of trench backfill and a TW ratio of 2.0 .

Figure 6.16: Vertical pipe deflection for a 24-inch PVC pipe installed at a depth of 50 feet .......90

Figure 6.17: Pipe deflections for a 24-inch PVC pipe with clay backfill material .......................91

Figure 6.18: Pipe deflections for a 24-inch PVC pipe with granular stone backfill....................91

Figure 6.19: Effect of trench-width ratio for a 24-inch PVC pipe with clay backfill...................92

Figure 6.20: Effect of trench-width ratio for a 24-inch PVC pipe with granular backfill .............93

Figure 6.21: Deflection of various PVC pipe diameters with clay backfill material...................94

Figure 6.22: Deflection of various PVC pipe diameters with granular stone backfill.................94

Figure 6.23: Vertical pipe deflection for a 24-inch PVC pipe installed at a depth of 50 feet .......95

Figure 6.24: Pipe deflections for a 24-inch PVC pipe with clay backfill material ......................96

Figure 6.25: Pipe deflections for a 24-inch PVC pipe with granular stone backfill.....................96 
Figure 6.26: Comparison of pipe deflection for 24-inch PVC pipe under 50 feet of backfill in a trench-width of 2.0 with clay backfill .....................................................................................97

Figure 6.27: Comparison of both pipe materials: 24-inch diameter with granular backfill under a trench backfill height of 50 feet and with a trench-width ratio of 2.0 .......................................102

Figure 6.28: Comparison of both pipe materials: 24-inch diameter with clay backfill under a

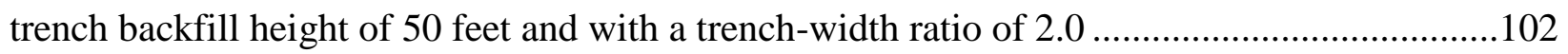

Figure 6.29: Comparison of drainage boundary conditions.........................................................103 


\section{LIST OF TABLES}

Table 3.1: Section properties of dual-wall corrugated HDPE pipes (ADS Inc., 2006) .................31

Table 3.2: Sectional properties for HDPE used in research study (ADS Inc., 2006) ...................35

Table 3.3: Modified geometric and material properties for pipes used in this study....................36

Table 3.4: Specification Data for PVC Pipes (Diamond Plastics, 2005) ...................................37

Table 3.5: Sectional properties of PVC pipe used in research study (Diamond Plastics, 2005) ...37

Table 4.1: Creep constants used for PVC and HDPE pipe materials .......................................50

Table 5.1: Soil properties used in the present study ............................................................56

Table 5.2: Pipe properties used in the present study .............................................................56

Table 5.3: Steps used for trench backfill loading analyses ...................................................59

Table 5.4: Steps used for embankment loading analyses .....................................................60

Table 5.5: Boundary conditions used in present study ......................................................65

Table 5.6: Soil properties used in current study …...........................................................67

Table 5.7: Pipe properties used in current study ...............................................................67

Table 5.8: Trench loading time steps used for creep analysis ................................................68

Table 5.9: Embankment loading time steps used for creep analysis .......................................69

Table 6.1: Case studies for HDPE pipe placed in clay backfill material ....................................71

Table 6.2: Case studies for HDPE pipe placed in granular stone backfill material.....................71

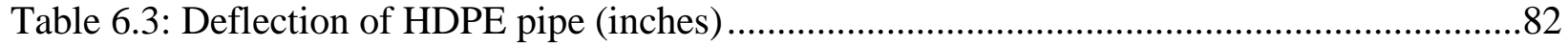

Table 6.4: Deflection of HDPE pipe (percentage) .................................................................83

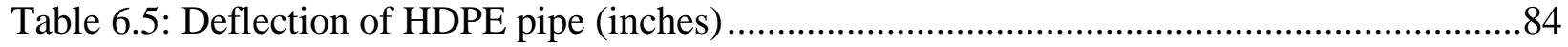

Table 6.6: Deflection of HDPE pipe (percentage) ...............................................................85

Table 6.7: Cases for PVC pipe buried in clay and influenced by creep and soil consolidation ....86

Table 6.8: Cases for PVC pipe buried in granular material and influenced by creep and soil

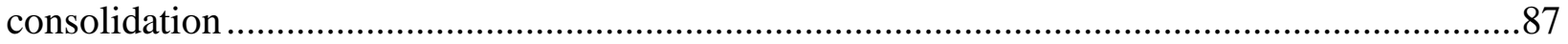

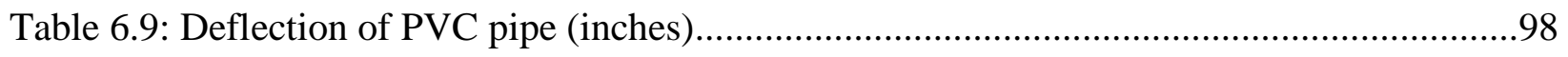

Table 6.10: Deflection of PVC pipe (percentage) ..................................................................99

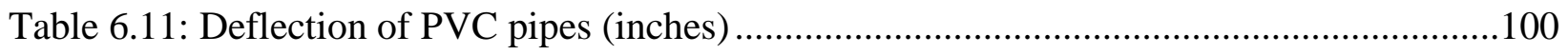


Table 6.12: Deflection of PVC pipe (percentage) 


\section{CHAPTER 1: INTRODUCTION}

\subsection{Background}

Buried pipes have been used for water, sewer, and storm water conveyance. It is becoming more popular for these buried pipes to be made of thermoplastic materials, such as high-density polyethylene (HDPE) and polyvinylchloride (PVC) (Zhang, 1998). Factors encouraging the use of thermoplastic materials for buried pipes include ease of fabrication, resistance to chemical corrosion, light weight of the materials, and low cost (Zhang, 1998; Masada \& Sargand, 2007). Buried pipe design and construction methods have been improved to enhance pipe performance. The service life of HDPE and PVC pipes are a major concern in the design of plastic piping systems (Zhao et al., 2001). Failures of buried pipes include compression of the pipe, elastic instability, or buckling (Zhao et al., 2001).

The soil-pipe interaction and pipe backfill material selection are key aspects in flexible buried pipe design. Compared to rigid pipes, flexible pipes have lower strength. The ability of flexible pipes to support vertical loadings is a result of the passive pressures induced on the pipe as the sides of the pipe move outward against the soil (Spangler, 1941). As defined by the American Association of State Highway and Transportation Officials (AASHTO), a buried pipe is a composite structure made of a plastic ring surrounded by a soil envelope. Soil-pipe interaction is influenced by factors such as soil type, soil density, moisture content, pipe stiffness and depth of installation (Moser, 1990). Factors influencing the selection of materials for pipe backfill include depth of cover, depth of water table, pipe materials, and compaction methods (Moser, 1990).

\subsection{Buried Pipe Performance}

Buried pipe performance is a function of external loading, geometry, and material properties of both pipe and soil (Watkins, 2000). Performance limits are directly related to stress, strain, deflection, or buckling (Moser, 1990). The forces acting on a buried pipe are statically indeterminate and are unable to be determined if the soil is not uniform (Watkins, 
2000). The soil load acting on a flexible pipe may be reduced because the soil arches over the pipe, relieving the pipe of some stress. External loading and the soil arching phenomenon are the causes of flexible pipe deformation (Watkins, 2000). From the results of a parallel plate test gathered by the American Society for Testing and Materials (ASTM), allowable stiffness of a plastic pipe is calculated at a $5 \%$ vertical deflection (Suleiman et al, 2003). Pipe deflection occurs instantaneously and continues to develop over the years due to creep of the pipe and soil consolidation acting around the pipe.

A typical pipe profile and geometric details are given in Figures 1.1 and 1.2, respectively. A typical cross-section of a buried pipe with trench backfill is shown in Figure 1.3, and a crosssection of a buried pipe under an embankment loading is shown in Figure 1.4. Figures 1.5 and 1.6 show three-dimensional views of a pipe buried under a trench backfill loading and embankment loading, respectively.

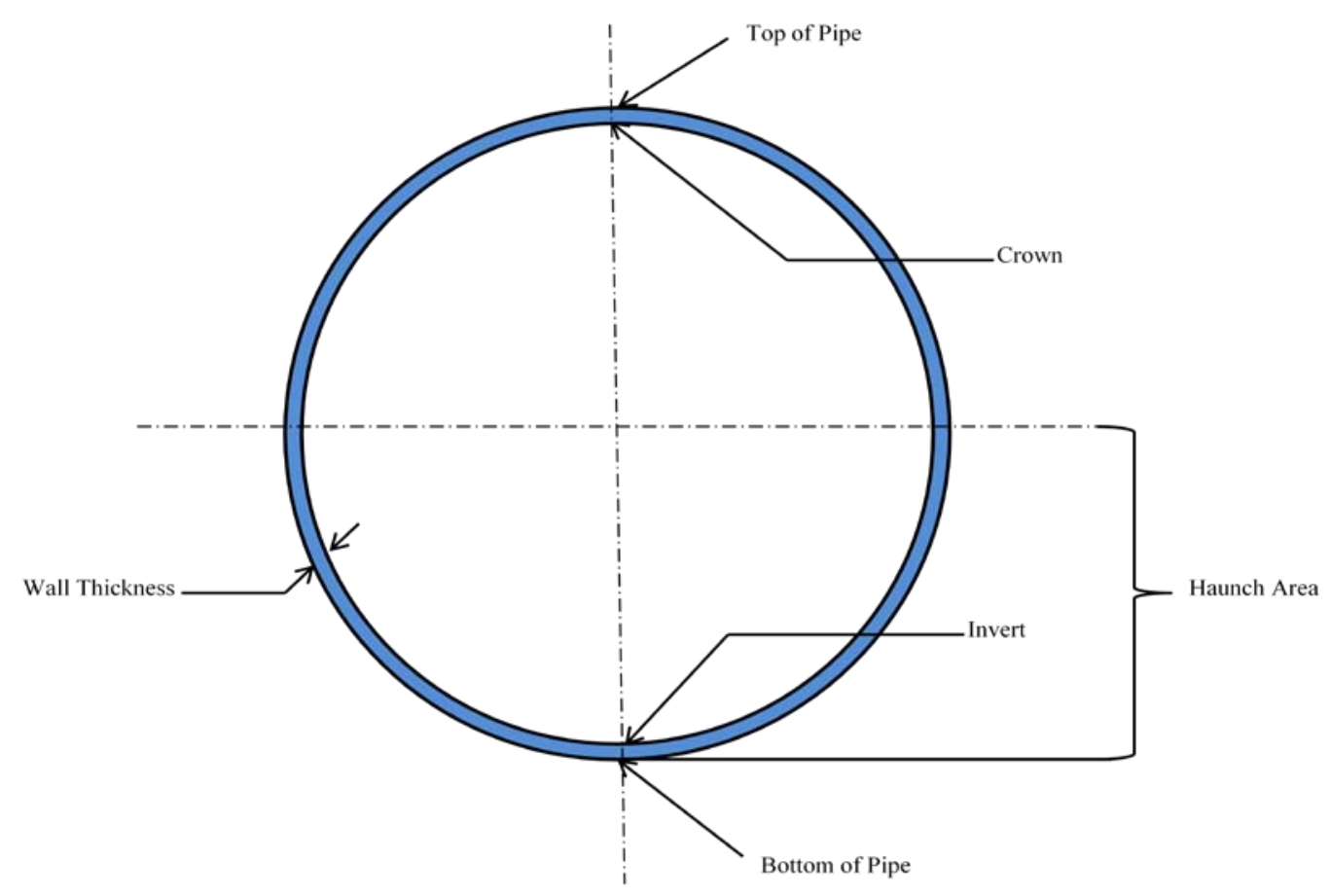

Figure 1.1: Typical cross-section of a pipe (Watkins, 2000) 


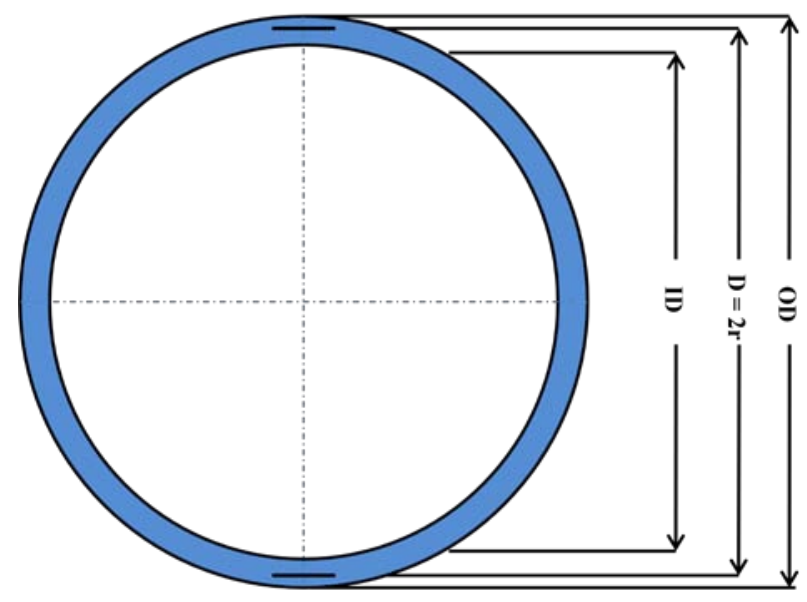

where

$$
\begin{aligned}
& \text { ID }=\text { Inner Diameter } \\
& \text { OD }=\text { Outer Diameter } \\
& r \quad=\text { Radius }
\end{aligned}
$$

Figure 1.2: Diameters of a pipe (Watkins, 2000)

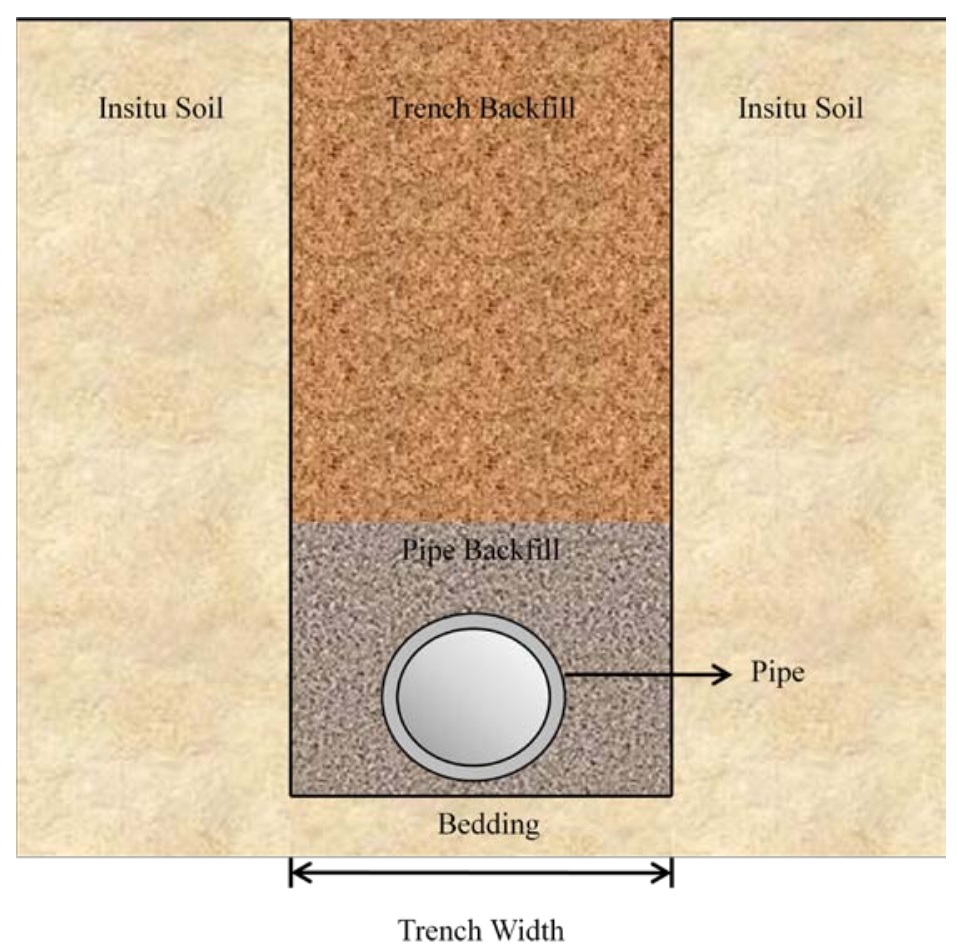

Figure 1.3: Typical cross-section of a buried pipe with trench backfill 


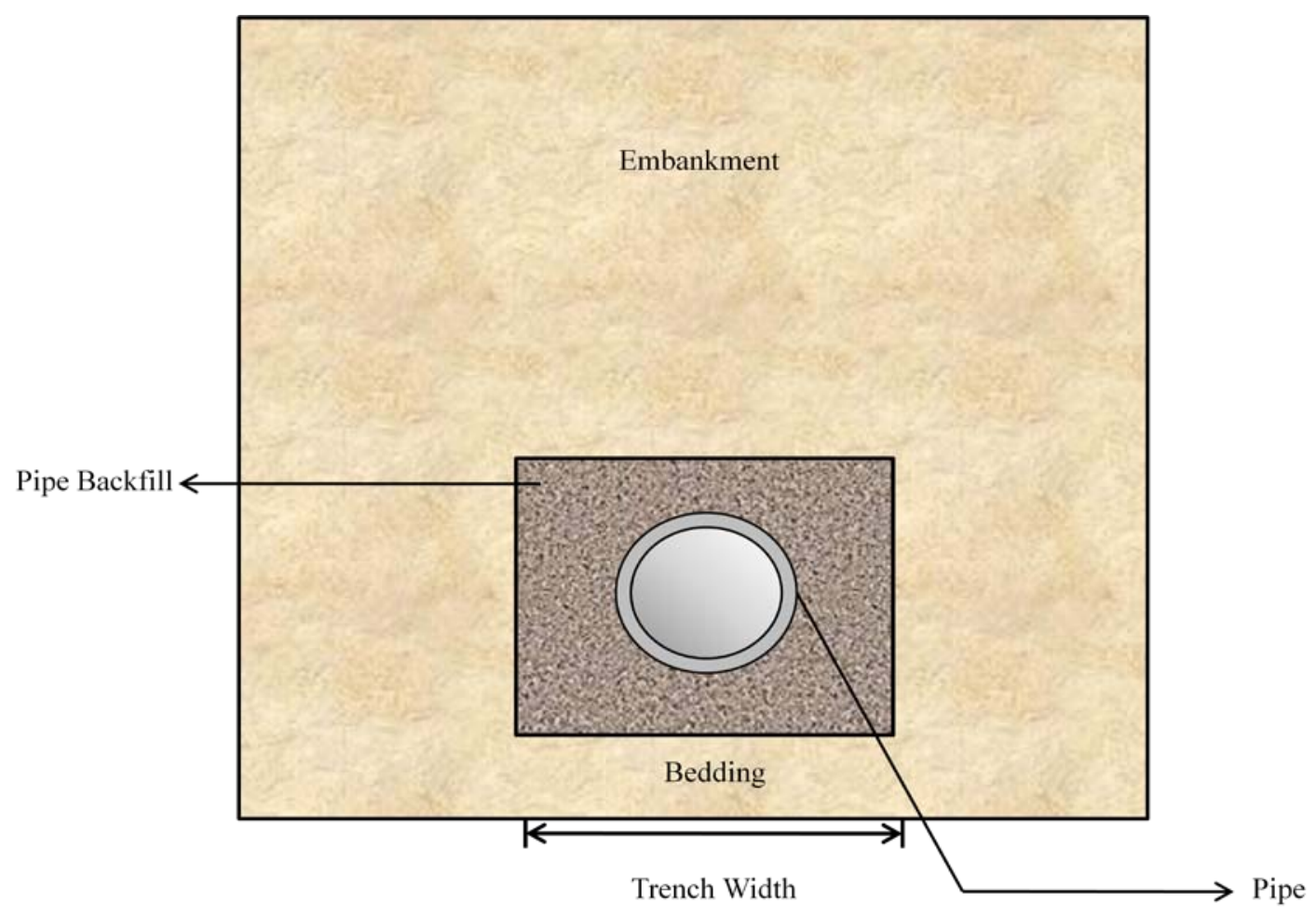

Figure 1.4: Typical cross-section of a buried pipe with embankment

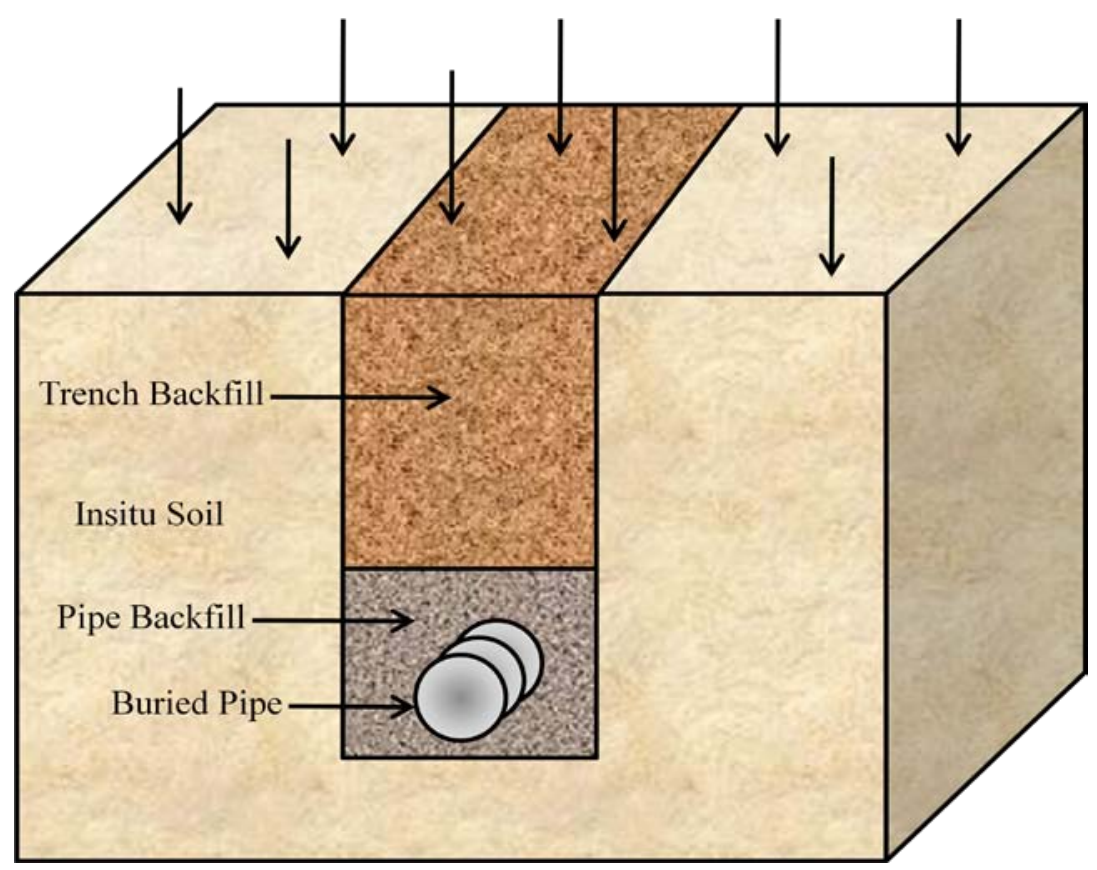

Figure 1.5: 3-Dimensional view of a buried pipe under trench loading 


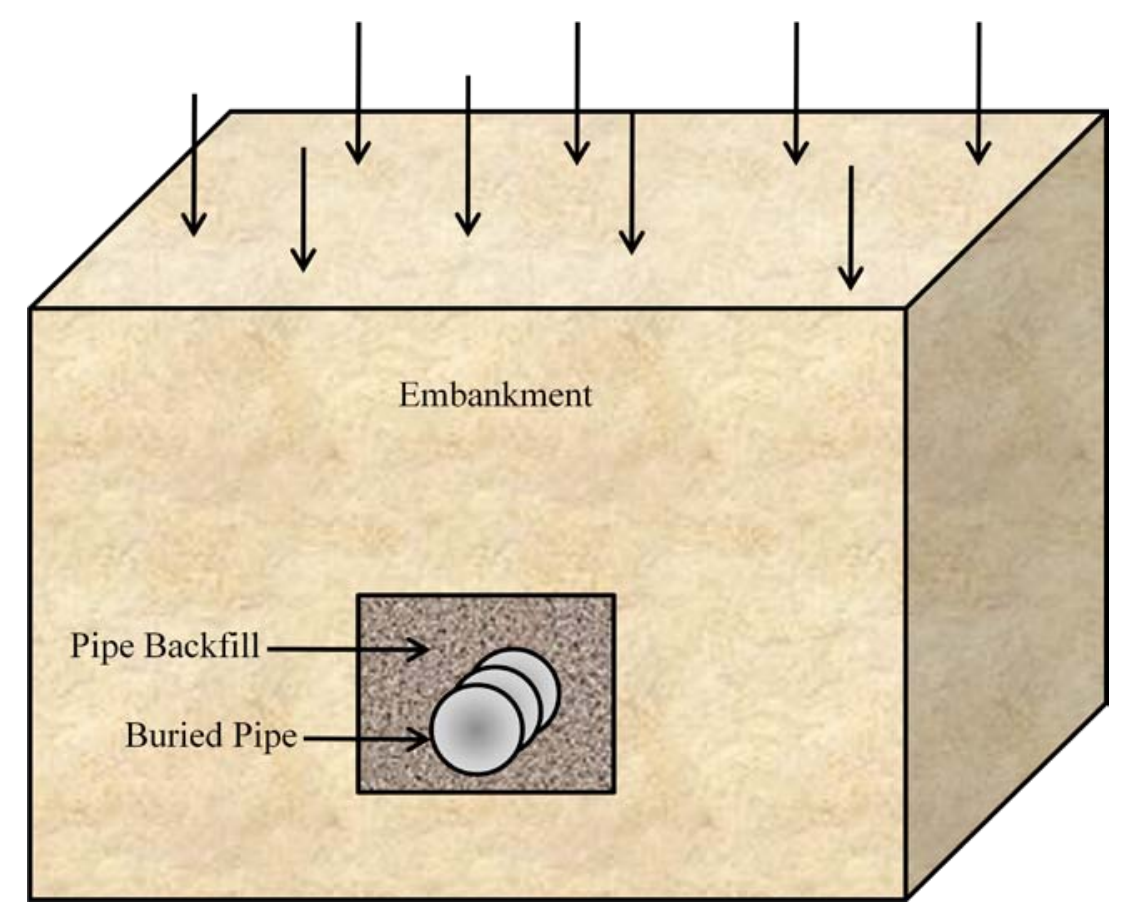

Figure 1.6: 3-Dimensional view of a buried pipe under embankment loading

\subsection{Problem Statement}

In the present study, the combined influence of creep behavior of buried HDPE and PVC pipes and the effects of surrounding soil consolidation on the pipe response is investigated. Creep is defined as the continuous deformation of a material subjected to a constant load. The rate of creep is a function of temperature, stress, and time (Moser, 2008). Soil consolidation occurs when a load acts on a saturated soil. Total stress remains constant as effective stress increases and pore pressure decreases (Helwany, 2007). The rate of consolidation is a function of the permeability of soil, compressibility of the soil, and length of the drainage path (Helwany, 2007; Das, 2006).

Two different pipe installations are considered in this study: (a) pipe installed in a trench, and (b) pipe installed under an embankment. Pipes installed in a trench at depths of 10 feet to 20 
feet (Figure 1.7(a)) are considered in the analysis. Trenches are generally used for shallow depths up to 20 feet (Spangler \& Handy, 1982). For fill heights greater than 30 feet, embankment loading (Figure 1.7(b)) is considered in the analysis. The worst case scenario for a buried pipe is when it is under an embankment loading (Watkins, 2000). Embankment loads acting on a buried pipe could potentially be greater than the weight of the overlying soil (Spangler \& Handy, 1982).

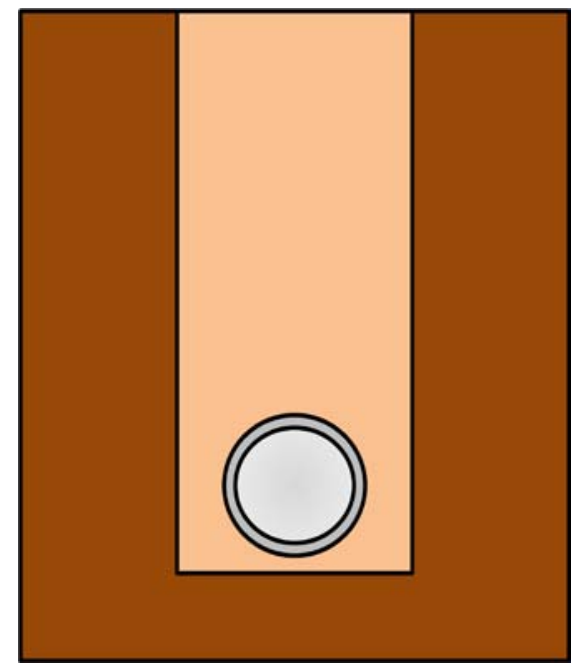

(a) Trench Construction

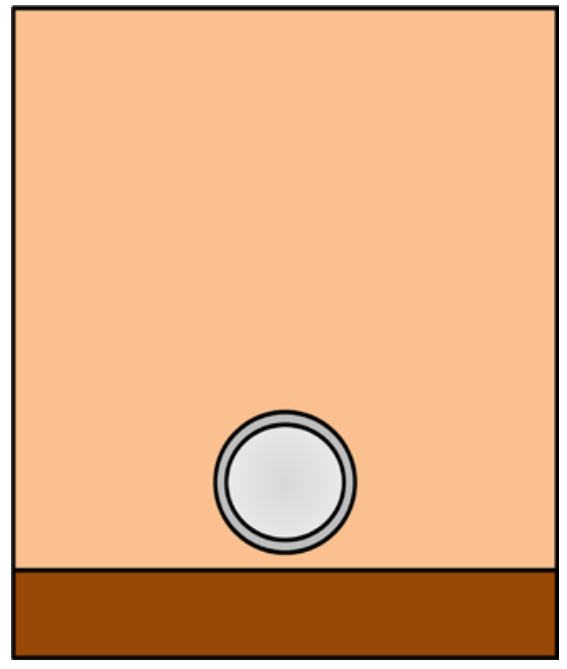

(b) Embankment Construction

Figure 1.7: Soil and pipe cross-sections under different construction methods

Various trench-width ratios, pipe diameters, pipe backfill materials, and drainage conditions are considered in the analysis. The trench-width ratio $\left(\mathrm{N}_{\mathrm{r}}\right)$ is defined as the ratio of the trench-width to the average diameter of the pipe, and the trench-width is shown in Figures 1.3 and 1.4. Granular and cohesive materials are the two different backfill materials considered in this study. Drainage boundaries are present at the soil-pipe interface and the surface. Pore pressure dissipates due to these flow boundaries, allowing soil consolidation to occur (Helwany, 2007). Figure 1.8 illustrates these boundary conditions considered in the analyses. The finite element program, ABAQUS, was used to study the long-term performance of HDPE and PVC pipes under the influence of a gravity load of the soil. 


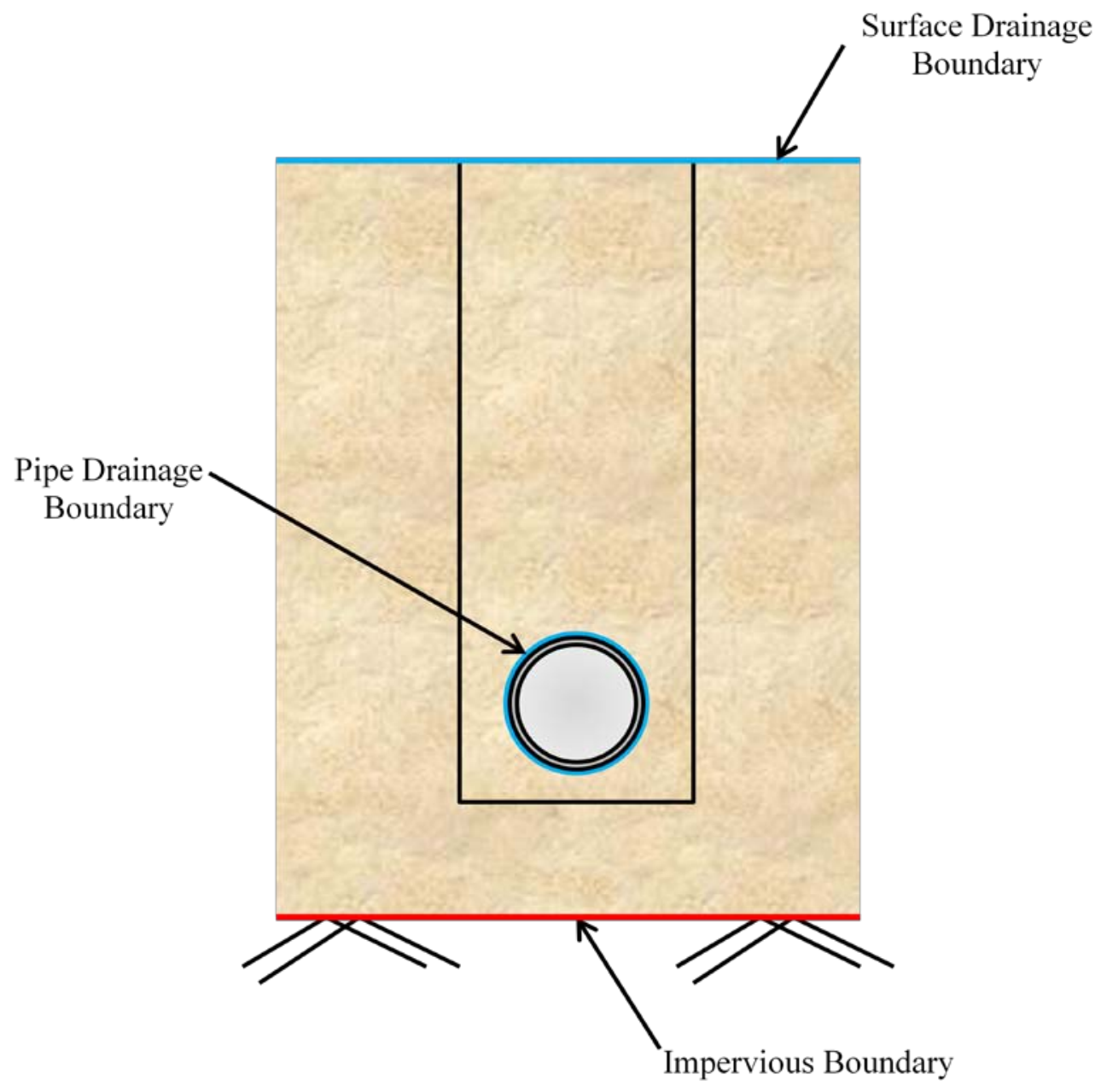

Figure 1.8: Surface drainage and soil/pipe interface drainage conditions

\subsection{Previous Studies}

There is limited literature on the performance of buried pipes under the combined conditions of soil consolidation and creep of pipe material. Many studies have been performed on the design of thermoplastic pipes (Gassman et al., 2005; Sargand et al, 2005). However, there is limited information on the long-term performance of corrugated HDPE pipes, despite the ample literature available on the material properties (Kang, 2009).

Throughout the years, finite element analysis has been used to study soil-structure interaction mechanics (Moser, 1990). Two-dimensional finite element analyses have been utilized to study the deflection of pipes and strains acting on the pipe (Dhar, 2004). Studies have 
also been done to evaluate the short-term and long-term soil-structure interactions of buried pipes using the finite element soil models (Kang, 2009; Selig, 1988).

\subsection{Scope of Work}

ABAQUS (Simulia, 2010), a commercial finite element program, was used to study the behavior of solid-wall PVC and double-wall corrugated HDPE pipes under a gravity loading. Creep of the pipe and soil consolidation acting around the pipe were the two time-dependent processes analyzed in the study. These two conditions were studied for a time period of 50 years. The scope of the study is limited to the following conditions:

- Burial Depth (Z): 10 feet, 20 feet, 30 feet, and 50 feet

- $\quad$ Trench-Width Ratio, $\mathrm{N}_{\mathrm{r}}\left(=\mathrm{W} / \mathrm{D}_{\text {avg }}\right): 1.5,2.0$, and 2.5

- HDPE Pipe Diameters: 24-inch, 36-inch, 48-inch, and 60-inch

- $\quad$ PVC Pipe Diameters: 18-inch and 24-inch

- Backfill Materials: clay and granular stone

\subsection{Research Objectives}

The primary objectives of the proposed research project are to:

- Perform a literature review to gather information on the soil-pipe interface and the effects of consolidating soil acting around a pipe;

- Investigate creep properties of a buried pipe and consolidation properties of surrounding soil;

- Consider pipes made of HDPE and PVC materials;

- Determine the effect of soil consolidation on the behavior of buried HDPE and PVC pipes under different drainage conditions;

- Analyze the long-term performance of 24-inch to 60-inch diameter double-wall corrugated HDPE pipes under two different time-dependent conditions: (a) creep and (b) creep with consolidating soil; 
- Analyze the long-term performance of 18-inch to 24-inch solid wall PVC pipes under two different time-dependent conditions: (a) creep and (b) creep with consolidating soil;

- Study the performance of HDPE and PVC pipes under different trench backfill heights, trench-width ratios, pipe backfill materials, and drainage conditions;

- Impose boundary conditions to simulate drainage at the ground surface and around the pipe;

- Study different types of construction methods under different backfill heights: 10 feet to 20 feet - trench replacement; 30 feet to 50 feet - embankment (Figure 1.7, see section 1.3)

- Compare the pipe deflections of the creep models versus the combined creep and consolidation models;

- Evaluate current specifications that pertain to this project, and propose necessary recommendations for future studies, if any. 


\section{CHAPTER 2: PERFORMANCE OF BURIED FLEXIBLE PIPES}

\subsection{Introduction}

In recent years, flexible pipes have been commonly used for drainage water conveyance due to the light weight of the material, cost efficiency, and chemical resistance (Sargand et. al., 2005). In the early years of buried pipe design, it was believed that rigid pipes, such as steel and concrete, could withstand greater loads because these materials were assumed to have greater strength. However, for most small-scale projects, thin-walled flexible pipes are more beneficial to use than rigid pipes due to the lightweight of the material, easy installation, low cost as compared to pipes made of concrete and metal, and flexible nature (Masada \& Sargand, 2007). The study presented in this report only considers flexible pipes, specifically HDPE and PVC pipes, as stated in Chapter 1.

One of the most important aspects of buried pipe design is the soil-pipe interaction (Lewis, 1998). Pipe design is usually based on the performance of the pipe material in laboratory tests (Moore \& Hu, 1996). The structural performance of a buried pipe is closely related to the nature of the surrounding soil (Gassman et al., 2005).

In this chapter, the following aspects of buried pipe design are presented:

- Factors influencing pipe performance;

- Characteristics of flexible pipes;

- $\quad$ Soil-pipe interaction;

- Soil-arching phenomenon.

\subsection{Previous Studies}

Many studies have been performed on plastic pipes (HDPE and PVC); however, there is a lack of comprehensive field performance data for large-diameter flexible pipes under real loading conditions over long periods of time (Sargand, et. al., 2005). The long-term effects of a 100-foot buried 24-inch diameter HDPE pipe have been reported in the literature (Hashash \& 
Selig, 1990). In this experiment, a crushed limestone compacted to $100 \%$ of the dry unit weight (standard Proctor test, AASHTO T-99) was used as the backfill material. It was observed that the pipe response to the backfill stabilized shortly after construction. The vertical diameter of the pipe decreased by $4.3 \%$ and the horizontal diameter increased by $0.6 \%$ (Sargand et al., 2005). The field performance of 42-inch diameter HDPE pipe under a 52-foot gravel backfill has been reported in the literature (Sargand et al., 2005). According the reported information, the horizontal deflection stabilized after about 40 days, but the vertical deflection took much longer to stabilize. The vertical soil pressure at the crown and invert decreased while the lateral soil pressure at the springline increased. It has been reported that the pipe deflected by $-10 \%$ in the vertical direction and 3\% in the horizontal direction (Sargand et. al., 2005).

It has been reported in the literature that the peaking deflections of HDPE and PVC pipes were proportional to the compaction of the backfill soil (Masada \& Sargand, 2007). Sargand et al. (2005) founded that flexible pipes experiencing peaking deflections during the initial backfilling stage are useful in minimizing the long-term pipe deflections. Peaking deflections can be expressed as a function of average pipe radius, average moist unit weight, friction angle of backfill soil, lateral pressure generated by the soil compaction, and bending stiffness of the pipe (Masada \& Sargand, 2007).

The structural behavior of a solid-wall PVC pipe buried in sand backfill influenced by a soil trench loading has been reported in the literature (Cho \& Vipulanandan, 2004). It was recorded that after 30 days of loading, the deflections in the pipe increased by $16 \%$. The deflections remained unchanged after 60 days of loading. A surface loading $\left(q_{o}\right)$ of 112 psi was applied. The vertical stress on the crown of the pipe was $0.46 q_{o}$, and the vertical stresses on the crown of the pipe remained unchanged after 60 days of loading (Cho \& Vipulanandan, 2004).

Large-diameter thermoplastic pipes are relatively new and long-term full-scale field tests are costly and labor intensive (Sargand et. al., 2005). Therefore, numerical studies such as the one presented in this report could provide useful information needed for the design of buried pipes as well as field tests. 


\subsection{Factors Influencing Pipe Performance}

The performance limit of a buried pipe is defined as its ability to handle increasing loads without deforming beyond a certain percentage (Watkins, 2000). A pipe may fail due to external soil pressures (Watkins, 2000). However, depending on the soil-pipe interaction mechanism, part of the soil weight may be supported by the surrounding insitu soil (Watkins, 2000).

Three parameters considered in buried pipe design are loading (i.e. depth of burial), soil stiffness in the pipe zone, and pipe stiffness (i.e. elastic modulus) (Moser, 1990). The overall performance of a buried pipe is highly influenced by the properties of the backfill material (Dhar, 2004). In this study, two different types of pipe backfill material were considered: granular stone and clay materials. For thermoplastic pipes, dense backfill materials provide better soil support, which can depend on the level of compaction. Common compaction practices are not sufficient enough to provide uniform compaction around the pipe, especially when a small trench-width is involved (Chu, 2010).

\subsection{Pipe Deflections}

Determining the deflection of a pipe is a very important aspect of buried pipe design. One way of calculating pipe deflection is given by Equation 2.1 (Howard, 1977), which is given below.

$$
\text { PipeDeflection }=\frac{\text { LoadOnPipe }}{\text { PipeStiffness }+ \text { SoilStiffness }}
$$

\subsubsection{Surrounding Soil}

A buried pipe's structural performance is related to the nature of the surrounding soil. The pipe and soil form a system where each type of material reacts with the other material's response. Loading on the pipe begins immediately after installation (Gassman et al., 2005). Successful performance of a pipe is based upon proper trenching, backfilling, and compaction. 
The flexible pipe will deform as the surrounding soil deforms. Failure modes in plastic pipes include (Gassman et al., 2005):

- Compression buckling in the circumferential plane (hoop compression);

- Compression buckling in the longitudinal plane;

- Local compression buckling due to point loadings.

Ring deflection and longitudinal (beam) deflection are both possible deformations of plastic pipes as shown in Figure 2.1 (Gassman et al., 2005). Improper bedding can cause compression buckling in the crown of the pipe (see crown of pipe in Figure 1.1) and also circumferential cracking below the pipe. Leaks at joints, reduction of the hydraulic capacity of the pipe, and reduction of support due to shallow cover can all be results of excessive pipe deflection (Gassman et al., 2005).

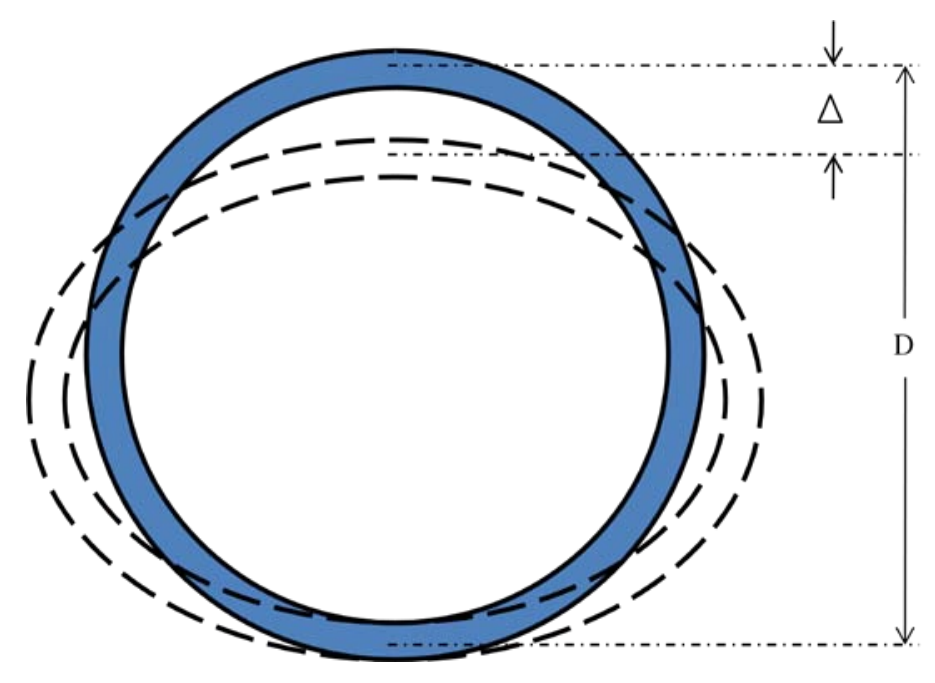

Figure 2.1: Illustration of ring deflection

\subsubsection{Parallel Plate Loading Test}

The parallel plate loading method (ASTM Standards, D 2412) is a standardized test for evaluating the bending stiffness and strength of thermoplastic pipes (McGrath \& Shafer, 2003). A schematic diagram of the parallel load test is shown in Figure 2.2. AASHTO M294 uses the 
test to ensure that corrugated HDPE pipe has a minimum pipe stiffness at $5 \%$ deflection (McGrath \& Shafer, 2003).

Laboratory tests and field performance are important aspects for buried pipe design. Parallel plate loading tests and hoop compression tests are performed to evaluate the effective modulus, pipe stiffness, stress relaxation, and creep of polyethylene pipes (Moore \& Hu, 1996; McGrath \& Shafer, 2003). A loading rate of $12 \mathrm{~mm} / \mathrm{min}$ is used in the parallel plate loading test, and the load is divided by the vertical deflection, defining pipe stiffness at $5 \%$ vertical deflection (Moore \& Zhang, 1998; McGrath \& Shafer, 2003). Pipe stiffness can be expressed by the following parameters (Moser, 1990):

$$
\begin{aligned}
& \text { Stiffness factor }=\mathrm{EI} \\
& \text { Ring stiffness }=\mathrm{EI} / \mathrm{r}^{3}
\end{aligned}
$$

$$
\text { Pipe stiffness }=6.7 \mathrm{EI} / \mathrm{r}^{3}
$$

where

$$
\begin{aligned}
& E=\text { modulus of elasticity }\left(\mathrm{lb} / \mathrm{in}^{2}\right) \\
& \left.\mathrm{I}=\text { moment of inertia of the wall cross-section per unit length of pipe (in }{ }^{4} / \mathrm{in}\right) \\
& \mathrm{r}=\text { mean radius of pipe (in) }
\end{aligned}
$$

Pipe stiffness can also be expressed as (Moser, 1990):

$$
P S_{f}=\frac{F}{\delta_{v}}=\frac{6.7 E I}{r^{3}}
$$

where

$$
\begin{aligned}
& \mathrm{PS}_{\mathrm{f}}=\text { pipe stiffness (psi) } \\
& \mathrm{E}=\text { modulus of elasticity (psi) } \\
& \mathrm{I}=\text { moment of inertia of the pipe wall (in } / \text { in) }
\end{aligned}
$$




$$
\begin{aligned}
& r=\text { mean radius (in) } \\
& F=\text { force applied over unit length (lbs) } \\
& \delta_{\mathrm{v}}=\text { vertical change in the pipe diameter (in) } \\
& \delta_{\mathrm{v}}=\text { vertical change in the pipe diameter (in) }
\end{aligned}
$$

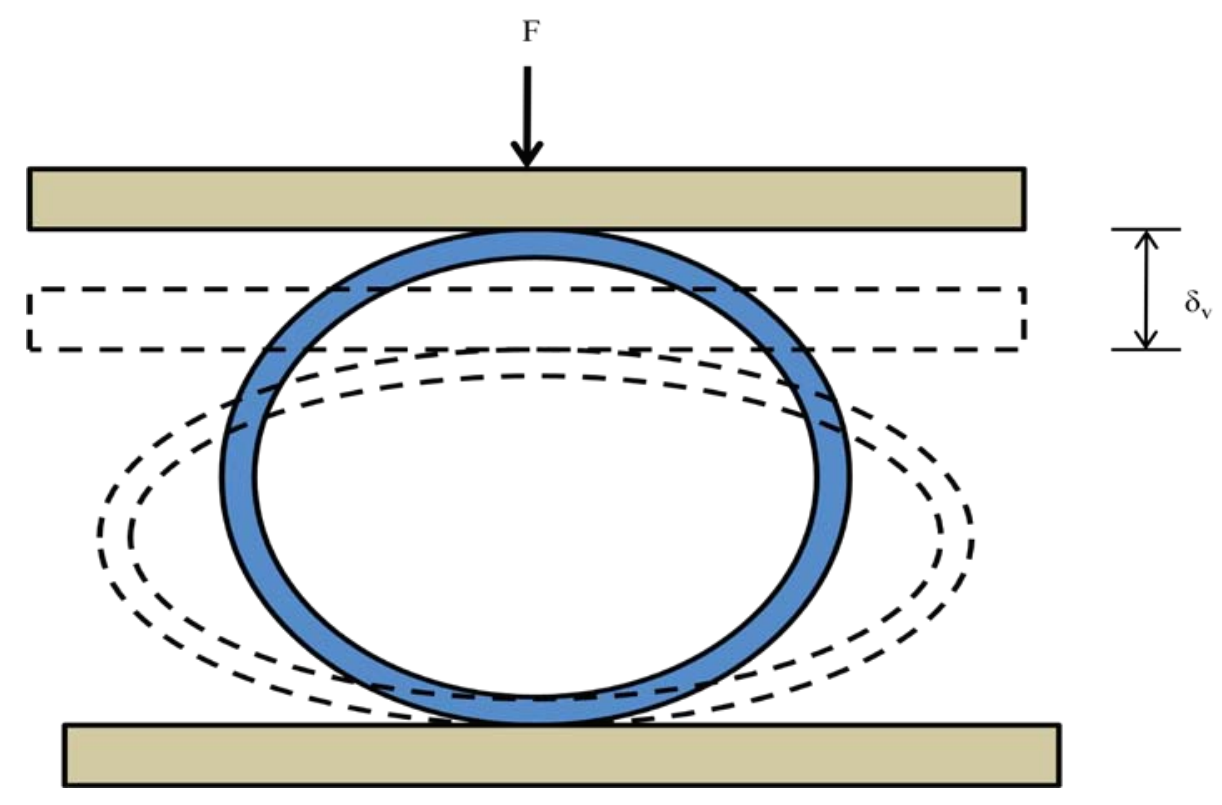

Figure 2.2: Parallel plate testing (ASTM 2412 Test) for flexible pipes

\subsection{Soil Stiffness}

Performance of a buried pipe is highly influenced by the strength of the soil surrounding the pipe. Soil compaction and soil type contributes to the performance of a buried pipe, and the soil envelope around the pipe is extremely important (Moser, 1990). Aspects of the soil-pipe interaction and the calculations involved in order to predict the relationship between the pipe and soil are discussed in the following section. 


\subsubsection{Spangler's Iowa Formula}

Spangler (1941) recognized that flexible pipes perform well when buried in soil, despite their lower stiffness as compared to rigid pipes (Moser, 1990). The redistribution of loads around the pipe and the passive pressures created when the sides of the pipe move outwards in the soil allow the flexible pipe to support vertical loadings (Moser, 1990).

In 1941, Spangler published his work incorporating the effects of surrounding soil on the deflection of a pipe (Moser, 1990). It was assumed that Marston's theory of loads was applicable and the soil load was uniformly distributed (Moser, 1990). The horizontal pressure $h$ on each side of the pipe would be proportional to the deflection of the pipe into the soil. The elastic modulus of the soil was considered to be constant. Figure 2.3 illustrates the basis of the derivation of the Iowa formula (Spangler, 1941) for the deflection of buried pipes. The Iowa formula (Spangler, 1941) was then derived as shown below:

$$
\Delta X=\frac{D_{L} K W_{c} r^{3}}{E I+0.061 e r^{4}}
$$

where

$$
\begin{aligned}
& \mathrm{D}_{\mathrm{L}}=\text { deflection lag factor } \\
& \mathrm{K}=\text { bedding constant } \\
& \mathrm{W}_{\mathrm{C}}=\text { Marston's load per unit length of pipe (lb/in) } \\
& \mathrm{r}=\text { mean radius of the pipe (in) } \\
& \mathrm{E}=\text { modulus of elasticity of the pipe material }\left(\mathrm{lb} / \mathrm{in}^{2}\right) \\
& \mathrm{I}=\text { moment of inertia of the pipe wall per unit length }\left(\mathrm{in}^{4} / \mathrm{in}\right) \\
& \mathrm{e}=\text { modulus of passive resistance of the side fill }\left[\mathrm{lb} /\left(\mathrm{in}^{2}\right)(\mathrm{in})\right] \\
& \Delta \mathrm{X}=\text { horizontal deflection or change in diameter }(\mathrm{in})
\end{aligned}
$$



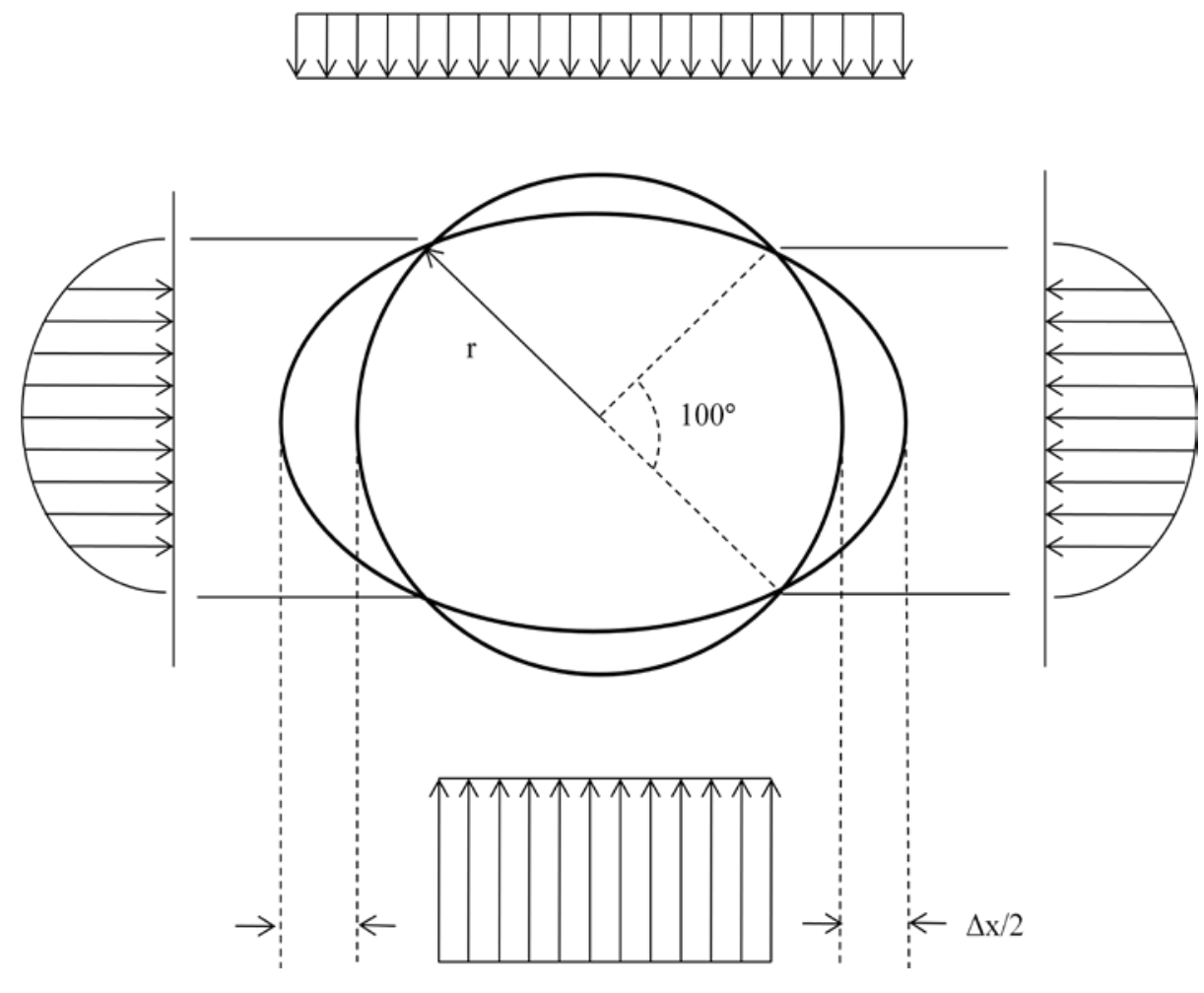

Figure 2.3: Basis of Spangler's derivation of the Iowa formula for deflection of buried pipes (Moser, 1990)

\subsubsection{Deflection Lag Factor}

The deflection lag factor, $D_{L}$, is also needed to calculate pipe deflections. Spangler (Spangler, 1941) noted that soil consolidation at the sides of the pipe continues with time after installation of the pipe. Deflections could increase by as much as $30 \%$ over a time period of 40 years due to soil consolidation (Moser, 1990). In order to consider this increase in deflection, the deflection lag factor was incorporated. The value used for this factor is 1.5 as a conservative approach (Moser, 1990). 


\subsubsection{Modulus of Soil Reaction}

The stiffness of a soil is characterized by its modulus of soil reaction, $E$ '. This modulus increases with depth as discussed in the literature (Hartley \& Duncan, 1987). The Iowa formula is the most common formula used to calculate deflections for design purposes (Moser, 1990). However, the use of $E$ ' introduces a large degree of uncertainty due to its empirical nature (Hartley \& Duncan, 1987). E' is similar to a soil modulus (Young's Modulus) and behaves in the same manner (Hartley \& Duncan, 1987). Three procedures on how to calculate $E$ ' can be found in the literature (Hartley \& Duncan, 1987).

The use of $E$ ' values as well as a simplified method of calculating the backfill load on a pipe can somewhat predict the initial deflection of a flexible pipe under backfill heights up to 50 feet. A pipe's vertical diameter decreases and its horizontal diameter increases due to overbearing loads (Howard, 1977; Moser, 1990). The strain or deformation of an element can be determined from the ratio of the load or stress on the member to its modulus of elasticity (Howard, 1977).

\subsection{Magnitude of Loads}

The ability of a buried pipe to support the vertical load caused by the overbearing soil is an extremely important aspect of buried pipe design. This support of the vertical soil load is based upon the redistribution of loads to the surrounding soil, as well as the passive pressure caused by the pipe moving outward into the soil (Moser, 1990). The development of passive soil support at the sides of the pipe is caused by the pipe deflection (Spangler \& Handy, 1982).

\subsubsection{Gravity Loading (Geostatic Loading)}

Gravity load throughout the soil is introduced in the soil model during the first step of the analysis, which is the geostatic step. The geostatic step ensures that the loads and initial stresses are in equilibrium and produce zero deformations (Helwany, 2007). 


\subsubsection{Pore Pressure}

The self-weight of the soil causes pressures to be placed on the buried pipe. These overburden soil pressures are the main cause of the creep of the pipe. When a load acts on a pipe buried in saturated soil, an increase in pore pressure around the pipe occurs (Helwany, 2007). Due to pore pressure development around the pipe, the soil undergoes consolidation, which can potentially cause additional loads onto the pipe (Lewis, 1998). In this study, both the creep response and soil consolidation were considered in determining time-dependent pipe deflections.

\subsubsection{Soil Arching}

Soil arching is the phenomenon that occurs when part of the weight of the soil is transferred between the soil prism over the conduit (Figure 2.4) and adjacent soil prisms (Spangler, 1994). The load acting on the pipe can be greater than the total weight of the overlying soil plus the surface loads, causing negative arching, as seen in Figure 2.5 (b). Positive arching occurs when the load acting on the pipe is significantly less than the combined surface load and overburden soils weight as shown in Figure 2.5 (a) (Spangler \& Handy, 1982). Depending upon the stiffness of the soil and pipe properties, the arching mechanism may contribute to the external load on a pipe. The magnitude of pipe deflections and pipe stresses depend on the external loads and soil-pipe interactions. The design of corrugated HDPE pipes is based upon deflections and wall stresses (Kang et al., 2009). 


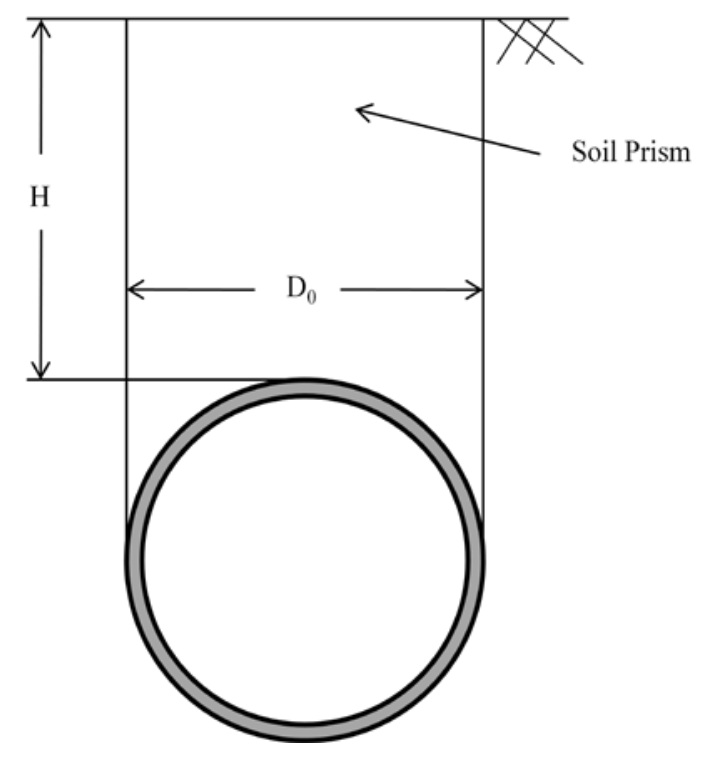

Figure 2.4: Schematic of soil prism over conduit

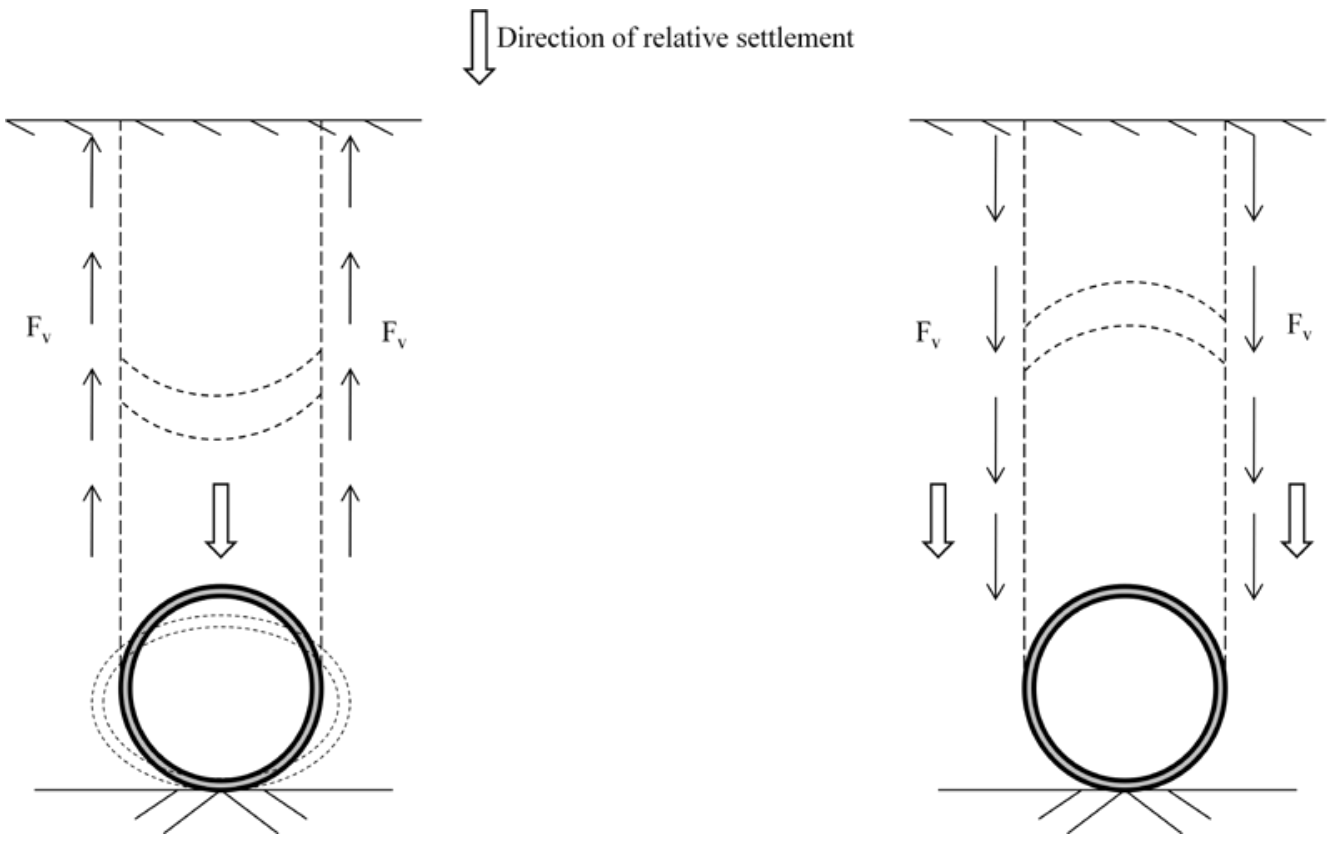

(Note: $F_{v}=$ generated friction forces)

(a)

(b)

(a) Thermoplastic pipe in embankment installation

(b) Rigid pipe in embankment installation (interface condition, full-bonded)

Figure 2.5: Mechanism of soil arching within soil-pipe system (Kang, 2009) 


\subsection{External Soil Loadings}

This study considers the following loadings: (a) trench backfill loading and (b) embankment loading. Trench backfill loads are considered for backfill heights of 10 feet to 20 feet. A trench loading can be seen in Figure 2.6. Embankment loading is considered for backfill heights greater than 30 feet, and an embankment loading can be seen in Figure 2.7. In both trench and embankment loadings, it takes time for the full load to mobilize on the pipe depending upon time-dependent properties of the pipe (Moser, 1990).

\subsubsection{Trench Loading}

In this study, trench loading is considered for backfill heights of 10 feet to 20 feet, representing a ditch conduit (Spangler, 1958). The forces on the buried structure will be less than those caused by embankment loading. Trench installation method is common for shallow conduits (Spangler \& Handy, 1982). When a trench backfill is placed over a pipe, a large portion of the weight of that soil is supported by shear forces (see Figure 2.6) acting along the backfill at the contact surface of the native soil (Spangler, 1958). In this study, it was assumed that no friction exists between the trench backfill and insitu soil, causing the entire weight of the backfill to be placed on the pipe, as seen in Figure 2.6. This would be the worst-case scenario of trench backfill loading.

\subsubsection{Embankment Loading}

In this study, embankment loading is applied for fill heights of 30 feet to 50 feet, and the soil loading can be seen in Figure 2.7. The worst case scenario for a buried pipe is to construct an embankment over the pipe (Watkins, 2000). Pipes placed under embankment loadings are referred to as projecting conduits (Spangler, 1958; Spangler \& Handy, 1982). This method is the easiest to construct, but the loads acting on the conduit could potentially be greater than the weight of the overlying soil (Spangler, 1958). 


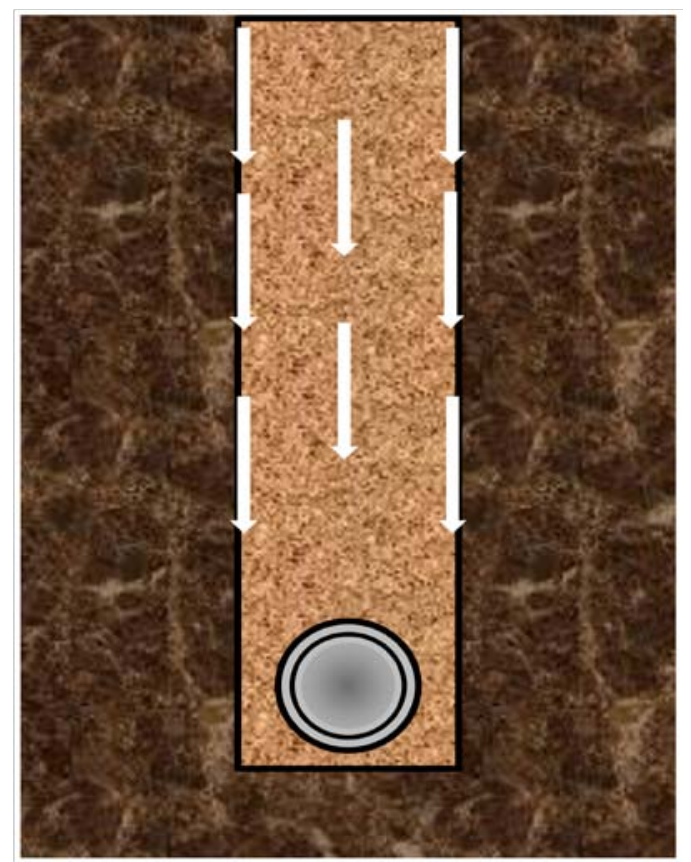

Figure 2.6: Trench backfill loading

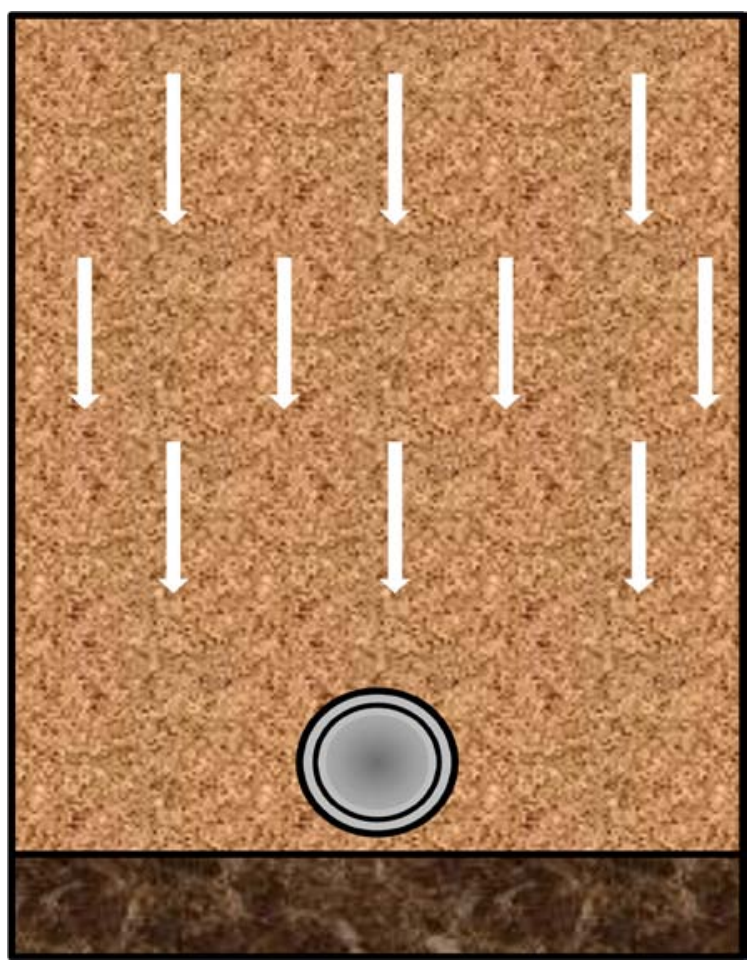

Figure 2.7: Embankment loading 


\subsection{Soil-Pipe Interaction}

The performance of a flexible pipe depends on the composite action between the pipe and backfill soil. It is important for this system to achieve structural stability. Proper installation of flexible pipes is extremely important so that the structural performance is not compromised (Chu, 2010).

The soil-pipe interaction depends on the pipe properties, soil type, moisture content, soil density, and depth of installation (Moser, 1990). Pipe performance is highly affected by this interaction, and the interaction between the pipe and soil is a function of pipe and soil properties (Moser, 1990). The soil-pipe system is quite complex and is statically indeterminate (Lewis, 1998).

Granular and clay backfill materials are considered in this study. Granular material is commonly used as bedding for flexible pipes because this material is self-compacting. It also reduces the stress acting on the wall of the pipe. The modulus of soil reaction of granular material considered in this study is higher than that of the insitu soil, which results in the ability to carry greater loads without deforming the pipe (Chu, 2010). When the insitu soil is in poor condition, adequate lateral support is not provided when the flexible pipe deforms vertically and horizontally. This results in the need of additional trench-width so additional bedding material can be placed (Chu, 2010). 


\section{CHAPTER 3: TIME DEPENDENT PROPERTIES OF PIPE AND BACKFILL}

\subsection{Background of HDPE pipes}

High-density polyethylene (HDPE) pipes are made of a lightweight material, allowing for easier installation as compared to rigid pipes (Zhang, 1998). HDPE pipes are flexible, durable, and are effective in managing water transportation. The American Association of State Highway and Transportation (AASHTO M294, 2007) has classified available polyethylene pipes. In the study presented in this report, double-wall corrugated pipes were considered. A typical doublewall corrugated pipe consists of a circular cross-section with a corrugated outer surface and a smooth inner surface. The outer corrugations provide superior structural integrity, and the smooth inner surface provides excellent pipe flow (ADS, 2006). Figure 3.1 (a) shows a schematic diagram of a double-wall corrugated HDPE pipe and Figure 3.1 (b) shows a crosssection of the pipe. Pipe diameters ranging between 24-inch to 60-inch are the focus of this study.

\subsection{Background of PVC Pipes}

PVC is flexible, easy to handle, lightweight, and resistant to chemical damage and corrosion (CertainTeed, 2008). Gravity pipes made of PVC are used to serve sanitary sewers, storm sewers, and highway drainage applications (CertainTeed, 2008). Two types of gravity PVC pipes include solid-wall pipes and profile-wall pipes. Solid-wall PVC pipes are the focus of the study. These pipes are manufactured as per ASTM D3034 and F679 standards (Diamond Plastics, 2005). The inner and outer surfaces are smooth and the wall thickness is uniform. These solid-wall pipes are used for pressure and non-pressure applications. 


\subsection{Introduction to Time-Dependent Behavior of Pipes}

It is important to understand the effects of creep on buried pipes made of HDPE and PVC materials. Thermoplastic materials such as HDPE and PVC possess the time-dependent property of creep. Creep is defined as the increase of strain in a material caused by a constant applied load over a period of time (Moser, 1990; Arvidsson \& Gronvall, 2004). Creep of a material could result in failure over time. Therefore, understanding creep, as well as stress relaxation and visco-elastic behavior of thermoplastic materials, is an important aspect of buried pipe design.

In the following sections, creep, stress relaxation, and the power law models used for PVC and HDPE will be discussed. The sectional properties of double-corrugated HDPE pipes and solid-wall PVC pipes will also be discussed.

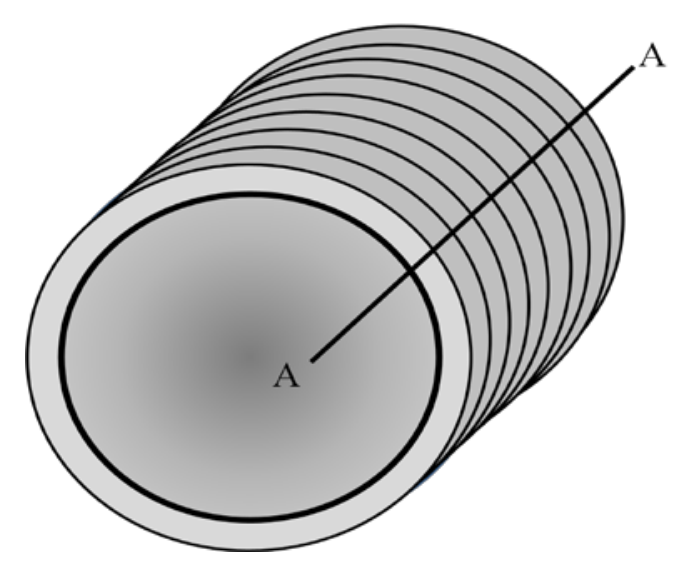

(a) Schematic of a double-wall corrugated HDPE pipe (Gondle, 2008)

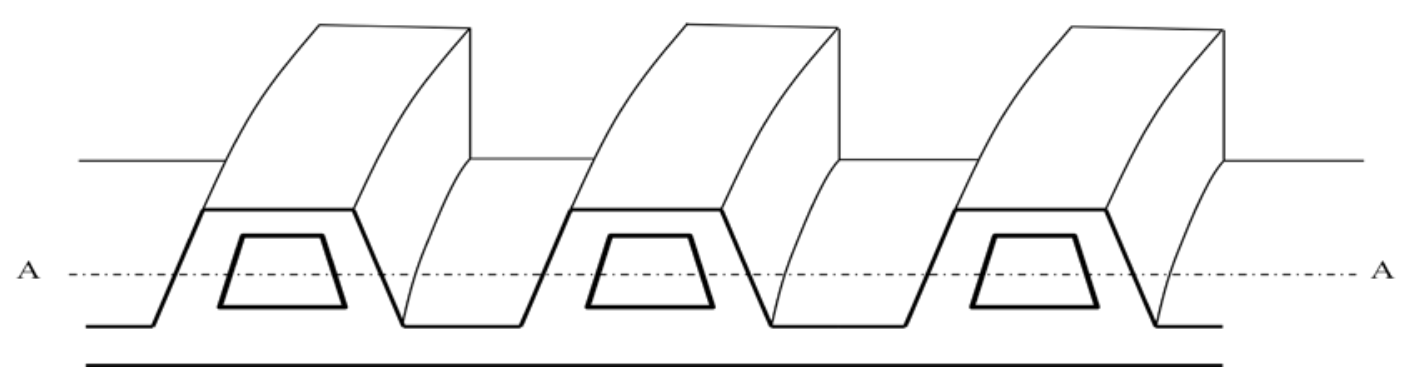

(b) Section of A-A of a double-wall corrugated HDPE pipe (Gondle, 2008)

Figure 3.1: Typical Double-wall corrugated HDPE pipe 


\subsubsection{Creep Behavior of Pipes}

Creep is defined as the continuous deformation that a material undergoes when subjected to a constant load (Moser, 1990; Arvidsson \& Gronvall, 2004). The parameters of creep include stress, strain, and time (Hult, 1966; Somoyaji, 2001). The total strain at a given time can be expressed as (Horvath, 1998):

$$
\varepsilon=\varepsilon_{o}+\varepsilon_{c}
$$

where

$$
\begin{aligned}
& \varepsilon=\text { total strain at some time } t \text { after application of stress } \\
& \varepsilon_{c}=\text { the time-dependent component (creep) of strain at time } t \text { after application of stress } \\
& \varepsilon_{o}=\text { the immediate strain of an application of stress }
\end{aligned}
$$

In a usual creep test, a tensile test specimen is subjected to a constant tensile force at a fixed temperature. The strain is recorded, and a strain versus time graph is created, as shown in Figure 3.2. A strain rate versus time graph can also be seen in Figure 3.2. The engineering theory of creep is based on idealized materials with well-defined creep properties (Hult, 1966, Arvidsson \& Gronvall, 2004).

As shown in Figure 3.1, primary creep occurs when the creep rate is decreasing, secondary creep occurs at a constant creep rate, and tertiary creep occurs when the creep rate increases subsequently (Hult, 1966; Callister, 1991). At the beginning of the initial loading, the creep rate is very high. Because the initial creep rate is high, the strain developed during the loading may differ from the strain at the instantaneous loading (Hult, 1966; Somoyaji, 2001). The strain developed during secondary creep is large compared with the strain developed during primary creep. This is true for many materials. 
The time-dependent modulus or creep modulus for a linear visco-elastic material can be expressed as seen in the following equation (Arvidsson \& Gronvall, 2004; Callister, 1991):

$$
E(t)=\frac{\sigma}{\varepsilon(t)}
$$

where

$$
\begin{aligned}
& E(t)=\text { Young's Modulus } \\
& \sigma(t)=\text { stress } \\
& \varepsilon(t)=\text { strain }
\end{aligned}
$$

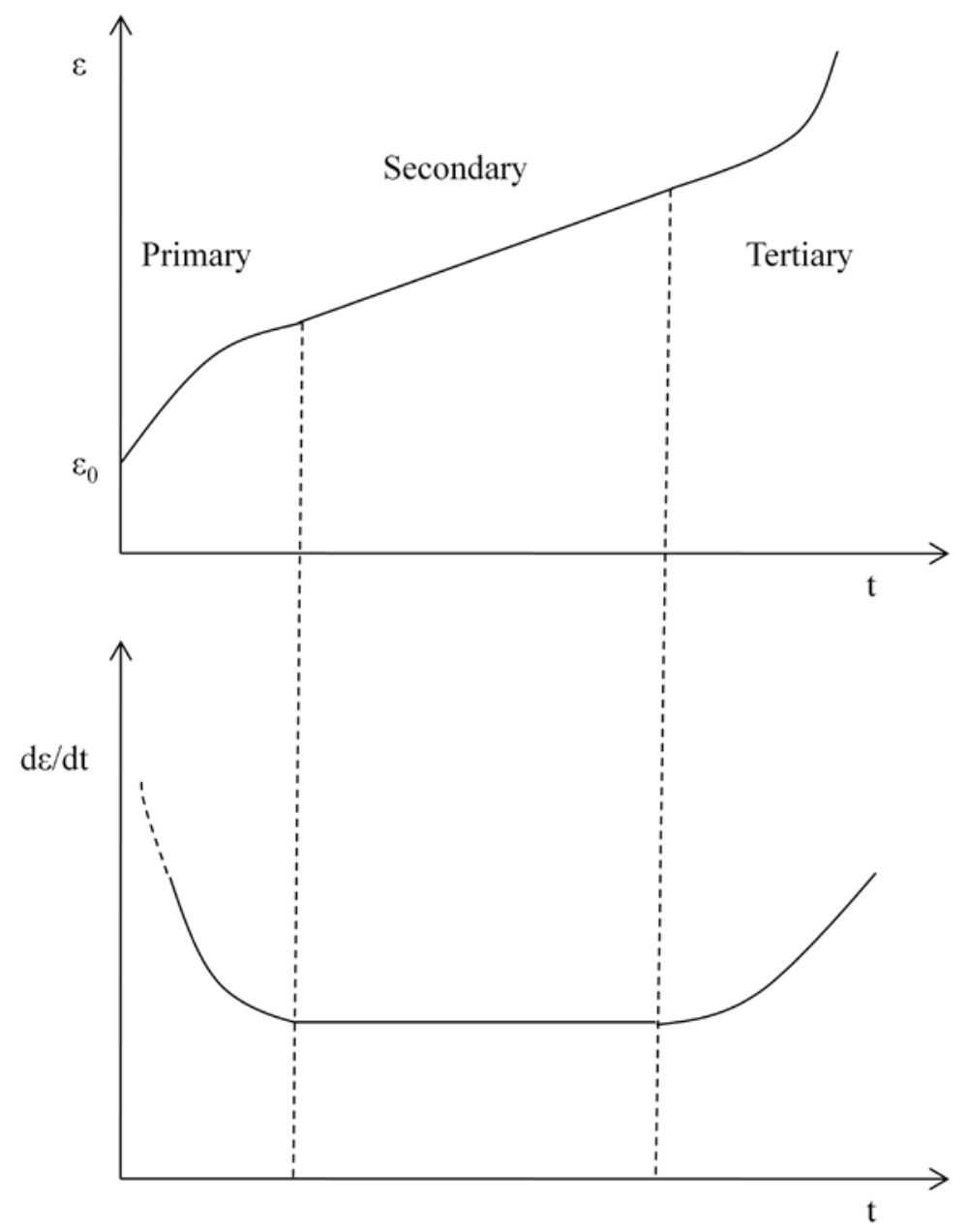

Figure 3.2: Graphs from strain and strain rate due to constant stress creep test (Hult, 1966) 


\subsubsection{Stress Relaxation of Pipes}

Stress relaxation is the inverse of creep (Arvidsson \& Gronvall, 2004), and can be defined as the decrease in stress with time in a material held at constant deformation (Moser, 1990). Stress relaxation occurs when a tensile stress decreases with time if the deflection of a material is to be kept constant (Somayaji, 2001; Callister, 1991; Moser, 1990; Hult, 1966).

In a typical stress-relaxation test, an instantaneous elongation $(\delta)$ is applied to a stressfree bar of length $L$ and cross-sectional area $A$, as seen in Figure 3.3. While $\delta$ will increase with time in a creep test, the $\delta$ is kept constant in a stress-relaxation test, which will cause the axial load $(P)$ to decrease with time (Hult, 1966, Callister, 1991).

L

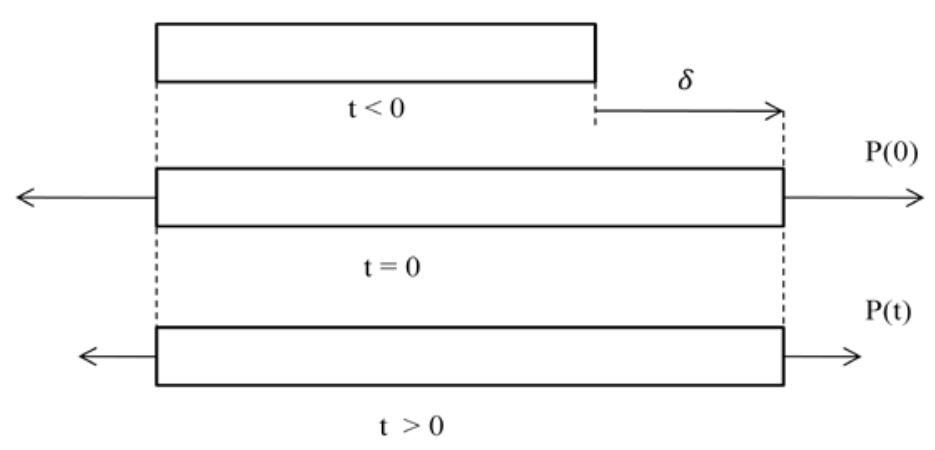

Figure 3.3: Constant strain loading (Hult, 1966)

\subsection{Power Law Models for Pipes}

Power law models have been used to simulate creep behavior in various applications, including buried pipes. A number of power law models can be used to simulate creep behavior of a plastic pipe (Pertroff, 1993; Hashash, 1991; Chua, 1986; and Janson, 1985). The power law models for HDPE and PVC pipes are discussed in the following section. 


\subsubsection{Power Law Models for HDPE Pipes}

Several models have been proposed based on the creep behavior of HDPE pipes (Moore, 1995; Hashash, 1991; Chua, 1986; and Janson, 1985). Previous studies (Gondle, 2006) have shown that the creep model proposed by Hashash (1991) for HDPE pipes provide conservative results on the long-term performance. The following relationship has been reported on the basis of laboratory test results (Hashash, 1991).

$$
E(t)=96,300 t^{-0.0859}
$$

where $E(t)$ is expressed in psi and $t$ is given in minutes.

This equation can be expressed in different units as:

$$
E(t)=51,586.38 t^{-0.0859}
$$

where $E(t)$ is expressed in psi and $t$ is measured in days. This equation was used in the modeling study presented in this report.

Equation 3.3 can be used to compute the modulus value at 50 years. The computed value is very close to the AASHTO recommended 50-year modulus value of 22,000 psi (AASHTO, 2002).

\subsubsection{Power Law Models for PVC Pipes}

Stress relaxation tests were performed on PVC pipes and the relaxation modulus as a function of loading time over 10,000 hours was presented in the literature (Janson, 1985). The following power law model was developed (Janson, 1995):

$$
E(t)=394,043 t^{-0.0567}
$$


where $E(t)$ is expressed in psi and $t$ is given in hours. This equation can be expressed in different units as:

$$
E(t)=329,067.99 t^{-0.0567}
$$

where $E(t)$ is expressed in psi and $t$ is measured in days. This equation was used in the modeling study presented in this report.

\subsection{Properties of Double-wall Corrugated HDPE Pipes}

In this section, the geometric and material details of double-wall corrugated pipes will be discussed. The section properties of dual-walled corrugated HDPE pipes are shown in Table 3.1.

\subsubsection{Geometric and Material Details of Double-wall Corrugated HDPE Pipes}

In this section, details of the procedure used in modeling of HDPE corrugated pipes are presented. Though the pipe sizes from 24-inch to 60-inch were considered in the study, this section presents numerical details only for a 24-inch pipe. The numerical procedure for all other pipe sizes is similar to what is presented below.

For a 24-inch nominal pipe diameter:

$$
\begin{aligned}
& \text { Minimum pipe stiffness @ 5\% deflection (K) = } 34 \mathrm{psi}\left(235 \mathrm{kN} / \mathrm{m}^{2}\right) \\
& \text { Inside Diameter (ID) = } 24.08 \text { in }(611 \mathrm{~mm}) \\
& \text { Outside diameter (OD) } \quad=27.80 \text { in }(706 \mathrm{~mm}) \\
& \text { Moment of inertia }\left(\mathrm{I}_{\mathrm{d}}\right) \quad=0.137 \mathrm{in}^{4} / \mathrm{in} \\
& \text { Distance from inner wall to neutral axis (C) } \quad=0.74 \text { in }(18.8 \mathrm{~mm}) \\
& \text { Flexural modulus of the pipe }\left(E_{d}\right) \quad=110,000 \mathrm{psi}\left(758,423 \mathrm{kN} / \mathrm{m}^{2}\right) \\
& \text { Mean diameter }\left(D_{\text {mean }}\right)=\text { Inside diameter }(I D)+2 C \\
& =24.08+2(0.74)=25.56 \text { in }
\end{aligned}
$$


Table 3.1: Section properties of dual-wall corrugated HDPE pipes (ADS Inc., 2006)

\begin{tabular}{|c|c|c|c|c|c|c|c|c|}
\hline $\begin{array}{l}\text { Nominal } \\
\text { Diameter }\end{array}$ & $\begin{array}{l}\text { Inside } \\
\text { Diameter }\end{array}$ & $\begin{array}{l}\text { Outside } \\
\text { Diameter } \\
\text { Average }\end{array}$ & $\begin{array}{l}\text { Inner Liner } \\
\text { Thickness, } \\
\text { Minimum }\end{array}$ & $\begin{array}{c}\text { Minimum Pipe } \\
\text { Stiffness at 5\% } \\
\text { Deflection }\end{array}$ & $\begin{array}{l}\text { Weight } \\
\text { Lbs/20ft } \\
\text { (kg./6m) }\end{array}$ & $\begin{array}{l}\text { Area } \\
\text { in }^{2} / \text { in }\end{array}$ & $\begin{array}{c}\text { "I" } \\
\text { in /in }\end{array}$ & $\begin{array}{l}\text { "C" } \\
\text { in }\end{array}$ \\
\hline $\begin{array}{c}6 ” \\
(150 \mathrm{~mm})\end{array}$ & $\begin{array}{c}6.00 ” \\
(152 \mathrm{~mm})\end{array}$ & $\begin{array}{c}6.92 ” \\
(176 \mathrm{~mm})\end{array}$ & $\begin{array}{c}0.020 ” \\
(0.5 \mathrm{~mm})\end{array}$ & $\begin{array}{c}50 \mathrm{psi} \\
340 \mathrm{kN} / \mathrm{m}^{2}\end{array}$ & $\begin{array}{l}17.00 \mathrm{lbs} \\
(7.71 \mathrm{~kg})\end{array}$ & $\begin{array}{c}0.085 \\
2 \\
\left(2.15 \mathrm{~mm}^{2} / \mathrm{mm}\right)\end{array}$ & $\begin{array}{c}0.0021 \\
(0.035 \mathrm{~cm} / \mathrm{cm})\end{array}$ & $\begin{array}{c}0.19 \\
(4.94 \mathrm{~mm})\end{array}$ \\
\hline $\begin{array}{c}\text { 8” } \\
(200 \mathrm{~mm})\end{array}$ & $\begin{array}{c}7.90 ” \\
(200 \mathrm{~mm})\end{array}$ & $\begin{array}{c}9.11^{”} \\
(233 \mathrm{~mm})\end{array}$ & $\begin{array}{c}0.024 ” \\
(0.6 \mathrm{~mm})\end{array}$ & $\begin{array}{c}50 \mathrm{psi} \\
340 \mathrm{kN} / \mathrm{m}^{2}\end{array}$ & $\begin{array}{l}30.80 \mathrm{lbs} \\
(13.97 \mathrm{~kg})\end{array}$ & $\begin{array}{c}0.108 \\
\left(2.75 \mathrm{~mm}^{2} / \mathrm{mm}\right)\end{array}$ & $\begin{array}{c}0.005 \\
(0.078 \mathrm{~cm} / \mathrm{cm})\end{array}$ & $\begin{array}{c}0.25 \\
(6.36 \mathrm{~mm})\end{array}$ \\
\hline $\begin{array}{c}10 ” \\
(250 \mathrm{~mm})\end{array}$ & $\begin{array}{c}9.90 ” \\
(251 \mathrm{~mm})\end{array}$ & $\begin{array}{c}11.36 ” \\
(287 \mathrm{~mm})\end{array}$ & $\begin{array}{c}0.024 ” \\
(0.6 \mathrm{~mm})\end{array}$ & $\begin{array}{c}50 \mathrm{psi} \\
340 \mathrm{kN} / \mathrm{m}^{2}\end{array}$ & $\begin{array}{l}46.20 \mathrm{lbs} \\
(20.96 \mathrm{~kg})\end{array}$ & $\begin{array}{c}0.137 \\
\left(3.48 \mathrm{~mm}^{2} / \mathrm{mm}\right)\end{array}$ & $\begin{array}{c}0.008 \\
(0.134 \mathrm{~cm} / \mathrm{cm})\end{array}$ & $\begin{array}{c}0.30 \\
(7.58 \mathrm{~mm})\end{array}$ \\
\hline $\begin{array}{c}12 ” \\
(375 \mathrm{~mm})\end{array}$ & $\begin{array}{c}12.15 ” \\
(308 \mathrm{~mm})\end{array}$ & $\begin{array}{c}14.45 ” \\
(367 \mathrm{~mm})\end{array}$ & $\begin{array}{c}0.035 ” \\
(0.9 \mathrm{~mm})\end{array}$ & $\begin{array}{c}50 \mathrm{psi} \\
345 \mathrm{kN} / \mathrm{m}^{2}\end{array}$ & $\begin{array}{l}65.20 \mathrm{lbs} \\
(29.60 \mathrm{~kg})\end{array}$ & $\begin{array}{c}0.217 \\
(5.5 \mathrm{~mm} / \mathrm{mm})\end{array}$ & $\begin{array}{c}0.035 \\
(0.574 \mathrm{~cm} / \mathrm{cm})\end{array}$ & $\begin{array}{c}0.43 \\
(10.92 \mathrm{~mm})\end{array}$ \\
\hline $\begin{array}{c}15 ” \\
(375 \mathrm{~mm})\end{array}$ & $\begin{array}{c}14.98 ” \\
(380 \mathrm{~mm})\end{array}$ & $\begin{array}{c}17.57 ” \\
(448 \mathrm{~mm})\end{array}$ & $\begin{array}{c}0.039 ” \\
(1.0 \mathrm{~mm})\end{array}$ & $\begin{array}{c}42 \mathrm{psi} \\
290 \mathrm{kN} / \mathrm{m}^{2}\end{array}$ & $\begin{array}{l}92.50 \mathrm{lbs} \\
(42.00 \mathrm{~kg})\end{array}$ & $\begin{array}{c}0.272 \\
\left(6.91 \mathrm{~mm}^{2} / \mathrm{mm}\right)\end{array}$ & $\begin{array}{c}0.055 \\
(0.901 \mathrm{~cm} / \mathrm{cm})\end{array}$ & $\begin{array}{c}0.52 \\
(13.21 \mathrm{~mm})\end{array}$ \\
\hline $\begin{array}{c}18 ” \\
(450 \mathrm{~mm})\end{array}$ & $\begin{array}{c}\text { 18.07” } \\
(459 \mathrm{~mm})\end{array}$ & $\begin{array}{c}21.20 ” \\
(536 \mathrm{~mm})\end{array}$ & $\begin{array}{c}0.051 ” \\
(1.3 \mathrm{~mm})\end{array}$ & $\begin{array}{c}40 \mathrm{psi} \\
275 \mathrm{kN} / \mathrm{m}^{2}\end{array}$ & $\begin{array}{l}128.60 \mathrm{lbs} \\
(58.38 \mathrm{~kg})\end{array}$ & $\begin{array}{c}0.273 \\
\left(6.93 \mathrm{~mm}^{2} / \mathrm{mm}\right)\end{array}$ & $\begin{array}{c}0.081 \\
(1.327 \mathrm{~cm} / \mathrm{cm})\end{array}$ & $\begin{array}{c}0.057 \\
(14.48 \mathrm{~mm})\end{array}$ \\
\hline $\begin{array}{c}24 ” \\
(600 \mathrm{~mm})\end{array}$ & $\begin{array}{c}24.08 ” \\
(612 \mathrm{~mm})\end{array}$ & $\begin{array}{c}27.80 ” \\
(719 \mathrm{~mm})\end{array}$ & $\begin{array}{c}0.059 ” \\
(1.5 \mathrm{~mm})\end{array}$ & $\begin{array}{c}34 \mathrm{psi} \\
235 \mathrm{kN} / \mathrm{m}^{2}\end{array}$ & $\begin{array}{l}220.30 \mathrm{lbs} \\
(99.93 \mathrm{~kg})\end{array}$ & $\begin{array}{c}0.324 \\
\left(8.23 \mathrm{~mm}^{2} / \mathrm{mm}\right)\end{array}$ & $\begin{array}{c}0.137 \\
(2.245 \mathrm{~cm} / \mathrm{cm})\end{array}$ & $\begin{array}{c}0.74 \\
(18.8 \mathrm{~mm})\end{array}$ \\
\hline $\begin{array}{c}30 ” \\
(750 \mathrm{~mm})\end{array}$ & $\begin{array}{c}30.00 ” \\
(762 \mathrm{~mm})\end{array}$ & $\begin{array}{c}35.10 ” \\
(892 \mathrm{~mm})\end{array}$ & $\begin{array}{c}0.059 ” \\
(1.5 \mathrm{~mm})\end{array}$ & $\begin{array}{c}28 \mathrm{psi} \\
195 \mathrm{kN} / \mathrm{m}^{2}\end{array}$ & $\begin{array}{c}308.6 \mathrm{lbs} \\
(140.00 \mathrm{~kg})\end{array}$ & $\begin{array}{c}0.378 \\
(9.6 \mathrm{~mm} / \mathrm{mm})\end{array}$ & $\begin{array}{c}0.277 \\
(4.539 \mathrm{~cm} / \mathrm{cm})\end{array}$ & $\begin{array}{c}0.86 \\
(21.84 \mathrm{~mm})\end{array}$ \\
\hline $\begin{array}{c}36 ” \\
(900 \mathrm{~mm})\end{array}$ & $\begin{array}{c}36.00 ” \\
(914 \mathrm{~mm})\end{array}$ & $\begin{array}{c}41.70 ” \\
(1059 \mathrm{~mm})\end{array}$ & $\begin{array}{c}0.067 ” \\
(1.7 \mathrm{~mm})\end{array}$ & $\begin{array}{c}22 \mathrm{psi} \\
150 \mathrm{kN} / \mathrm{m}^{2}\end{array}$ & $\begin{array}{c}396.8 \mathrm{lbs} \\
(180.00 \mathrm{~kg})\end{array}$ & $\begin{array}{c}0.401 \\
\left(10.19 \mathrm{~mm}^{2} / \mathrm{mm}\right)\end{array}$ & $\begin{array}{c}0.400 \\
(6.555 \mathrm{~cm} / \mathrm{cm})\end{array}$ & $\begin{array}{c}1.00 \\
(25.4 \mathrm{~mm})\end{array}$ \\
\hline $\begin{array}{c}42 ” \\
(1050 \mathrm{~mm})\end{array}$ & $\begin{array}{c}41.40 ” \\
(1054 \mathrm{~mm})\end{array}$ & $\begin{array}{c}47.70 ” \\
(1212 \mathrm{~mm})\end{array}$ & $\begin{array}{c}0.070 ” \\
(1.8 \mathrm{~mm})\end{array}$ & $\begin{array}{c}20 \mathrm{psi} \\
140 \mathrm{kN} / \mathrm{m}^{2}\end{array}$ & $\begin{array}{l}570.10 \mathrm{lbs} \\
(230.00 \mathrm{~kg})\end{array}$ & $\begin{array}{c}0.458 \\
2 \\
\left(11.64 \mathrm{~mm}^{2} / \mathrm{mm}\right)\end{array}$ & $\begin{array}{c}0.572 \\
4 \\
(9.373 \mathrm{~cm} / \mathrm{cm})\end{array}$ & $\begin{array}{c}1.21 \\
(30.73 \mathrm{~mm})\end{array}$ \\
\hline $\begin{array}{c}48 ” \\
(1200 \mathrm{~mm})\end{array}$ & $\begin{array}{c}47.60 ” \\
(1209 \mathrm{~mm})\end{array}$ & $\begin{array}{c}53.60 ” \\
(1361 \mathrm{~mm})\end{array}$ & $\begin{array}{c}0.070 ” \\
(1.8 \mathrm{~mm})\end{array}$ & $\begin{array}{c}18 \mathrm{psi} \\
125 \mathrm{kN} / \mathrm{m}^{2}\end{array}$ & $\begin{array}{c}625.00 \mathrm{lbs} \\
(283.50 \mathrm{~kg})\end{array}$ & $\begin{array}{c}0.495 \\
2 \\
\left(12.58 \mathrm{~mm}^{2} / \mathrm{mm}\right)\end{array}$ & $\begin{array}{c}0.570 \\
\left(9.341 \mathrm{~cm}^{4} / \mathrm{cm}\right)\end{array}$ & $\begin{array}{c}1.17 \\
(29.72 \mathrm{~mm})\end{array}$ \\
\hline $\begin{array}{c}60 ” \\
(1500 \mathrm{~mm})\end{array}$ & $\begin{array}{c}59.5 ” \\
(1512 \mathrm{~mm})\end{array}$ & $\begin{array}{c}66.30 ” \\
(1684 \mathrm{~mm})\end{array}$ & $\begin{array}{c}0.070 ” \\
(1.8 \mathrm{~mm})\end{array}$ & $\begin{array}{c}14 \mathrm{psi} \\
95 \mathrm{kN} / \mathrm{m}^{2}\end{array}$ & $\begin{array}{c}903.90 \mathrm{lbs} \\
(410.00 \mathrm{~kg})\end{array}$ & $\begin{array}{c}0.578 \\
{ }^{2} \\
\left(14.68 \mathrm{~mm}^{2} / \mathrm{mm}\right)\end{array}$ & $\begin{array}{c}0.860 \\
\left(14.09 \mathrm{~cm}^{4} / \mathrm{cm}\right)\end{array}$ & $\begin{array}{c}1.32 \\
(33.66 \mathrm{~mm})\end{array}$ \\
\hline
\end{tabular}


The thickness of the pipe is the difference between the inside and outside radius as shown below.

$$
t=\frac{O D-I D}{2}
$$

Where

$$
\begin{aligned}
& \mathrm{t}=\text { thickness of pipe (in) } \\
& \text { OD = outside diameter of pipe (in) } \\
& \text { ID = inside diameter of pipe (in) }
\end{aligned}
$$

The wall thickness for a 24-inch diameter pipe can be expressed as:

$$
t=\frac{27.80-24.08}{2}=1.86 \mathrm{in}
$$

Wall corrugations are difficult to model, so the geometry of the pipe is simplified to be a rectangular plain section without changing the structural stiffness of the pipe. The cross-section of the pipe is idealized as a rectangular section, and the moment of inertia can be calculated as follows:

$$
I=\frac{t^{3}}{12}=\frac{1.86^{3}}{12}=0.5362 \mathrm{in}^{4} / \mathrm{in}
$$

The material stiffness of the pipe needs to be changed in order to maintain the pipe stiffness because the geometric stiffness of the pipe was simplified into a rectangular plain section. The following formula shows this modification: 


$$
E_{d} I_{d}=E_{p} I_{p}
$$

Where

$$
\begin{aligned}
& E_{d}=\text { elastic modulus of corrugated section for dual-wall pipe } \\
& E_{p}=\text { elastic modulus of idealized rectangular section } \\
& I_{d}=\text { moment of inertia of corrugated section for dual-wall pipe } \\
& I_{p}=\text { moment of inertia of idealized rectangular section }
\end{aligned}
$$

$$
E_{p}=\frac{E_{d} I_{d}}{I_{p}}=\frac{110000 \times 0.137}{0.5362}=28105 p s i
$$

This procedure was done to calculate the thicknesses and material stiffness for each size of pipe. As indicated in the previous section, geometric and material properties were modified in the idealized pipe (Figure 3.4) in order to keep the actual pipe stiffness values. The section properties of the pipe diameters used in this study are shown in Table 3.2. Table 3.3 shows the modified geometric and material properties for the pipes used in this study. 


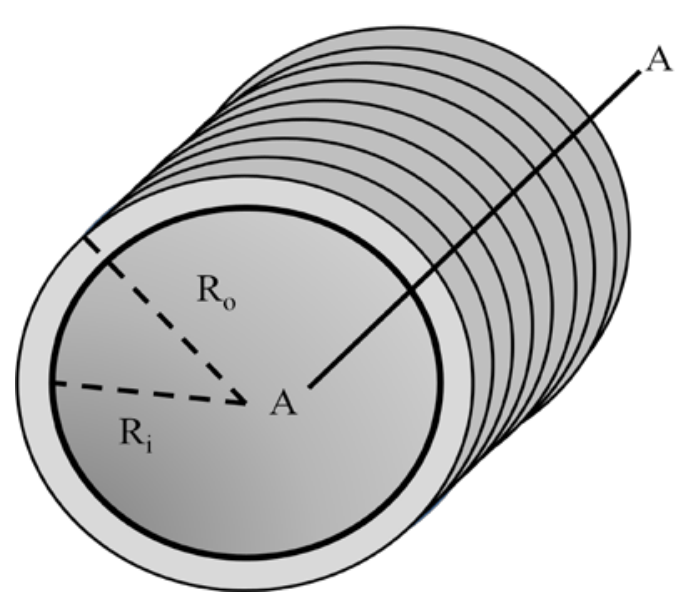

(a) Double-wall corrugated HDPE pipe

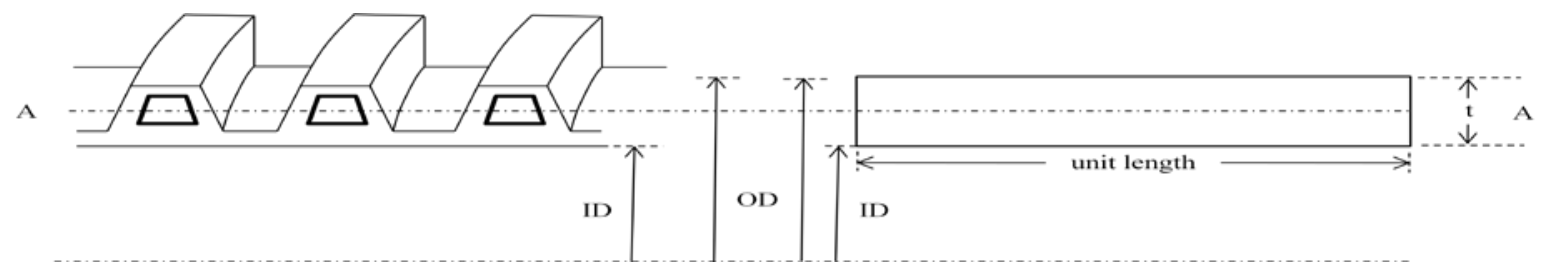

(b) Section A-A

(c) Idealized section

where

ID $=$ Inside Diameter

OD = Outside Diameter

$\mathrm{t}=$ thickness of the idealized rectangular section

Figure 3.4: Cross-section of a double-wall corrugated HDPE pipe (Gondle, 2008) 
Table 3.2: Sectional properties for HDPE used in research study (ADS Inc., 2006)

\begin{tabular}{|c|c|c|c|c|c|c|c|c|}
\hline $\begin{array}{l}\text { Nominal } \\
\text { Diameter }\end{array}$ & $\begin{array}{l}\text { Inside } \\
\text { Diameter }\end{array}$ & $\begin{array}{l}\text { Outside } \\
\text { Diameter } \\
\text { Average }\end{array}$ & $\begin{array}{l}\text { Inner Liner } \\
\text { Thickness, } \\
\text { Minimum }\end{array}$ & $\begin{array}{c}\text { Minimum Pipe } \\
\text { Stiffness at 5\% } \\
\text { Deflection }\end{array}$ & $\begin{array}{l}\text { Weight } \\
\text { Lbs/20ft } \\
\text { (kg./6m) }\end{array}$ & $\begin{array}{l}\text { Area } \\
\text { in }^{2} / \text { in }\end{array}$ & $\begin{array}{c}\text { "I" } \\
\text { in }^{4} \text { in }\end{array}$ & $\begin{array}{l}\text { "C" } \\
\text { in }\end{array}$ \\
\hline $\begin{array}{c}24 ” \\
(600 \mathrm{~mm})\end{array}$ & $\begin{array}{c}24.08 ” \\
(612 \mathrm{~mm})\end{array}$ & $\begin{array}{c}27.80 ” \\
(719 \mathrm{~mm})\end{array}$ & $\begin{array}{c}0.059 ” \\
(1.5 \mathrm{~mm})\end{array}$ & $\begin{array}{c}34 \mathrm{psi} \\
235 \mathrm{kN} / \mathrm{m}^{2}\end{array}$ & $\begin{array}{l}220.30 \mathrm{lbs} \\
(99.93 \mathrm{~kg})\end{array}$ & $\begin{array}{c}0.324 \\
2 \\
\left(8.23 \mathrm{~mm}^{2} / \mathrm{mm}\right)\end{array}$ & $\begin{array}{c}0.137 \\
\left(2.245 \mathrm{~cm}^{4} / \mathrm{cm}\right)\end{array}$ & $\begin{array}{c}0.74 \\
(18.8 \mathrm{~mm})\end{array}$ \\
\hline $\begin{array}{c}36 ” \\
(900 \mathrm{~mm})\end{array}$ & $\begin{array}{c}36.00 ” \\
(914 \mathrm{~mm})\end{array}$ & $\begin{array}{c}\text { 41.70” } \\
(1059 \mathrm{~mm})\end{array}$ & $\begin{array}{c}0.067 ” \\
(1.7 \mathrm{~mm})\end{array}$ & $\begin{array}{c}22 \mathrm{psi} \\
150 \mathrm{kN} / \mathrm{m}^{2}\end{array}$ & $\begin{array}{c}396.8 \text { lbs } \\
(180.00 \\
\text { kg) }\end{array}$ & $\begin{array}{c}0.401 \\
(10.19 \\
2 \\
\left.\mathrm{~mm}^{2} / \mathrm{mm}\right)\end{array}$ & $\begin{array}{c}0.400 \\
\left(6.555 \mathrm{~cm}^{4} / \mathrm{cm}\right)\end{array}$ & $\begin{array}{c}1.00 \\
(25.4 \mathrm{~mm})\end{array}$ \\
\hline $\begin{array}{c}48 ” \\
(1200 \mathrm{~mm})\end{array}$ & $\begin{array}{c}47.60 ” \\
(1209 \mathrm{~mm})\end{array}$ & $\begin{array}{c}53.60 ” \\
(1361 \mathrm{~mm})\end{array}$ & $\begin{array}{c}0.070 ” \\
(1.8 \mathrm{~mm})\end{array}$ & $\begin{array}{c}18 \mathrm{psi} \\
125 \mathrm{kN} / \mathrm{m}^{2}\end{array}$ & $\begin{array}{c}625.00 \mathrm{lbs} \\
(283.50 \\
\mathrm{kg})\end{array}$ & $\begin{array}{c}0.495 \\
(12.58 \\
2 \\
\left.\mathrm{~mm}^{2} / \mathrm{mm}\right)\end{array}$ & $\begin{array}{c}0.570 \\
\left(9.341 \mathrm{~cm}^{4} / \mathrm{cm}\right)\end{array}$ & $\begin{array}{c}1.17 \\
(29.72 \mathrm{~mm})\end{array}$ \\
\hline $\begin{array}{c}60 ” \\
(1500 \mathrm{~mm})\end{array}$ & $\begin{array}{c}\text { 59.5” } \\
(1512 \mathrm{~mm})\end{array}$ & $\begin{array}{c}66.30 ” \\
(1684 \mathrm{~mm})\end{array}$ & $\begin{array}{c}0.070 ” \\
(1.8 \mathrm{~mm})\end{array}$ & $\begin{array}{c}14 \mathrm{psi} \\
95 \mathrm{kN} / \mathrm{m}^{2}\end{array}$ & $\begin{array}{c}903.90 \mathrm{lbs} \\
(410.00 \\
\mathrm{kg})\end{array}$ & $\begin{array}{c}0.578 \\
(14.68 \\
2 / \mathrm{mm}) \\
\mathrm{mm}^{2} / \mathrm{mm}\end{array}$ & $\begin{array}{c}0.860 \\
\left(14.09 \mathrm{~cm}^{4} / \mathrm{cm}\right)\end{array}$ & $\begin{array}{c}1.32 \\
\text { (33.66 mm) }\end{array}$ \\
\hline
\end{tabular}


Table 3.3: Modified geometric and material properties for pipes used in this study

\begin{tabular}{|c|c|c|c|c|}
\hline \multirow{2}{*}{ Properties } & \multicolumn{4}{|c|}{ Double-wall Corrugated HDPE Pipe } \\
\hline & 24-inch & 36-inch & 48-inch & 60-inch \\
\hline Inside Diameter (ID) & $\begin{array}{l}24.08 \mathrm{in} \\
(612 \mathrm{~mm})\end{array}$ & $\begin{array}{l}36.00 \mathrm{in} \\
(914 \mathrm{~mm})\end{array}$ & $\begin{array}{c}47.60 \mathrm{in} \\
(1209 \mathrm{~mm})\end{array}$ & $\begin{array}{c}59.50 \mathrm{in} \\
(1511 \mathrm{~mm})\end{array}$ \\
\hline Outside Diameter (OD) & $\begin{array}{l}27.80 \mathrm{in} \\
(706 \mathrm{~mm})\end{array}$ & $\begin{array}{c}41.70 \mathrm{in} \\
(1059 \mathrm{~mm})\end{array}$ & $\begin{array}{l}53.60 \mathrm{in} \\
(1361 \mathrm{~mm})\end{array}$ & $\begin{array}{l}66.30 \mathrm{in} \\
(1684 \mathrm{~mm})\end{array}$ \\
\hline $\begin{array}{c}\text { Distance from inner wall to } \\
\text { neutral axis (C) }\end{array}$ & $\begin{array}{c}0.74 \mathrm{in} \\
(18.8 \mathrm{~mm})\end{array}$ & $\begin{array}{c}1.00 \mathrm{in} \\
(25.4 \mathrm{~mm})\end{array}$ & $\begin{array}{l}1.17 \mathrm{in} \\
(29.7 \mathrm{~mm})\end{array}$ & $\begin{array}{c}1.32 \mathrm{in} \\
(33.5 \mathrm{~mm})\end{array}$ \\
\hline Actual moment of Inertia, $I_{d}$ & $\begin{array}{c}0.137 \mathrm{in}^{4} / \mathrm{in} \\
\left(2.245 \mathrm{~cm}^{4} / \mathrm{cm}\right)\end{array}$ & $\begin{array}{c}0.400 \mathrm{in}^{4} / \mathrm{in} \\
\left(6.555 \mathrm{~cm}^{4} / \mathrm{cm}\right)\end{array}$ & $\begin{array}{c}0.570 \mathrm{in}^{4} / \mathrm{in} \\
\left(9.341 \mathrm{~cm}^{4} / \mathrm{cm}\right)\end{array}$ & $\begin{array}{c}0.860 \mathrm{in}^{4} / \mathrm{in} \\
\left(14.09 \mathrm{~cm}^{4} / \mathrm{cm}\right)\end{array}$ \\
\hline Actual Elastic Modulus, $E_{d}$ & $\begin{array}{c}110,000 \mathrm{psi} \\
\left(758,423 \mathrm{kN} / \mathrm{m}^{2}\right)\end{array}$ & $\begin{array}{c}110,000 \mathrm{psi} \\
\left(758,423 \mathrm{kN} / \mathrm{m}^{2}\right)\end{array}$ & $\begin{array}{c}110,000 \mathrm{psi} \\
\left(758,423 \mathrm{kN} / \mathrm{m}^{2}\right)\end{array}$ & $\begin{array}{c}110,000 \mathrm{psi} \\
\left(758,423 \mathrm{kN} / \mathrm{m}^{2}\right)\end{array}$ \\
\hline Thickness, $\mathrm{t}$ & $\begin{array}{c}1.86 \mathrm{in} \\
(47.2 \mathrm{~mm})\end{array}$ & $\begin{array}{c}2.85 \mathrm{in} \\
(72.4 \mathrm{~mm})\end{array}$ & $\begin{array}{c}3.0 \mathrm{in} \\
(76.2 \mathrm{~mm})\end{array}$ & $\begin{array}{c}3.4 \mathrm{in} \\
(86.4 \mathrm{~mm})\end{array}$ \\
\hline Moment of Inertia, $\mathrm{I}_{\mathrm{p}}$ & $\begin{array}{c}0.5362 \mathrm{in}^{4} / \mathrm{in} \\
\left(8.787 \mathrm{~cm}^{4} / \mathrm{cm}\right)\end{array}$ & $\begin{array}{c}1.929 \mathrm{in}^{4} / \mathrm{in} \\
\left(31.61 \mathrm{~cm}^{4} / \mathrm{cm}\right)\end{array}$ & $\begin{array}{c}2.25 \mathrm{in}^{4} / \mathrm{in} \\
\left(36.87 \mathrm{~cm}^{4} / \mathrm{cm}\right)\end{array}$ & $\begin{array}{c}3.28 \mathrm{in}^{4} / \mathrm{in} \\
\left(53.75 \mathrm{~cm}^{4} / \mathrm{cm}\right)\end{array}$ \\
\hline Elastic Modulus, $\mathrm{E}_{\mathrm{p}}$ & $\begin{array}{c}28105 \mathrm{psi} \\
\left(193777 \mathrm{kN} / \mathrm{m}^{2}\right)\end{array}$ & $\begin{array}{c}22808 \mathrm{psi} \\
\left(157256 \mathrm{kN} / \mathrm{m}^{2}\right)\end{array}$ & $\begin{array}{c}27867 \mathrm{psi} \\
\left(192136 \mathrm{kN} / \mathrm{m}^{2}\right)\end{array}$ & $\begin{array}{c}28882 \mathrm{psi} \\
\left(199134 \mathrm{kN} / \mathrm{m}^{2}\right)\end{array}$ \\
\hline
\end{tabular}

\subsection{Properties of Solid-wall PVC Pipes}

In this study, only 18-inch diameter and 24-inch diameter solid-wall PVC pipes were considered. The sectional properties of PVC pipes used in this research study are shown in Table 3.4. Table 3.5 shows the section properties used in this study for the different sized solidwall PVC pipes. 
Table 3.4: Specification Data for PVC Pipes (Diamond Plastics, 2005)

\begin{tabular}{|c|c|c|c|}
\hline Nominal Pipe Size & Outside Diameter & $\begin{array}{c}\text { Wall Thickness } \\
\text { SDR26/PS115 }\end{array}$ & $\begin{array}{c}\text { Wall Thickness } \\
\text { SDR35/PS46 }\end{array}$ \\
\hline $\begin{array}{c}18 ” \\
(457.2 \mathrm{~mm})\end{array}$ & $\begin{array}{c}18.701 ” \\
(475 \mathrm{~mm})\end{array}$ & $\begin{array}{c}0.671 ” \\
(17.0 \mathrm{~mm})\end{array}$ & $\begin{array}{c}0.499 ” \\
(12.7 \mathrm{~mm})\end{array}$ \\
\hline $21 ”$ & $22.047 ”$ & $0.791 ”$ & $0.588 ”$ \\
$(533.4 \mathrm{~mm})$ & $(20.1 \mathrm{~mm})$ & $(14.9 \mathrm{~mm})$ \\
\hline $24 ”$ & $24.803 ”$ & $0.889 ”$ & $0.661 ”$ \\
$(609.6 \mathrm{~mm})$ & $(630 \mathrm{~mm})$ & $(22.6 \mathrm{~mm})$ & $(16.8 \mathrm{~mm})$ \\
\hline $27 ”$ & $27.953 ”$ & $1.002 ”$ & $0.745 ”$ \\
$(685.8 \mathrm{~mm})$ & $(710.0 \mathrm{~mm})$ & $(25.4 \mathrm{~mm})$ & $(18.9 \mathrm{~mm})$ \\
\hline $30 ”$ & $32.000 ”$ & $1.148 ”$ & $0.853 ”$ \\
$(762 \mathrm{~mm})$ & $(812.8 \mathrm{~mm})$ & $(29.2 \mathrm{~mm})$ & $(21.7 \mathrm{~mm})$ \\
\hline
\end{tabular}

Table 3.5: Sectional properties of PVC pipe used in research study (Diamond Plastics, 2005)

\begin{tabular}{|c|c|c|c|}
\hline Nominal Pipe Size & Outside Diameter & $\begin{array}{c}\text { Wall Thickness } \\
\text { SDR26/PS115 }\end{array}$ & $\begin{array}{c}\text { Wall Thickness } \\
\text { SDR35/PS46 }\end{array}$ \\
\hline $18 ”$ & $\begin{array}{c}18.701 ” \\
(475 \mathrm{~mm})\end{array}$ & $\begin{array}{c}0.671 ” \\
(17.0 \mathrm{~mm})\end{array}$ & $\begin{array}{c}0.499 ” \\
(12.7 \mathrm{~mm})\end{array}$ \\
\hline $247.2 \mathrm{~mm})$ & $24.803 ”$ & $0.889 ”$ & $0.661 ”$ \\
$(609.6 \mathrm{~mm})$ & $(630 \mathrm{~mm})$ & $(22.6 \mathrm{~mm})$ & $(16.8 \mathrm{~mm})$ \\
\hline
\end{tabular}

\subsection{Introduction to Time-Dependent Behavior of Soil}

Soil consolidation occurs when a load is applied to a saturated soil medium (Das, 2006). This consolidation may cause additional stresses acting on the pipe. The interaction between the soil and pipe structure is a key factor that influences the load acting on the pipe (Helwany, 2007). Consolidation settlement can be analyzed by using mathematical methods derived in the literature (Terzaghi, 1925; Das, 2006). Another approach to analyzing the process of consolidation is by the use of numerical methods. Due to the advancement of computers, finiteelement programs are frequently used in the analysis of consolidation problems (Lewis, 1998). Details of the Finite element methods (FEM) will be discussed in Chapter 5. 


\subsubsection{Soil-Pipe System}

The relative displacements between the soil and pipe play an important role in the soilpipe interaction. Both soil and pipe have different stress-strain characteristics. In the initial stages of soil consolidation, it is difficult to determine the resultant stresses at the soil-pipe interface due to higher stresses occurring in the pipe and lesser stresses occurring in the surrounding soil (Helwany, 2007).

Most consolidation problems that have been analyzed do not consider the interaction between the structure and soil (Lewis, 1998). The load transfer mechanism between the soil and pipe is complex due to the interfaces between the soil and structure. Also, the mathematics involved in such an analysis are quite complex (Lewis, 1998). To study the interaction between the soil and structure, the finite element method can be used to incorporate interface elements between the soil and pipe (Lewis, 1998).

\subsubsection{Elastic Settlement}

Compression of soil is caused by the deformation of soil particles, relocation of these particles, and the expulsion of water or air present in the voided areas (Das, 2006). The immediate settlement of the soil is also referred to as elastic settlement. It is caused by the elastic deformation of soil without change in moisture content. The magnitude of this settlement depends on the flexibility of the pipe and the type of soil material (Lewis, 1998). If the ground is considered to be perfectly flexible, i.e. saturated clay, the pressure will be uniform and the foundation will have a sagging profile. For a perfectly rigid structure, the foundation will undergo a uniform settlement and the contact pressure will be redistributed. In a clay soil, elastic settlement occurs immediately (Das, 2006).

\subsubsection{Background of Soil Consolidation}

The dissipation of the excess pore pressure from the soil medium under a load is called consolidation (Das, 2006). Consolidation is a time-dependent process, and depends upon the length of the drainage path, permeability of the soil, and compressibility of the soil (Helwany, 2007). Figure 3.5 graphically shows the stages of consolidation of a soil mass. Primary 
consolidation is caused by volume changes that occur in saturated cohesive soils due to the dissipation of pressure in the water that exists in the voids. Secondary consolidation settlement is caused by the plastic adjustment of saturated cohesive soils (Das, 2006). The soil consolidation process has been described in detail in the literature (Das, 2006; Terzaghi, 1925).

\section{Primary Consolidation}

Primary consolidation is caused by the dissipation of pore pressure throughout a saturated cohesive soil which leads to a change in volume. In a saturated soil layer, an increase in stress results in a sudden increase in the pore water pressure (Das, 2006). This causes settlement due to reduction in volume of the soil media. It takes a long period of time for the pore water dissipation to be completed due to the low hydraulic conductivity of clay. Consolidation will continue over a long period of time (Das, 2006).

\section{$\underline{\text { Secondary Consolidation }}$}

Secondary consolidation can be defined as the continuous deformation of a soil medium after the excess pore pressure has been dissipated (Das, 2006). This is caused by the timedependent deformation characteristic of soil particles, which is not related to excess pore

pressure dissipation (Helwany, 2007). The settlements that occur due to this secondary consolidation are small compared to the primary consolidation (Terzaghi, 1925).

\subsubsection{Influence of Pore Pressure on Buried Pipes}

Pore pressure increases when a saturated soil is loaded. This excess pore pressure dissipates from the boundaries of the soil layer over a time period (Das, 2006; Helwany, 2007). The excess pore pressures are the driving forces for water flow according to Darcy's law (Lovisa et al., 2010). This excess pore pressure generates a hydraulic gradient which causes flow.

When pore pressure develops in highly permeable materials, such as gravel, due to rapid loading conditions, the excess pore pressure dissipates rapidly. Conversely, when silts and clays 
are loaded, the excess pore pressure slowly dissipates because of the low permeabilities of these materials (Fetter, 2001). Consolidation continues to occur until all of the pore water pressure dissipates from the soil (Helwany, 2007). Depending upon the type of application, pipe backfill materials can be granular stone or cohesive soils. As such, the pore pressure dissipation around a buried pipe may influence the pipe deflections.

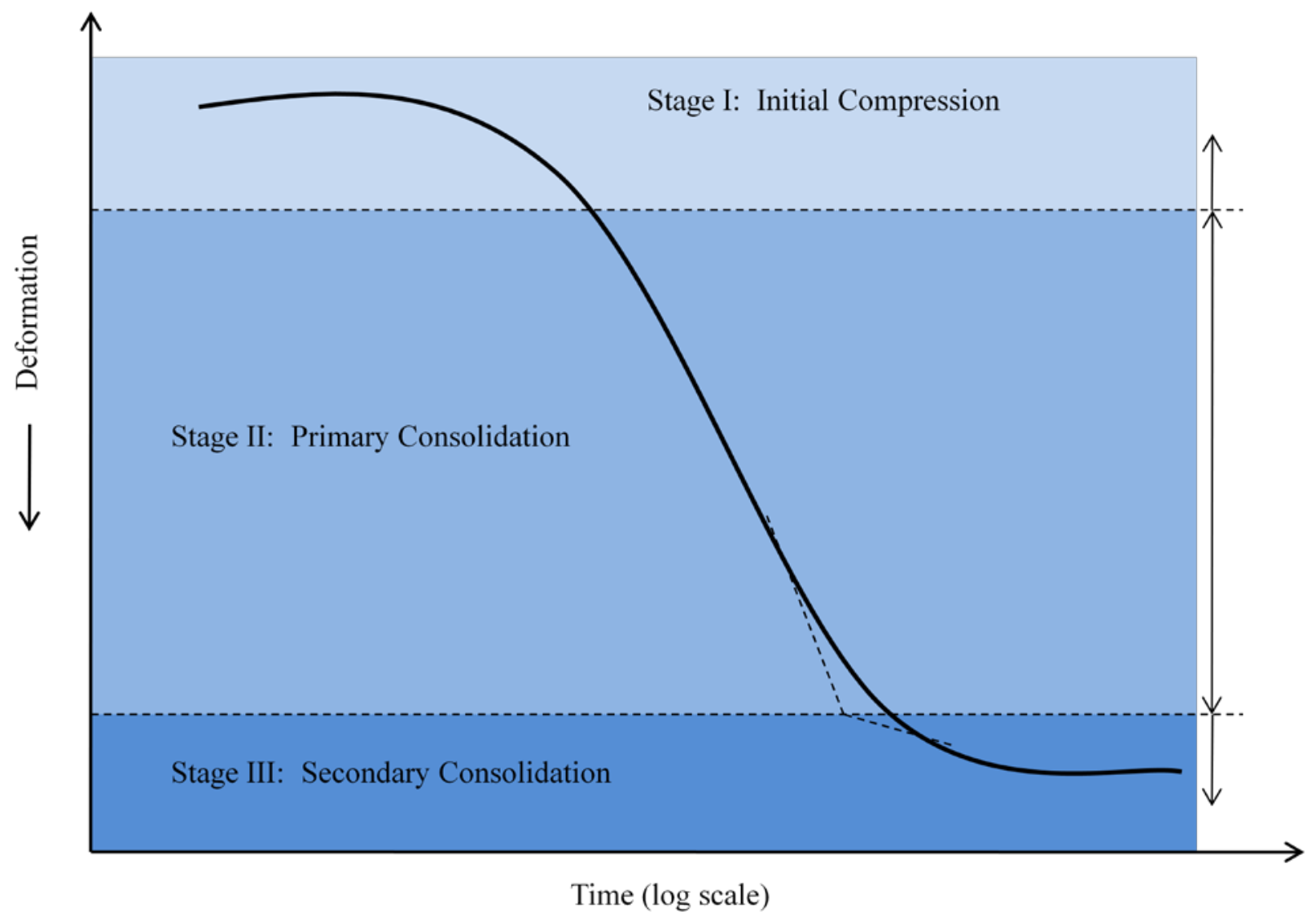

Figure 3.5: Time vs. deformation plot during consolidation

(Das, 2006) 


\section{CHAPTER 4: INFLUENCE OF SOIL CONSOLDATION ON THE PERFORMANCE OF PIPES}

\subsection{Introduction}

Finite element method (FEM) has been used throughout recent years to analyze complex problems (Simulia, 2010; Cook et al, 2003; Watkins and Anderson, 1999; Hibbitt et al, 1970). In the present research work, the finite element software ABAQUS was used to analyze the timedependent behavior of buried high-density polyethylene (HDPE) pipes and polyvinylchloride (PVC) pipes. In this chapter, mathematical details of the finite element formulation for creep

analysis of the pipe and soil consolidation are presented. FEM has been used in the past to simulate various construction methods (i.e. trench and embankment conditions), pipe backfill materials, different pipe diameters, and materials (Sargand et al., 1993).

In this study, two-dimensional transient analyses were performed to investigate the performance of HDPE and PVC pipes over a time period of 50 years. Creep of the pipe and consolidation of the surrounding soil were the two time-dependent processes considered in the analyses. Backfill heights ranging from 10 feet to 50 feet were considered, as well as trenchwidth ratios ranging from 1.5 to 2.5. The trench-width ratio is defined as the ratio of the trenchwidth to the nominal pipe diameter.

\subsection{Previous Studies}

The finite element method has been used to model pipe-soil interaction in the past (Gondle and Siriwardane, 2008; Gondle, 2006; Mada, 2005; Watkins and Anderson, 1999; Moore, 1994; Moser, 1990; Sandhu and Wilson, 1969). To simulate pipe-soil interaction, special elements for the interface (interface elements) were also used (Lewis, 1998). Finite element formulations can also be used with realistic constitutive models that fully represent saturated consolidating soil. Finite element formulation for liner elastic soil consolidation was reported as 
early as late 1960s (Sandhu and Wilson, 1969; Lewis, 1998). Several recent analyses of pipe soil systems by using the finite element method can be found in the literature.

\subsection{Finite Element Analysis}

In this section, a brief description of the mathematical formulation of the finite element method is presented. More details of the finite element formulations can be found elsewhere (Desai \& Abel, 1972; Cook et at, 2003; Zienkewicz and Taylor, 1987; Gondle, 2008; Simulia, 2010). The governing element equation can be expressed as the following:

$$
[K]\{r\}=\{R\}
$$

Where

$$
\begin{aligned}
& {[\mathrm{K}]=\text { global stiffness matrix }} \\
& \{\mathrm{r}\}=\text { global displacement vector } \\
& \{\mathrm{R}\}=\text { global load vector }
\end{aligned}
$$

The stiffness matrix is a function of the structural geometry, element dimensions, element properties, and element shape functions (Desai \& Abel, 1972; Cook et at, 2003; Zienkewicz and Taylor, 1987). In this research study, two-noded beam elements were used to model pipe bending behavior. Isoparametric quadrilateral elements are used to model soil behavior in the pipe-soil system. A typical beam element is shown in Figure 5.1. Each node in the beam element has two degrees of freedom, as shown in this figure.

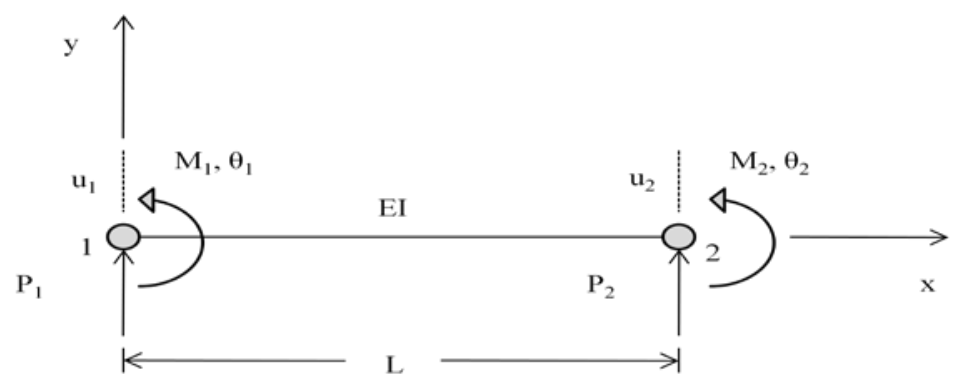

Figure 4.1: Two-noded beam element

(Gondle, 2008) 
For a two-dimensional beam element, the stiffness matrix $[\mathrm{k}]$ and the vector of nodal unknowns can be expressed as:

$$
\begin{gathered}
{[k]_{4 X 4}=\left[\begin{array}{cccc}
\frac{12 E I}{L^{3}} & \frac{6 E I}{L^{2}} & -\frac{12 E I}{L^{3}} & \frac{6 E I}{L^{2}} \\
\frac{6 E I}{L^{2}} & \frac{4 E I}{L} & -\frac{6 E I}{L^{2}} & \frac{2 E I}{L} \\
-\frac{12 E I}{L^{3}} & -\frac{6 E I}{L^{2}} & \frac{12 E I}{L^{3}} & -\frac{6 E I}{L^{2}} \\
\frac{6 E I}{L^{2}} & \frac{2 E I}{L} & \frac{6 E I}{L^{2}} & \frac{4 E I}{L}
\end{array}\right]_{4 \times 4}} \\
\{q\}=\left\{\begin{array}{l}
u_{1} \\
\theta_{1} \\
u_{2} \\
\theta_{2}
\end{array}\right\}_{4 \times 1}
\end{gathered}
$$

where $E$ is the elastic modulus and $I$ is the moment of inertia of the beam section. Governing equations for a beam element can be expressed as:

$$
[K]\{q\}=\{Q\}
$$

where

$$
\begin{aligned}
& {[\mathrm{K}]=\text { beam element stiffness matrix }} \\
& \{\mathrm{q}\}=\text { displacement vector }=\left\{\begin{array}{llll}
u_{1} & \theta_{1} & u_{2} & \theta_{2}
\end{array}\right\}^{T} \\
& \{\mathrm{Q}\}=\text { load vector }=\left\{\begin{array}{llll}
P_{1} & M_{1} & P_{2} & M_{2}
\end{array}\right\}^{T}
\end{aligned}
$$


A typical iso-parametric element used in the modeling of soil mass is shown in Figure 4.2. The displacements at any point in the element can be expressed as:

$$
\begin{gathered}
\mathrm{u}=\sum_{i=1}^{4} N_{i} u_{i} \\
\mathrm{v}=\sum_{i=1}^{4} N_{i} v_{i}
\end{gathered}
$$

where

$\mathrm{u}_{\mathrm{i}}$ : represents the nodal displacements in the $\mathrm{x}$-direction,

$\mathrm{v}_{\mathrm{i}}$ : represents the displacements in the $\mathrm{y}$-direction, and

$\mathrm{N}_{\mathrm{i}}$ : represents the interpolation functions in the local coordinate system.

The nodal displacements can also be expressed in matrix form as:

$$
\{U\}=[N]\{q\}
$$

or

$$
\left\{\begin{array}{l}
u \\
v
\end{array}\right\}=\left[\begin{array}{cccccccc}
N_{1} & 0 & N_{2} & 0 & N_{3} & 0 & N_{4} & 0 \\
0 & N_{1} & 0 & N_{2} & 0 & N_{3} & 0 & N_{4}
\end{array}\right]\left\{\begin{array}{l}
u_{1} \\
v_{1} \\
u_{2} \\
v_{2} \\
u_{3} \\
v_{3} \\
u_{4} \\
v_{4}
\end{array}\right\}
$$




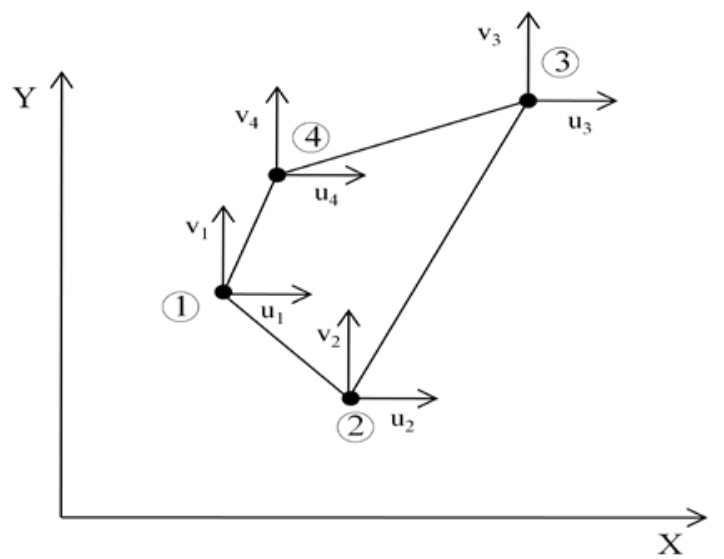

(a) Global coordinate system

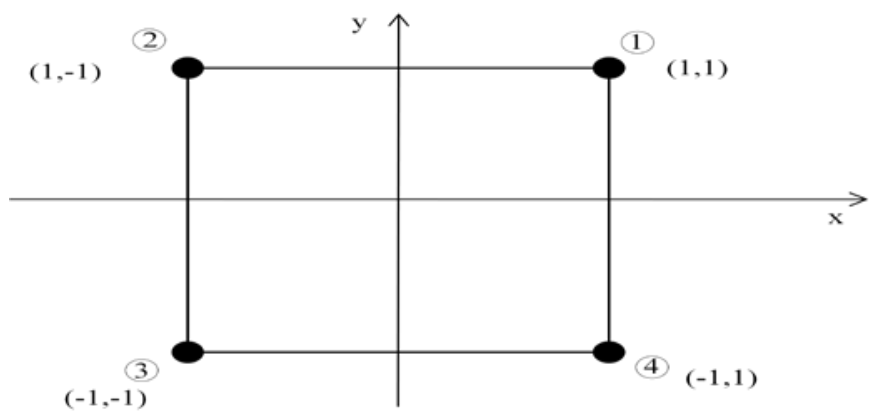

(b) Local coordinate system

Figure 4.2: Coordinate systems

(Gondle, 2008; Desai and Abel, 1972) 
$\mathrm{N}_{\mathrm{i}}(\mathrm{i}=1$ to 4$)$ are interpolation functions, which can be expressed as

$$
N_{i}=\frac{1}{4}\left(1+r r_{i}\right)\left(1+s s_{i}\right)
$$

The variables $r$ and $s$ represent the local coordinate system. The constitutive relationship can be expressed as:

$$
\{\sigma\}=[C]\{\varepsilon\}
$$

where $\{\sigma\}$ represents the stress vector:

$$
\{\sigma\}=\left\{\begin{array}{lll}
\sigma_{x x} & \sigma_{y y} & \tau_{x y}
\end{array}\right\}^{T}
$$

$\{\varepsilon\}$ represents the strain:

$$
\{\varepsilon\}=\left\{\begin{array}{lll}
\varepsilon_{x x} & \varepsilon_{y y} & \varepsilon_{x y}
\end{array}\right\}^{T}=[B]\{q\}
$$

$[\mathrm{C}]$ is the constitutive matrix:

$$
[C]=\left[\begin{array}{lll}
C_{11} & C_{12} & C_{13} \\
C_{21} & C_{22} & C_{23} \\
C_{31} & C_{32} & C_{33}
\end{array}\right]
$$


The strain-displacement relationships can be used to derive the strain vector $\{\varepsilon\}$ :

$$
\begin{gathered}
\varepsilon_{x x}=\frac{\partial u}{\partial x} \\
\varepsilon_{y y}=\frac{\partial v}{\partial y} \\
\gamma_{x y}=\frac{\partial u}{\partial y}+\frac{\partial v}{\partial x}
\end{gathered}
$$

Where

$$
\begin{aligned}
& \varepsilon_{\mathrm{xx}}=\text { normal strain along } \mathrm{x} \text {-axis } \\
& \varepsilon_{\mathrm{yy}}=\text { normal strain along } \mathrm{y} \text {-axis } \\
& \gamma_{\mathrm{xy}}=\text { shear strain }
\end{aligned}
$$

The strain vector can be expressed in terms of nodal displacement vector as:

$$
\{\varepsilon\}=[B]\{q\}
$$

Here the matrix $[\mathrm{B}]$ is the strain-displacement transformation matrix. This matrix consists of global derivatives of interpolation functions, $\mathrm{N}_{\mathrm{i}}$, which are expressed in local coordinates. The element equations can be expressed as:

$$
[K]\{q\}=\{Q\}
$$

Where $[k]=\iiint[B]^{T}[C][B] d v$ 
and $\{Q\}=\iiint[N]^{T}\{\bar{Y}\} d V+\iint[N]^{T}\{\bar{T}\} d S+\left\{P_{i}\right\}$

Here $\bar{Y}$ is the body force vector, $\bar{T}$ is the surface traction vector, and $\mathrm{P}_{\mathrm{i}}$ is the point load vector.

\subsection{Creep Formulation in the Finite Element Analysis}

The time-dependent elastic modulus $E(t)$ is needed in order to model the creep behavior of buried pipes (Gondle and Siriwardane, 2008; Gondle, 2006; Callister, 1991). The timehardening law and strain-hardening law are the two versions of hardening used with the powerlaw model. The time-hardening law is used in this study. The following equation represents the time-hardening creep law in the finite element model (Gondle, 2006; Simulia, 2010):

$$
\varepsilon^{. c r}=A \sigma^{m} t^{n}
$$

Where

$$
\begin{aligned}
& \dot{\varepsilon}^{c r}=\text { creep strain rate } \\
& \mathrm{A}=\text { determines the level of overall creep deformation } \\
& \mathrm{n}=\text { describes the dependence of the creep rate and stress level } \\
& \mathrm{m}=\text { changes the curvature of the curve }
\end{aligned}
$$

The creep constants used for the HDPE pipe were obtained through a back calculation procedure as described elsewhere (Hashash, 1998; Gondle, 2006; Gondle and Siriwardane, 2008). The following power-law model was used in this study. 


$$
\varepsilon(t)=\frac{\sigma}{E(t)}=\frac{\sigma}{51,586.38 t^{-0.0859}}=\left(\frac{1}{51,586.38}\right) \sigma^{(1)} t^{0.0859}
$$

The creep strain rate can be obtained as shown below:

$$
\begin{aligned}
\varepsilon(t) & =\frac{d \varepsilon(t)}{d t}=\left(\frac{1}{51586.38} \times 0.0859\right) \sigma^{(1)} t^{0.0859-1} \\
& =\left(1.665 \times 10^{-6}\right) \sigma^{(1)} t^{-0.9141} \quad \text { (time units in days) }
\end{aligned}
$$

The creep model used for PVC pipes is described in the literature (Janson, 1985). The creep constants used for the PVC pipe were obtained through a back calculation procedure similar to that presented earlier. Janson's power-law model (1985) can be expressed as:

$$
\varepsilon(t)=\frac{\sigma}{E(t)}=\frac{\sigma}{329067.99 t^{-0.0567}}=\left(\frac{1}{329067.99}\right) \sigma^{(1)} t^{0.0567}
$$

The creep strain rate can be obtained as shown below:

$$
\begin{aligned}
\varepsilon(t) & =\frac{d \varepsilon(t)}{d t}=\left(\frac{1}{329067.99} \times 0.0567\right) \sigma^{(1)} t^{0.0567-1} \\
& =\left(1.723 \times 10^{-7}\right) \sigma^{(1)} t^{-0.9433} \quad \text { (time units in days) }
\end{aligned}
$$


A summary of creep constants used for HDPE and PVC pipes is presented in Table 4.2.

Table 4.1: Creep constants used for PVC and HDPE pipe materials

\begin{tabular}{|c|c|c|c|}
\hline Pipe Material & A & n & m \\
\hline HDPE & $1.665 \times 10^{-6}$ & 1 & -0.9141 \\
\hline PVC & $1.723 \times 10^{-7}$ & 1 & -0.9433 \\
\hline
\end{tabular}

*note that these are in units of days

\subsection{Finite Element formulation of Soil Consolidation}

The mathematical details of the finite element formulation of the soil consolidation problem can be found elsewhere (Booker, 1977; Bentler, 1998; Gudehus, 1977, Biot, 1940). A brief summary is given below. Equations of equilibrium provide governing equations for coupled flow and deformation (i.e., consolidation) process. The equilibrium equation can be expressed as:

$$
\sigma_{i j, j}=0
$$

where

$$
\sigma_{\mathrm{ij}}: \text { total stress tensor at a point in the soil }
$$

The pore pressure and the effective stresses are related through the principal of effective stress as shown below.

$$
\sigma_{i j, j}=\sigma_{i j, j}^{\prime}+p_{w, j}=0
$$


where

$$
\begin{aligned}
& \sigma_{i j, j}=\text { total stress } \\
& \sigma_{i j, j}^{\prime}=\text { effective stress } \\
& p_{w, j}=\text { pore pressure }
\end{aligned}
$$

Fluid flow in the porous medium is governed by the Darcy’s Law, as presented below.

$$
v_{i}=k_{i j} h_{, j}
$$

where

$$
\begin{aligned}
& k_{i j}=\text { permeability matrix } \\
& h_{, j}=\text { total head gradient in the } \mathrm{xj} \text { direction }
\end{aligned}
$$

The complete mathematical derivation of governing equations can be found elsewhere in the literature (Lewis and Schrefler, 1998). The finite element equations for a linear elastic consolidation solution can be written as (Lewis and Schrefler, 1998):

$$
\left[\begin{array}{cc}
K & R \\
0 & H_{C}
\end{array}\right]\left\{\begin{array}{c}
\bar{u} \\
\bar{p}_{w}
\end{array}\right\}+\left[\begin{array}{cc}
0 & 0 \\
R^{T} & M
\end{array}\right] \frac{d}{d t}\left\{\begin{array}{c}
\bar{u} \\
\bar{p}_{w}
\end{array}\right\}=\left\{\begin{array}{l}
f^{u} \\
f
\end{array}\right\}
$$

where

$\mathrm{u}$ and $\mathrm{p}^{\mathrm{w}}$ are the vectors of nodal values of unknown displacements and pore pressure 
$[\mathrm{K}]$ is the stiffness matrix:

$$
[K]=\int_{V}[B]^{T}[C][B] d V
$$

$[R]$ is the coupling matrix:

$$
[R]=\int_{V}[B]^{T} \alpha m d V
$$

[B] is strain-displacement matrix

$[\mathrm{C}]$ is the constitutive stress-strain matrix

$\left[\mathrm{H}_{\mathrm{c}}\right]$ is the permeability (hydraulic conductivity) matrix and is given by

$$
\left[H_{C}\right]=\int_{V}\left[\nabla N_{p}\right]^{T} \frac{k}{\mu_{W}} \nabla N_{p} d V
$$

$[\mathrm{M}]$ is the compressibility matrix which is given by

$$
[M]=\int_{V} N_{p} T\left(\frac{\alpha-n}{K_{S}}+\frac{n}{k_{W}}\right) N_{p} d V
$$

$\mathrm{f}^{\mathrm{u}}$ and $\mathrm{f}^{\mathrm{p}}$ are load vectors which can be written as

$$
f^{u}=\int_{V} N_{u}^{T}\left(\rho_{S}(n-1)+\rho_{w} n\right) g d V+\int_{S} N_{u}^{T} \bar{t} d S
$$




$$
f^{u}=\int_{V}\left(\nabla N_{p}\right)^{T} \frac{k}{\mu_{w}} \rho^{w} g d V-\int_{S} N_{U}^{T} \frac{q}{\rho_{w}} d S
$$

and

$\mathrm{N}_{\mathrm{u}}$ and $\mathrm{N}_{\mathrm{p}}$ are shape functions. 


\section{CHAPTER 5: METHOD OF ANALYSIS}

\subsection{Introduction}

In order to investigate the combined influence of the time-dependent behavior of buried pipes and soil consolidation, the finite element method was used as the method of analysis in this research study. The method of analysis used in the finite element modeling of creep and consolidation is presented in this chapter. Different numerical procedures were used to understand soil consolidation and creep of buried pipes and these procedures are also presented in this chapter.

\subsection{Creep and Consolidation Analysis}

The creep of the pipe and soil consolidation are the main time-dependent components considered in this study. The method of analysis is described below.

\subsubsection{Parts and Properties}

Four parts were created in the analyses: pipe backfill soil, insitu soil, trench backfill soil, and the pipe, as shown in Figure 5.1. The soil (backfill, trench, and insitu) and pipe parts were assembled to construct the pipe-soil system. Table 5.1 shows the soil properties and Table 5.2 shows the pipe properties used in this study. In this analysis, the permeability of soil remains constant over the 50-year consolidation time period (i.e., duration of the analysis). However, it is possible to incorporate time-dependent permeability in the analysis as the void ratio is reduced during the consolidation process (Booker \& Small, 1977). Figures 5.2 and 5.3 show an example of different material types in a typical cross-section. Figure 5.2 shows an HDPE pipe buried in a clay backfill and Figure 5.3 shows a PVC pipe with a granular backfill material.

\subsubsection{Steps in the Analysis}

First, the geostatic step was activated to ensure that equilibrium is achieved throughout the soil (Helwany, 2007). For the trench backfill loading analyses (see Chapter 2, section 2.7.1), the trench was excavated, and then replaced in order to simulate pore pressure development 
around the pipe. Table 5.3 shows the time-steps used in the analysis of the trench backfill loading.

During the embankment loading condition, the soil was present from the beginning. Gravity loading condition was used to simulate pore pressure development around the pipe. Table 5.4 shows time steps used for the embankment loading procedure.

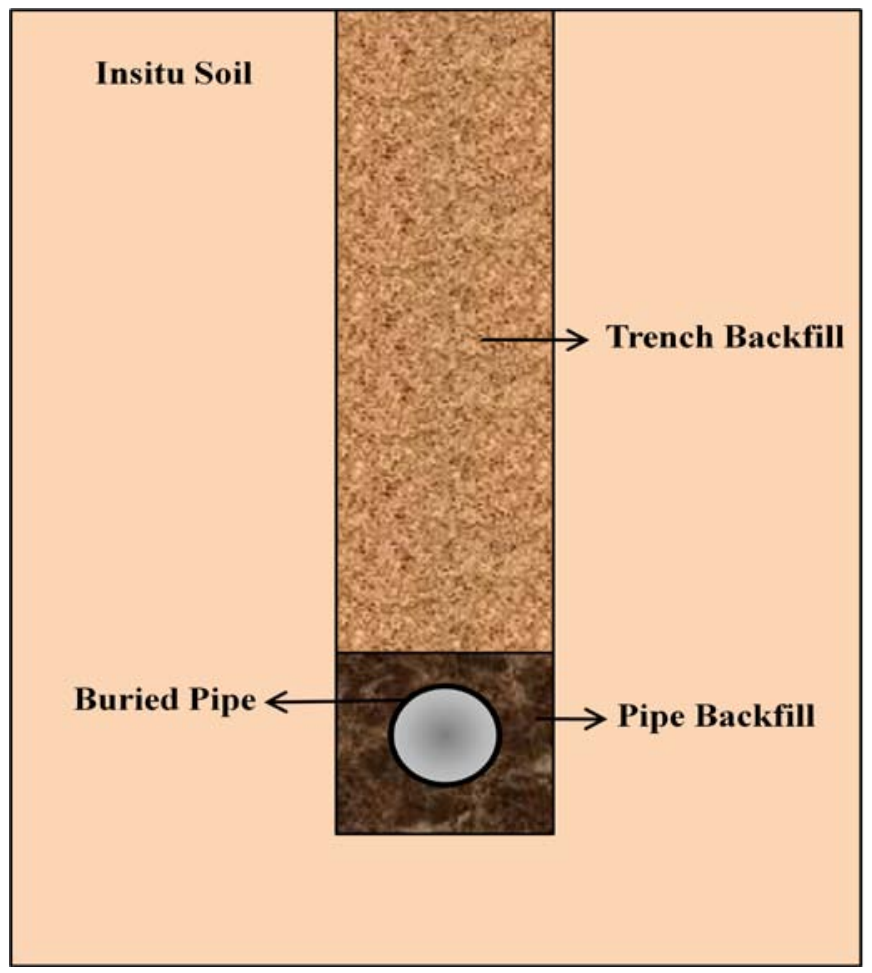

Figure 5.1: Cross-section of a pipe-soil model 
Table 5.1: Soil properties used in the present study

\begin{tabular}{|c|c|c|c|c|c|c|}
\hline Soil Type & & $\begin{array}{c}\text { Elastic } \\
\text { Modulus, } \\
\text { psi } \\
\left(\mathbf{k N} / \mathbf{m}^{2}\right)\end{array}$ & $\begin{array}{l}\text { Poisson's } \\
\text { Ratio }\end{array}$ & $\begin{array}{l}\text { Void } \\
\text { Ratio }\end{array}$ & $\begin{array}{c}\begin{array}{c}\text { Dry } \\
\text { Density, }\end{array} \\
\text { pci } \\
\left(\mathbf{k g} / \mathbf{m}^{3}\right)\end{array}$ & $\begin{array}{c}\text { Permeability, } \\
\text { inch/day } \\
\text { (mm/day) }\end{array}$ \\
\hline Insitu Soil & & $\begin{array}{c}700 \\
(4826)\end{array}$ & 0.35 & 0.60 & $\begin{array}{l}0.0501 \\
(1387)\end{array}$ & $\begin{array}{l}0.03404 \\
(0.865)\end{array}$ \\
\hline $\begin{array}{l}\text { Trench } \\
\text { Backfill }\end{array}$ & & $\begin{array}{c}700 \\
(4826)\end{array}$ & 0.35 & 0.60 & $\begin{array}{l}0.0501 \\
(1387)\end{array}$ & $\begin{array}{l}0.03404 \\
(0.865)\end{array}$ \\
\hline \multirow[t]{2}{*}{ Pipe Backfill } & Granular & $\begin{array}{c}3000 \\
(20684)\end{array}$ & 0.30 & 0.57 & $\begin{array}{l}0.0845 \\
(2339)\end{array}$ & $\begin{array}{c}340.412 \\
(8646)\end{array}$ \\
\hline & Clay & $\begin{array}{c}700 \\
(4826)\end{array}$ & 0.35 & 0.60 & $\begin{array}{l}0.0501 \\
(1387)\end{array}$ & $\begin{array}{l}0.03404 \\
(0.865)\end{array}$ \\
\hline
\end{tabular}

Table 5.2: Pipe properties used in the present study

\begin{tabular}{|c|c|c|c|c|c|c|}
\hline & & & & \multicolumn{3}{|c|}{ Creep Parameters } \\
\hline $\begin{array}{c}\text { Pipe } \\
\text { Material }\end{array}$ & $\begin{array}{c}\text { Density, } \\
\text { pci } \\
\left(\mathbf{k g} / \mathrm{m}^{3}\right)\end{array}$ & $\begin{array}{c}\text { Elastic Modulus, } \\
\text { psi } \\
\left(\mathbf{k N} / \mathbf{m}^{2}\right)\end{array}$ & $\begin{array}{l}\text { Poisson's } \\
\text { Ratio }\end{array}$ & A & $\mathbf{n}$ & m \\
\hline PVC & $\begin{array}{l}0.0499 \\
(1381)\end{array}$ & $\begin{array}{c}400000 \\
(2757903)\end{array}$ & 0.41 & $1.723 \times 10^{-7}$ & 1 & -0.9433 \\
\hline HDPE & $\begin{array}{l}0.0347 \\
(960)\end{array}$ & $\begin{array}{l}\text { Dependent on } \\
\text { pipe diameter }\end{array}$ & 0.46 & $1.665 \times 10^{-6}$ & 1 & -0.9141 \\
\hline
\end{tabular}




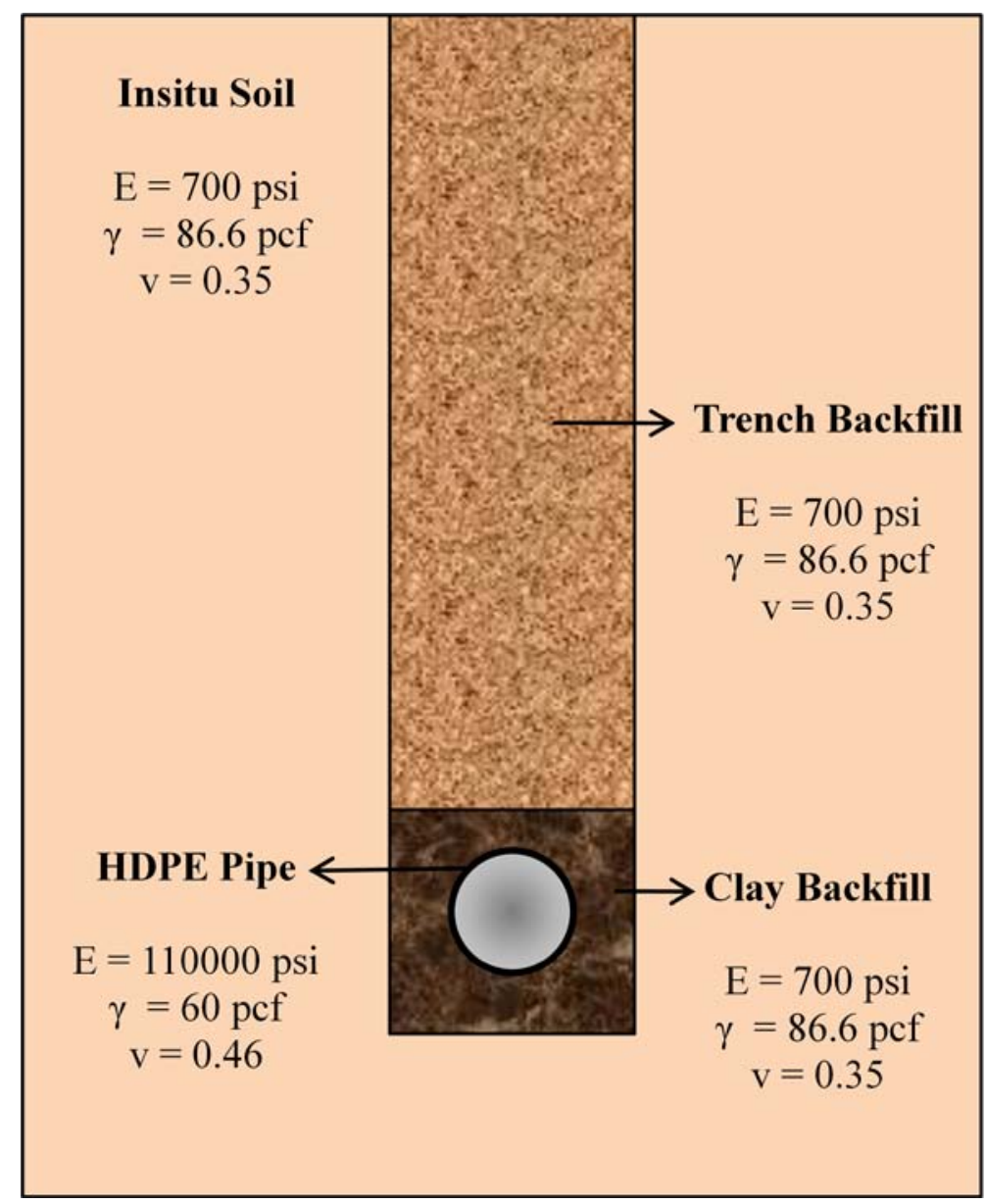

Figure 5.2: Soil and HDPE pipe properties used in the present study 


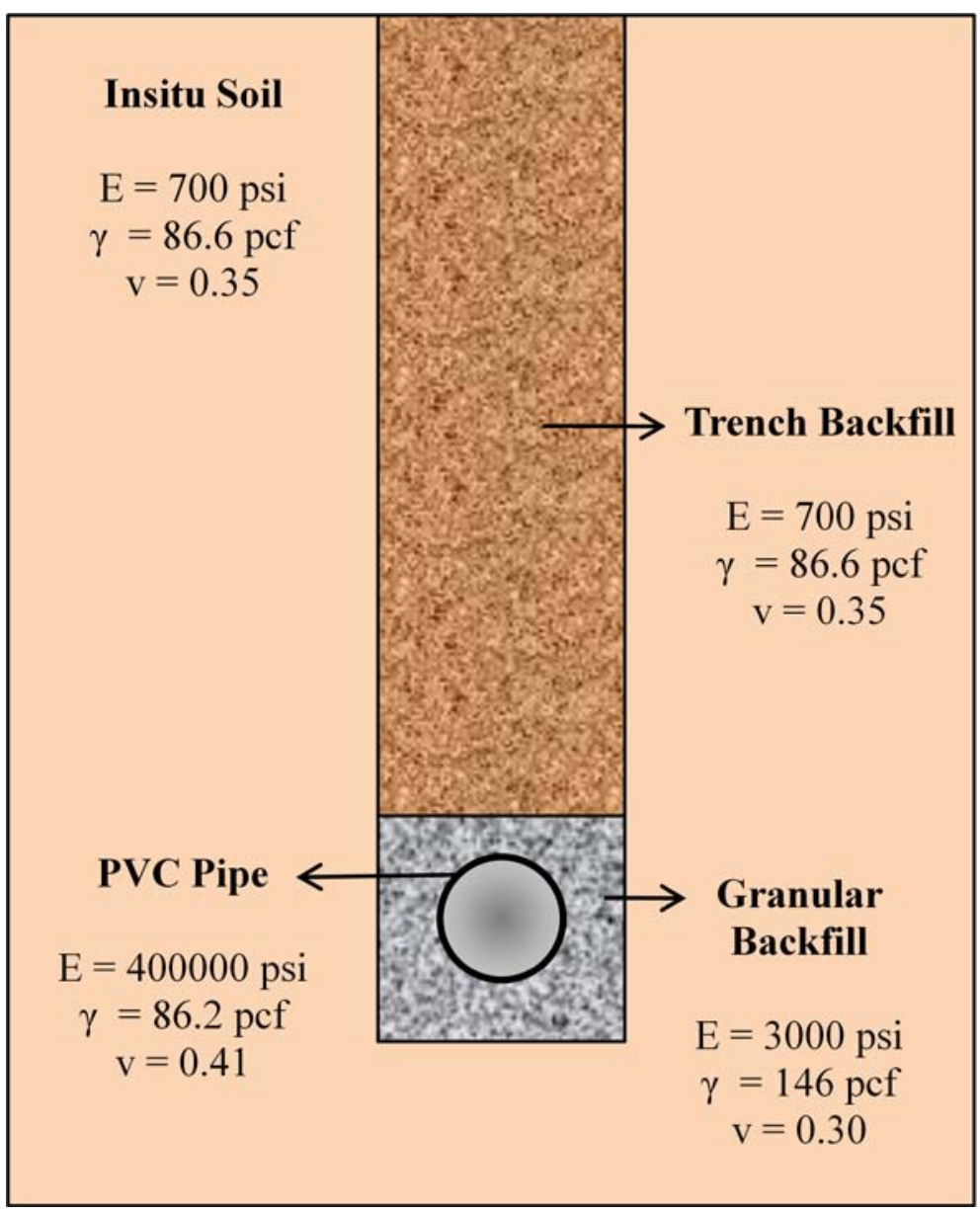

Figure 5.3: Soil and PVC pipe properties used in present study 
Table 5.3: Steps used for trench backfill loading analyses

\begin{tabular}{|c|c|c|c|}
\hline \multicolumn{5}{|c|}{ TRENCH BACKFILL LOADING } \\
\hline Step & Procedure & Time Period (days) & Increment Size \\
\hline Geostatic & Geostatic & -- & -- \\
\hline Trench Excavation & Soils (Transient) & 0.01 & 0.01 \\
\hline Trench Replacement & Soils (Transient) & 0.01 & 0.01 \\
\hline One Day & Soils (Transient) & 1 & 0.05 \\
\hline One Month & Soils (Transient) & 30 & 30 \\
\hline One Year & Soils (Transient) & 360 & 360 \\
\hline Five Years & Soils (Transient) & 1800 & 1800 \\
\hline Fifty Years & Soils (Transient) & 18000 & \\
\hline
\end{tabular}


Table 5.4: Steps used for embankment loading analyses

\begin{tabular}{|c|c|c|c|}
\hline \multicolumn{4}{|c|}{ EMBANKMENT LOADING } \\
\hline Step & Procedure & Time Period (days) & Increment Size \\
\hline Geostatic & Geostatic & -- & -- \\
\hline One Day & Soils (Transient) & 1 & 0.05 \\
\hline One Month & Soils (Transient) & 30 & 1 \\
\hline One Year & Soils (Transient) & 360 & 30 \\
\hline Five Years & Soils (Transient) & 1800 & 1800 \\
\hline Fifty Years & Soils (Transient) & 18000 & \\
\hline
\end{tabular}

\subsubsection{Modeling of Interfaces}

The soil-pipe system shown in Figure 5.4 consists of different parts (i.e., components), and each of these parts were meshed independently. As such, it is necessary to define the interactions between these different parts. Since the soil-pipe system is considered as one single continuous medium, tie interactions were used to join the soil-pipe interfaces, as shown in Figure 5.4(a). The trench backfill was allowed to slip freely against the insitu soil elements. The bottom boundary of the trench backfill was tied to the top boundary of the pipe-backfill. For the embankment loading condition, only the soil-pipe interface was considered, as shown in Figure 5.4(b). 


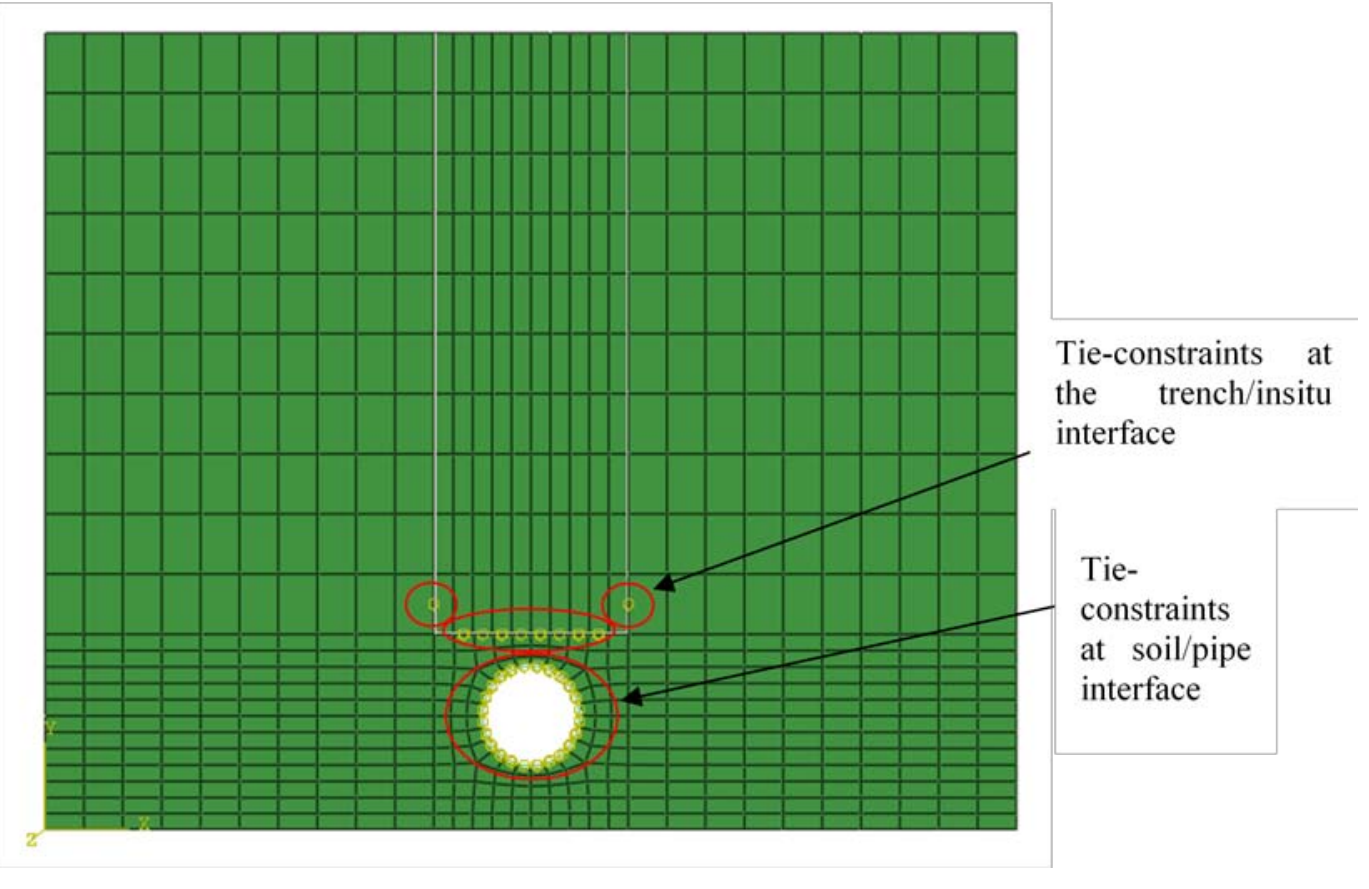

(a) Trench loading

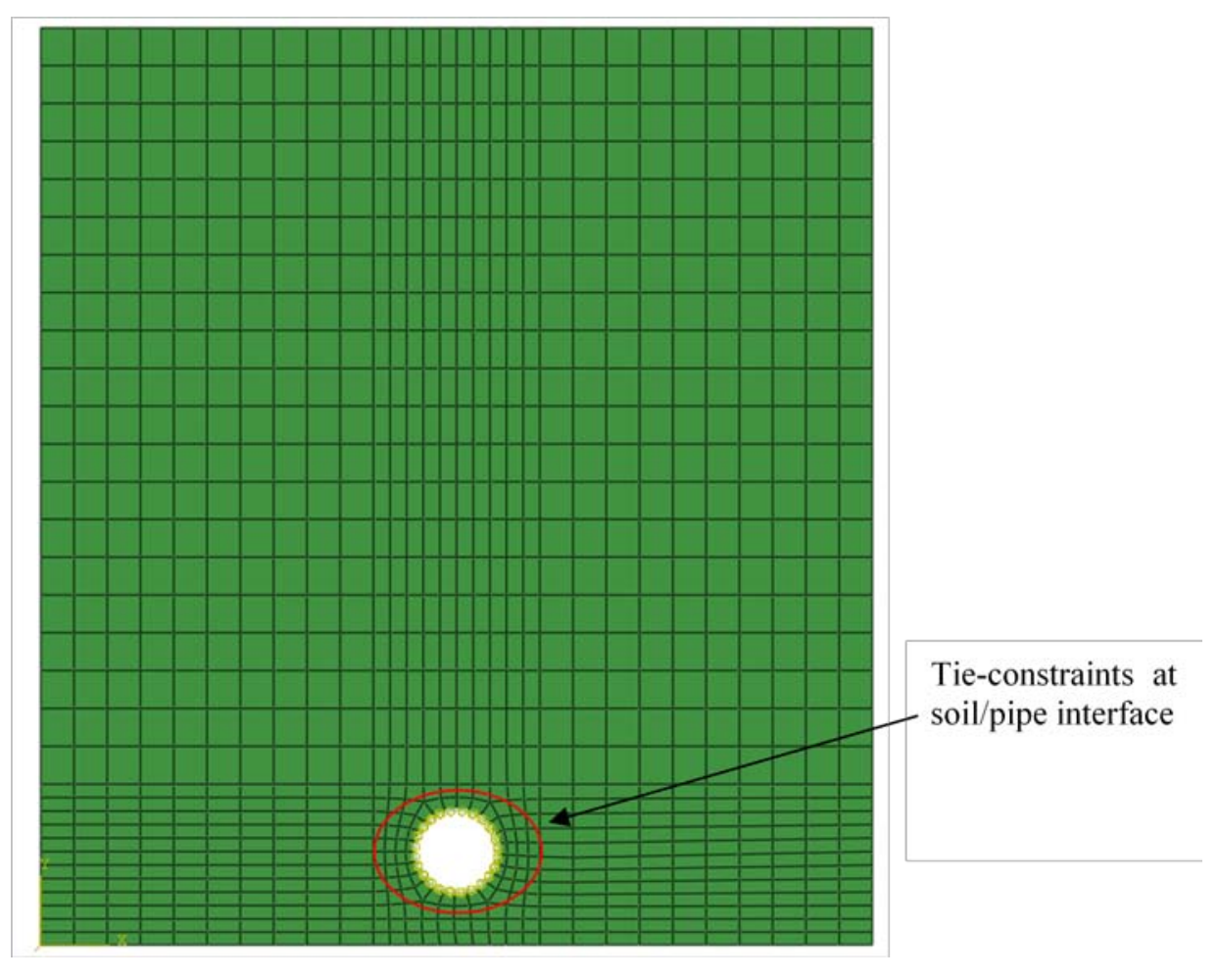

(b) Embankment loading

Figure 5.4: Finite element mesh show interfaces 


\subsubsection{Loading and Boundary Conditions}

A gravity loading was applied throughout the soil to act as the self-weight of the soil, as shown in Figure 5.5. When a saturated soil mass is analyzed, two types of boundary conditions need to be specified: (a) displacement boundary conditions and (b) hydraulic boundary conditions (Helwany, 2007). The vertical component of the displacement is fixed on the bottom and the horizontal component of displacement is fixed on the sides of the model, as shown in Figure 5.5. As shown in this figure, y-symmetry was applied to the elements at the base of the model and x-symmetry was applied to the elements at the sides of the model.

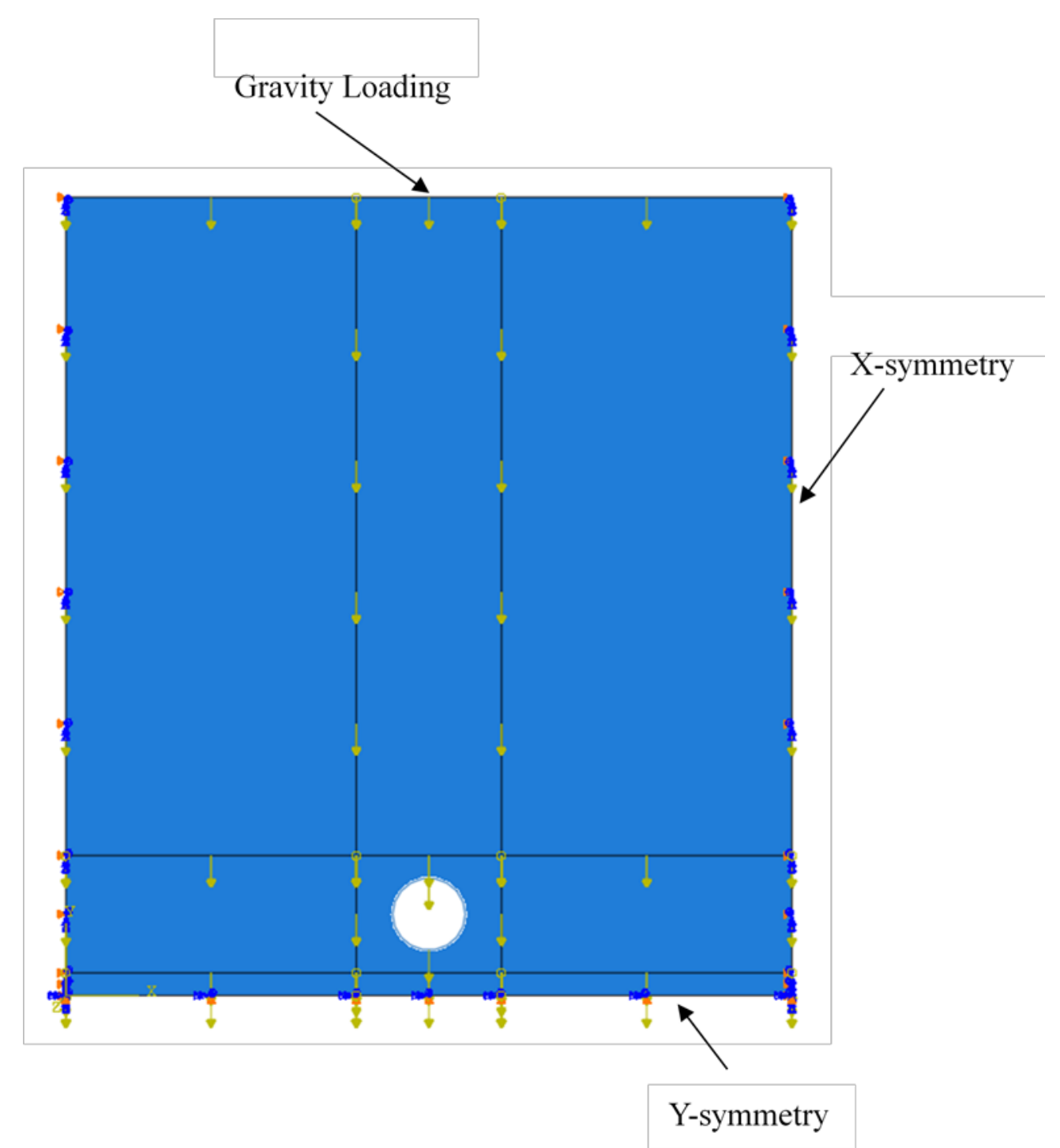

Figure 5.5: Loading and boundary conditions 


\subsubsection{Element Type and Mesh}

Meshing techniques in ABAQUS include structured, swept, and free as discussed elsewhere (Helwany, 2007). In this study, a structured mesh was used to mesh the insitu and trench backfill soils. A free mesh was used for the pipe backfill soil. Four-noded plane-strain, quadrilateral, bilinear displacement, and bilinear pore pressure (CPE4P) elements were used for the soil elements, and 2-noded linear beam (B21) elements were used for the pipe. The CPE4P elements were used for the soil because they can handle both pore fluid and stress. This is necessary for consolidation analysis. Beam elements account for shear, moment, and thrust forces (Desai \& Abel, 1972; Cook et al., 2003).

\subsubsection{Drainage Conditions}

Figure 5.6 shows the drainage boundary conditions used in the analysis. There are two drainage boundaries: (a) surface drainage, and (b) drainage at the pipe-soil interface. The drainage around the pipe causes the pore pressure to dissipate, allowing soil consolidation to occur (Helwany, 2007). A summary of the boundary conditions considered in this research study are shown in Table 5.5. 


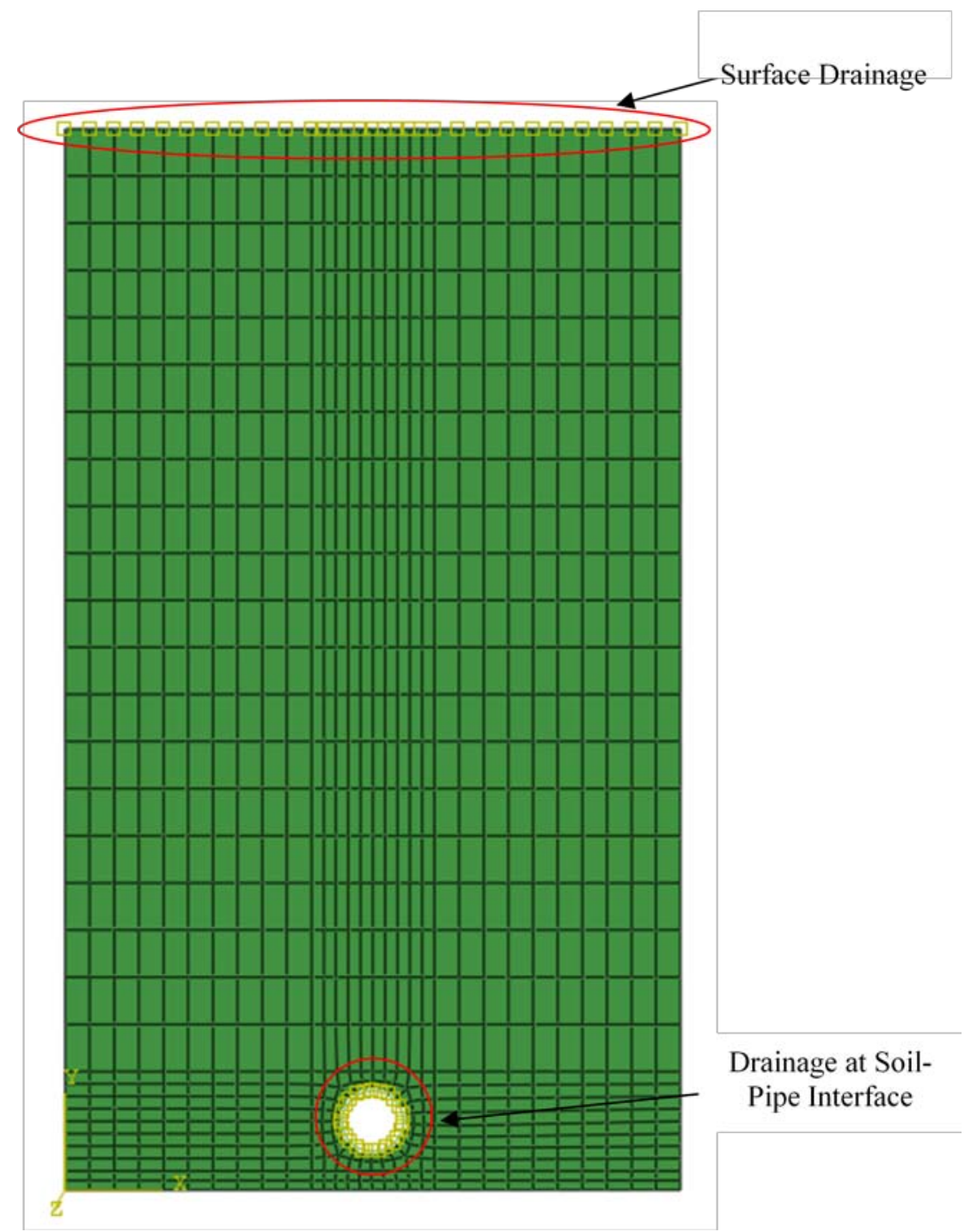

Figure 5.6: Drainage conditions 
Table 5.5: Boundary conditions used in present study

\begin{tabular}{|c|c|}
\hline Step & Description \\
\hline Geostatic & $\begin{array}{l}\text { Equilibrium is obtained; gravity load is } \\
\text { applied. }\end{array}$ \\
\hline Trench Excavation & Removal of trench backfill soil. \\
\hline Trench Replacement & Replacement of trench backfill soil. \\
\hline One Day & \multirow{5}{*}{$\begin{array}{l}\text { Pore pressure dissipates at different rates, } \\
\text { depending on the permeability. } \\
\text { The pipe continues to creep throughout the } \\
\text { duration of the } 50 \text { years. }\end{array}$} \\
\hline One Month & \\
\hline One Year & \\
\hline Five Years & \\
\hline Fifty Years & \\
\hline
\end{tabular}




\subsection{Creep Analysis}

The creep of the pipe is the main time-dependent component considered in this study. The method of analysis for the creep procedure is described below. The properties shown in Tables 5.6 and 5.7 were used in this study. The assembly, steps, time periods, and increment sizes are the same as the creep and consolidation analysis. However, the procedure used for the creep analysis is the 'visco' procedure (Simulia, 2010). Tables 5.8 and 5.9 show these steps. The interaction process is also the same as the creep and consolidation analysis presented in the previous section (refer to Figure 5.4).

The loading and boundary conditions were the same as in the previous analysis, as shown in Figure 5.5. Drainage conditions were not considered. Four-noded plane strain, quadrilateral, reduced integration (CPE4R) elements were used for the soil elements, and 2-noded linear beam (B21) elements were used for the pipe. 
Table 5.6: Soil properties used in current study

\begin{tabular}{|c|c|c|c|c|}
\hline Soil Type & & $\begin{array}{c}\text { Elastic } \\
\text { Modulus, } \\
\text { psi } \\
\left(\mathbf{k N} / \mathbf{m}^{2}\right)\end{array}$ & $\begin{array}{c}\text { Poisson's } \\
\text { Ratio }\end{array}$ & $\begin{array}{c}\text { Dry } \\
\text { Density, } \\
\text { pci } \\
\left(\mathbf{k g} / \mathbf{m}^{3}\right)\end{array}$ \\
\hline Insitu Soil & & $\begin{array}{c}700 \\
(4826)\end{array}$ & 0.35 & $\begin{array}{l}0.0501 \\
(1387)\end{array}$ \\
\hline $\begin{array}{l}\text { Trench } \\
\text { Backfill }\end{array}$ & & $\begin{array}{c}700 \\
(4826)\end{array}$ & 0.35 & $\begin{array}{l}0.0501 \\
(1387)\end{array}$ \\
\hline \multirow[t]{2}{*}{ Pipe Backfill } & Granular & $\begin{array}{c}3000 \\
(20684)\end{array}$ & 0.30 & $\begin{array}{l}0.0845 \\
(2339)\end{array}$ \\
\hline & Clay & $\begin{array}{c}700 \\
(4826)\end{array}$ & 0.35 & $\begin{array}{l}0.0501 \\
(1387)\end{array}$ \\
\hline
\end{tabular}

Table 5.7: Pipe properties used in current study

\begin{tabular}{|c|c|c|c|c|c|c|}
\hline & & & & \multicolumn{3}{|c|}{ Creep Parameters } \\
\hline $\begin{array}{c}\text { Pipe } \\
\text { Material }\end{array}$ & $\begin{array}{c}\text { Density, } \\
\text { pci } \\
\left(\mathrm{kg} / \mathrm{m}^{3}\right)\end{array}$ & $\begin{array}{c}\text { Elastic Modulus, } \\
\text { psi } \\
\left(\mathbf{k N} / \mathbf{m}^{2}\right)\end{array}$ & $\begin{array}{c}\text { Poisson's } \\
\text { Ratio }\end{array}$ & A & $\mathbf{n}$ & $\mathbf{m}$ \\
\hline PVC & $\begin{array}{l}0.0499 \\
(1381)\end{array}$ & $\begin{array}{c}400000 \\
(2757903)\end{array}$ & 0.41 & $1.723 \times 10^{-7}$ & 1 & -0.9433 \\
\hline HDPE & $\begin{array}{c}0.0347 \\
(960)\end{array}$ & $\begin{array}{l}\text { Dependent on } \\
\text { pipe diameter }\end{array}$ & 0.46 & $1.665 \times 10^{-6}$ & 1 & -0.9141 \\
\hline
\end{tabular}


Table 5.8: Trench loading time steps used for creep analysis

\begin{tabular}{|c|c|c|c|}
\hline \multicolumn{5}{|c|}{ TRENCH BACKFILL LOADING } \\
\hline Step & Procedure & Time Period & Increment Size \\
\hline Geostatic & Geostatic & -- & - - \\
\hline Trench Excavation & Visco & 0.01 & 0.01 \\
\hline Trench Replacement & Visco & 0.01 & 0.01 \\
\hline One Day & Visco & 1 & 1800 \\
\hline One Month & Visco & 30 & 30 \\
\hline Fifty Years & Visco & 18000 & 360 \\
\hline Five Years & Visco & & \\
\hline
\end{tabular}


Table 5.9: Embankment loading time steps used for creep analysis

\begin{tabular}{|c|c|c|c|}
\hline \multicolumn{4}{|c|}{ EMBANKMENT LOADING } \\
\hline Step & Procedure & Time Period & Increment Size \\
\hline Geostatic & Geostatic & -- & -- \\
\hline One Day & Visco & 1 & 0.05 \\
\hline One Month & Visco & 30 & 1 \\
\hline One Year & Visco & 360 & 30 \\
\hline Five Years & Visco & 1800 & 360 \\
\hline Fifty Years & Visco & 18000 & 1800 \\
\hline
\end{tabular}




\section{CHAPTER 6: RESULTS AND DISCUSSIONS}

\subsection{Introduction}

This research study involved the use of two-dimensional finite element analysis in order to evaluate the long-term performance of double-corrugated HDPE pipes and solid-wall PVC pipes influenced by creep of pipe material and consolidating soil medium. Time-dependent analyses were performed on 24-inch to 60-inch HDPE pipes and 18-inch to 24-inch PVC pipes. Backfill heights ranging from 10 feet to 50 feet were selected. When the trench backfill height was 10 feet to 20 feet, a trench excavation and replacement procedure was performed. Embankment loading was simulated on backfill heights ranging from 30 feet to 50 feet. Two pipe backfill materials, namely granular stone and clay, were considered. The deflection of the pipe undergoing creep was studied and compared with the pipe deflecting under the influence of both creep of the pipe and soil consolidation. Trench-width ratios (see Chapter 1 for definition) ranging from 1.5 to 2.5 were selected.

\subsection{Results of HDPE Pipes Influenced by Creep and Soil Consolidation}

Analyses were performed on 24-inch, 36-inch, 48-inch, and 60-inch diameter double-wall corrugated HDPE pipes under a gravity loading (simulating the self-weight of the soil). Backfill heights of 10 feet, 20 feet, 30 feet, and 50 feet were considered, as well as trench-width ratios of 1.5, 2.0, and 2.5. The deformation of HDPE pipe caused by the combination of creep of the pipe material and the consolidation of soil around the pipe was the focus of this study. These deformations were compared to the deformations caused only by the creep of the HDPE pipe material. In this section, the response of a 60-inch double-corrugated HDPE pipe buried under different trench-width ratios, trench backfill heights, and pipe backfill material (granular and clay) is presented. Summary of results for other pipe sizes is given in this section. Table 6.1 shows the case studies performed on HDPE pipes buried in clay. Table 6.2 shows the case studies performed on HDPE pipes buried in granular stone. These case studies were performed based on two separate loading conditions (loading due to trench backfill and due to embankment construction) and details are given below. 
Table 6.1: Case studies for HDPE pipe placed in clay backfill material

\begin{tabular}{|c|c|c|c|c|c|c|c|c|c|c|c|c|c|}
\hline \multicolumn{14}{|c|}{ HDPE Creep + Consolidation Analyses: Clay Pipe Backfill } \\
\hline & \multicolumn{3}{|c|}{$\begin{array}{l}\text { Diameter: 24- } \\
\text { inch }\end{array}$} & \multicolumn{3}{|c|}{$\begin{array}{l}\text { Diameter: 36- } \\
\text { inch }\end{array}$} & \multicolumn{3}{|c|}{$\begin{array}{c}\text { Diameter: 48- } \\
\text { inch }\end{array}$} & \multicolumn{3}{|c|}{$\begin{array}{c}\text { Diameter: 60- } \\
\text { inch }\end{array}$} & \multirow{2}{*}{ \# of Cases } \\
\hline $\begin{array}{c}\text { Trench-Width } \\
\text { Ratio }\end{array}$ & 1.5 & 2.0 & 2.5 & 1.5 & 2.0 & 2.5 & 1.5 & 2.0 & 2.5 & 1.5 & 2.0 & 2.5 & \\
\hline Depth: 10 feet & $\mathrm{X}$ & $\mathrm{X}$ & $\mathrm{X}$ & $\mathrm{X}$ & $\mathrm{X}$ & $\mathrm{X}$ & $\mathrm{X}$ & $\mathrm{X}$ & $\mathrm{X}$ & $\mathrm{X}$ & $\mathrm{X}$ & $\mathrm{X}$ & 12 \\
\hline Depth: 20 feet & $\mathrm{X}$ & $\mathrm{X}$ & $\mathrm{X}$ & $\mathrm{X}$ & $\mathrm{X}$ & $\mathrm{X}$ & $\mathrm{X}$ & $\mathrm{X}$ & $\mathrm{X}$ & $\mathrm{X}$ & $\mathrm{X}$ & $\mathrm{X}$ & 12 \\
\hline Depth: 30 feet & $\mathrm{X}$ & $\mathrm{X}$ & $\mathrm{X}$ & $\mathrm{X}$ & $\mathrm{X}$ & $\mathrm{X}$ & $\mathrm{X}$ & $\mathrm{X}$ & $\mathrm{X}$ & $\mathrm{X}$ & $\mathrm{X}$ & $\mathrm{X}$ & 12 \\
\hline Depth: 50 feet & $\mathrm{X}$ & $\mathrm{X}$ & $\mathrm{X}$ & $\mathrm{X}$ & $\mathrm{X}$ & $\mathrm{X}$ & $\mathrm{X}$ & $\mathrm{X}$ & $\mathrm{X}$ & $\mathrm{X}$ & $\mathrm{X}$ & $\mathrm{X}$ & 12 \\
\hline
\end{tabular}

Table 6.2: Case studies for HDPE pipe placed in granular stone backfill material

\begin{tabular}{|c|c|c|c|c|c|c|c|c|c|c|c|c|c|}
\hline \multicolumn{14}{|c|}{ HDPE Creep + Consolidation Analyses: Granular Pipe Backfill } \\
\hline & \multicolumn{3}{|c|}{$\begin{array}{l}\text { Diameter: 24- } \\
\text { inch }\end{array}$} & \multicolumn{3}{|c|}{$\begin{array}{l}\text { Diameter: 36- } \\
\text { inch }\end{array}$} & \multicolumn{3}{|c|}{$\begin{array}{c}\text { Diameter: 48- } \\
\text { inch }\end{array}$} & \multicolumn{3}{|c|}{$\begin{array}{l}\text { Diameter: 60- } \\
\text { inch }\end{array}$} & \multirow{2}{*}{ \# of Cases } \\
\hline $\begin{array}{c}\text { Trench-Width } \\
\text { Ratio }\end{array}$ & 1.5 & 2.0 & 2.5 & 1.5 & 2.0 & 2.5 & 1.5 & 2. & 2. & 1.5 & 2.0 & 2.5 & \\
\hline Depth: 10 feet & $\mathrm{X}$ & $\mathrm{X}$ & $\mathrm{X}$ & $\mathrm{X}$ & $\mathrm{X}$ & $\mathrm{X}$ & $\mathrm{X}$ & $\mathrm{X}$ & $\mathrm{X}$ & $\mathrm{X}$ & $\mathrm{X}$ & $\mathrm{X}$ & 12 \\
\hline Depth: 20 feet & $\mathrm{X}$ & $\mathrm{X}$ & $\mathrm{X}$ & $\mathrm{X}$ & $\mathrm{X}$ & $\mathrm{X}$ & $\mathrm{X}$ & $\mathrm{X}$ & $\mathrm{X}$ & $\mathrm{X}$ & $\mathrm{X}$ & $\mathrm{X}$ & 12 \\
\hline Depth: 30 feet & $\mathrm{X}$ & $\mathrm{X}$ & $\mathrm{X}$ & $\mathrm{X}$ & $\mathrm{X}$ & $\mathrm{X}$ & $\mathrm{X}$ & $\mathrm{x}$ & $\mathrm{X}$ & $\mathrm{X}$ & $\mathrm{X}$ & $\mathrm{X}$ & 12 \\
\hline Depth: 50 feet & $\mathrm{X}$ & $\mathrm{X}$ & $\mathrm{X}$ & $\mathrm{X}$ & $\mathrm{X}$ & $\mathrm{X}$ & $\mathrm{X}$ & $\mathrm{x}$ & $\mathrm{X}$ & $\mathrm{X}$ & $\mathrm{X}$ & $\mathrm{X}$ & 12 \\
\hline
\end{tabular}




\subsubsection{Trench Loading}

Trench backfill loading was considered for backfill heights of 10 feet and 20 feet. Figure 6.1 shows the displacements of a 60-inch diameter HDPE pipe at the end of 50 years for soil influenced by self-weight at a trench-width ratio of 2.0 and a backfill height of 20 feet placed in granular stone backfill material.
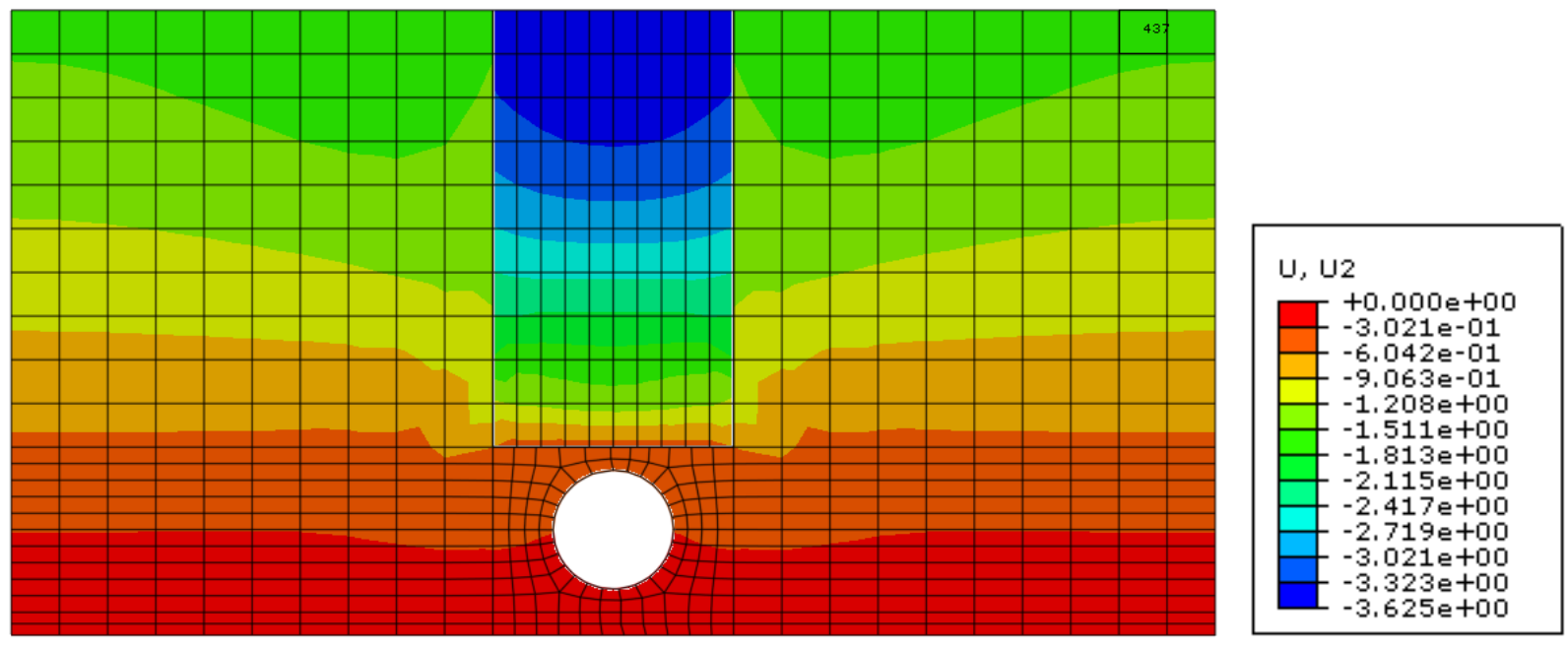

Note: Displacements are given in inches

Figure 6.1: Displacements of a 60-inch HDPE pipe buried in granular material under 20 feet of trench backfill and a trench width ratio of 2.0

\subsubsection{Embankment Loading}

Embankment loading was considered for pipes buried at trench backfill heights of 30 feet and 50 feet. Figure 6.2 shows the 50 year deformation of a 60 -inch diameter HDPE pipe for soil influenced by the self-weight of soil at a trench-width ratio of 2.0 and a backfill height of 50 feet placed in granular stone backfill material. 

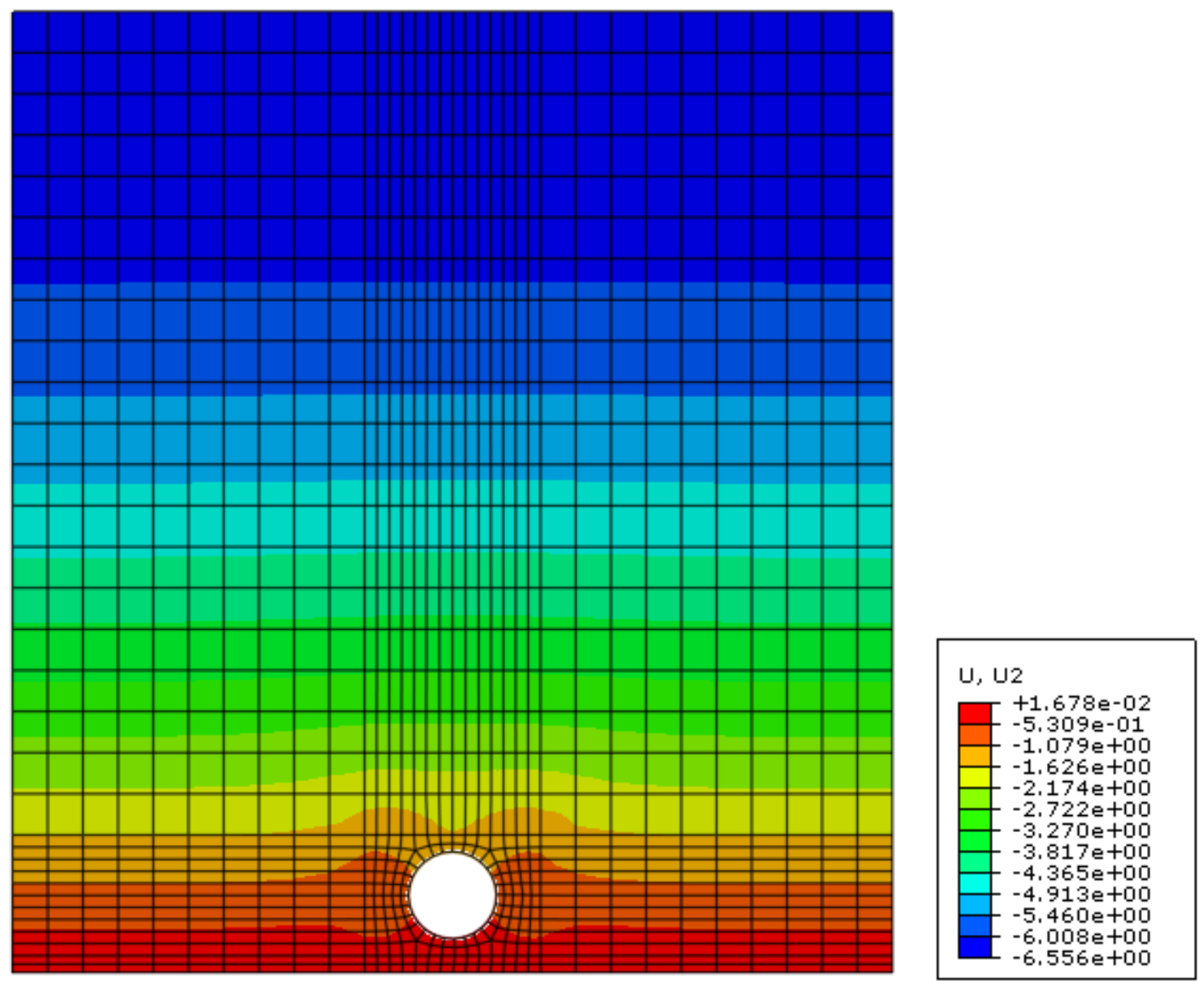

Note: Displacements are given in inches

Figure 6.2: Displacements of a 60-inch HDPE pipe buried in granular material under 50 feet of trench backfill and at a trench width ratio of 2.0

\subsubsection{Influence of Pipe Backfill Material}

A comparison of displacements for a 60-inch diameter HDPE pipe with a trench-width ratio of 2.0 under different backfill materials and backfill heights are presented. Figure 6.3 compares the deflection of HDPE pipe buried in different pipe backfill materials: granular and clay backfill material. As can be seen from this figure, pipes placed in clay material deflect more than pipes placed in granular stone backfill material. Figures 6.4 and 6.5 compare the pipe deflections of an HDPE pipe installed under increasing backfill heights. As the backfill height increases, the deflection of the pipe also increases. 


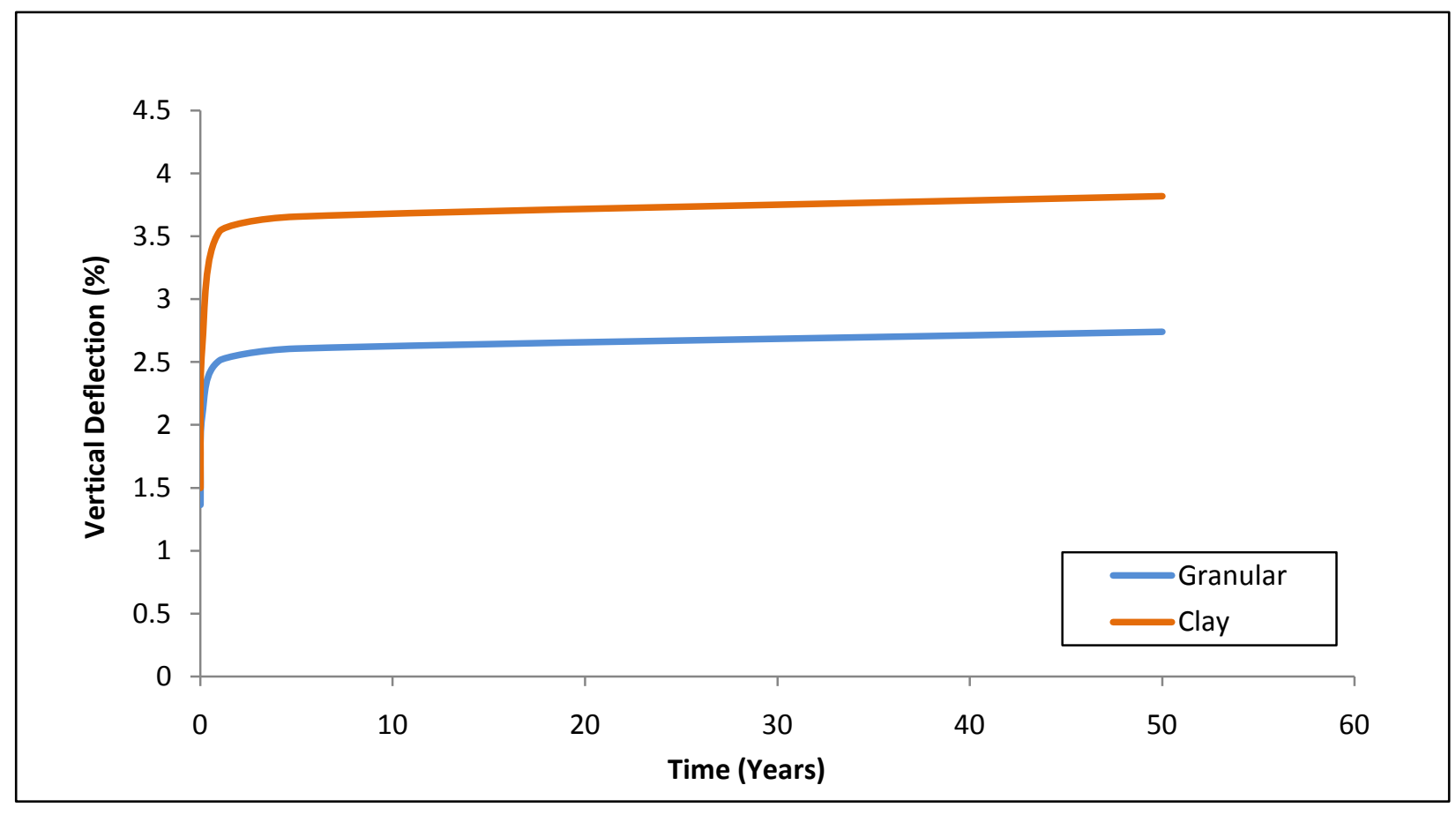

Figure 6.3: Vertical pipe deflection for a 60-inch HDPE pipe installed at a depth of 50 feet

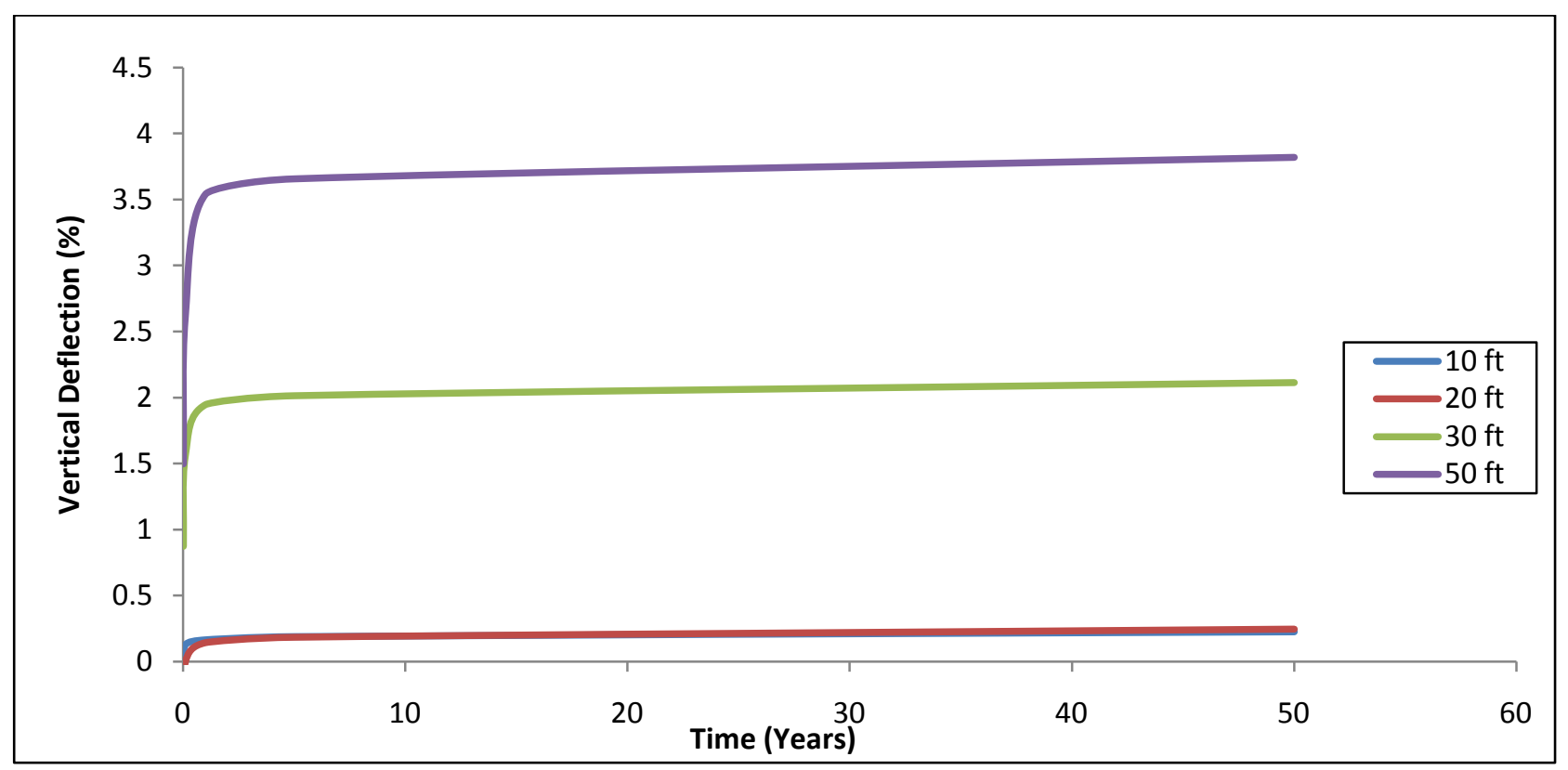

Figure 6.4: Deflections of a 60-inch HDPE pipe with clay backfill material 


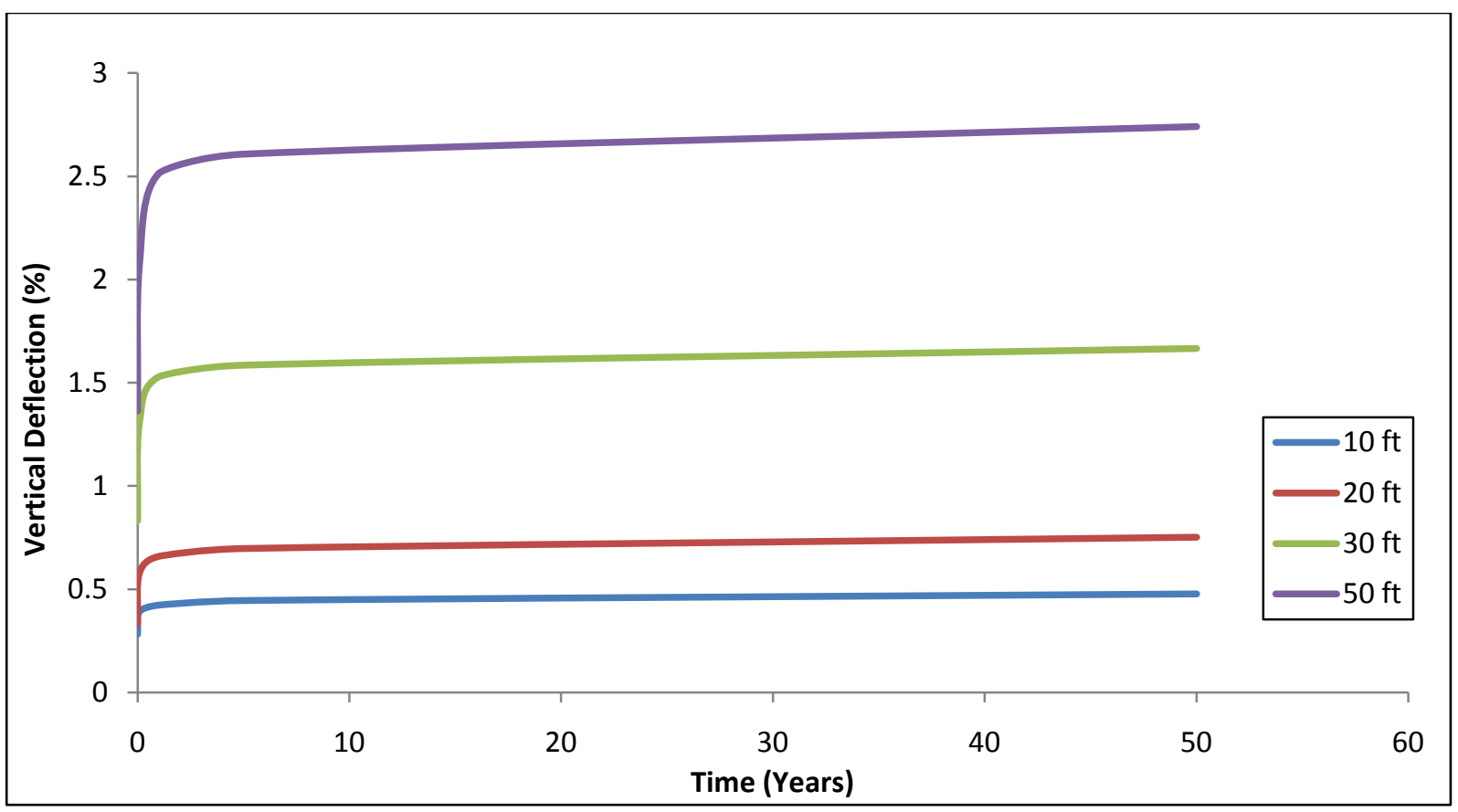

Figure 6.5: Deflections of a 60-inch HDPE pipe with granular stone backfill material

\subsubsection{Influence of Trench-Width Ratio}

Figures 6.6 and 6.7 compare the vertical deflection of the 60-inch HDPE pipe under increasing backfill heights, as well as trench-width ratios of 1.5, 2.0, and 2.5. There is not a significant difference of pipe deflections based upon the trench-width ratio when the pipe is placed in clay backfill. For the HDPE pipe buried in granular material, it can be noted that a greater trench-width ratio gives a lesser deflection. These results indicate that smaller trenchwidth ratios may be used without causing significant increase in pipe deflections. However, the influence of trench width ratio on pipe deflections depends on pipe diameter and the backfill material. 


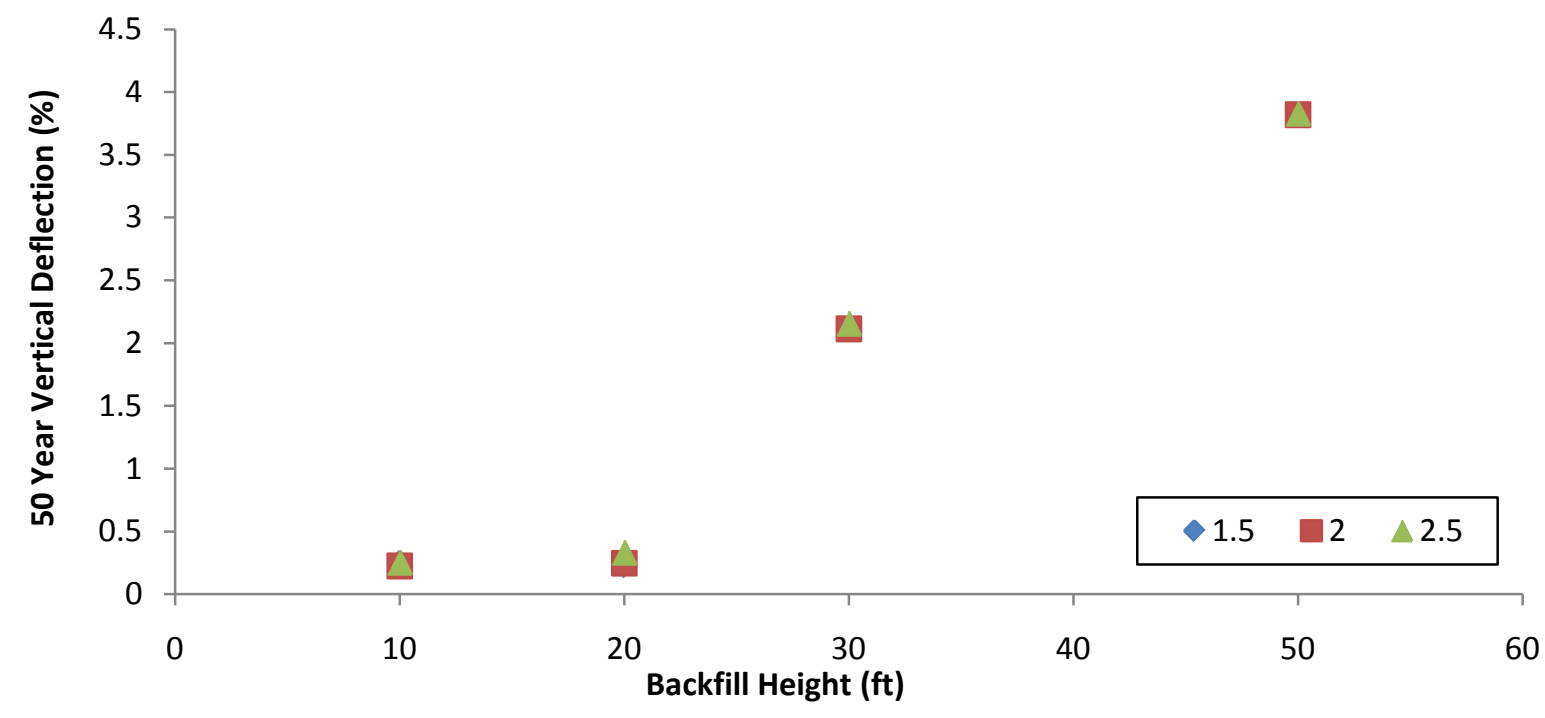

Figure 6.6: Effect of trench-width for a 60-inch HDPE pipe with clay backfill material

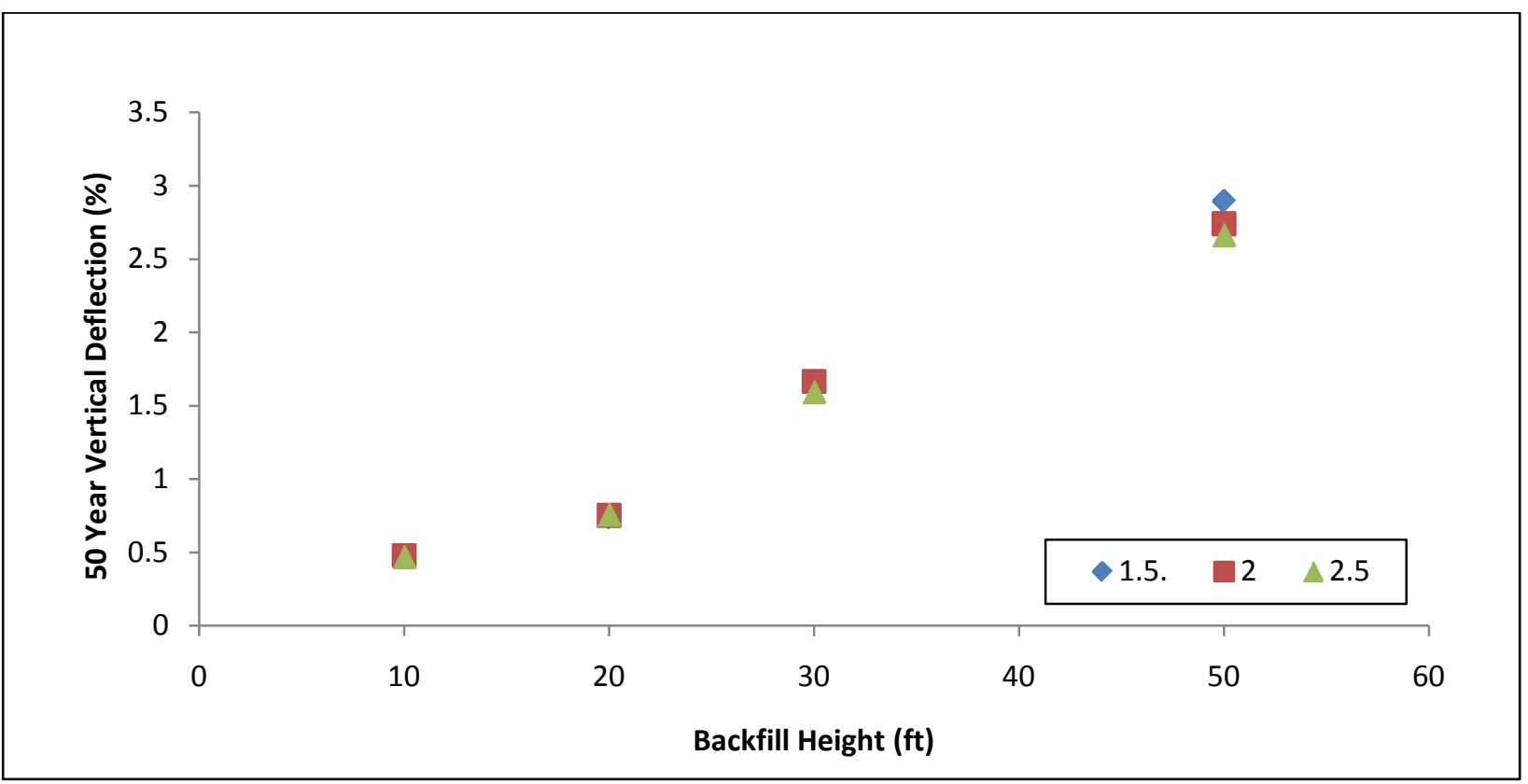

Figure 6.7: Effect of trench-width for a 60-inch HDPE pipe with granular backfill material 


\subsubsection{Influence of Pipe Diameter}

In order to investigate the influence of pipe diameter, a trench width ratio of 2.0 was selected. Figures 6.8 and 6.9 compare the deflection of various HDPE pipe diameters installed at different depths. As expected, the numerical models show that larger diameter pipes deflect more than the smaller diameter pipes. Also, as the backfill height increases, the pipe deflection increases. The pipe deflection did not reach 5\% in any of the cases, which is considered as the failure criterion. These results show that a 60-inch HDPE pipe can be buried to depths as high as 50 feet without causing significant pipe deflections.

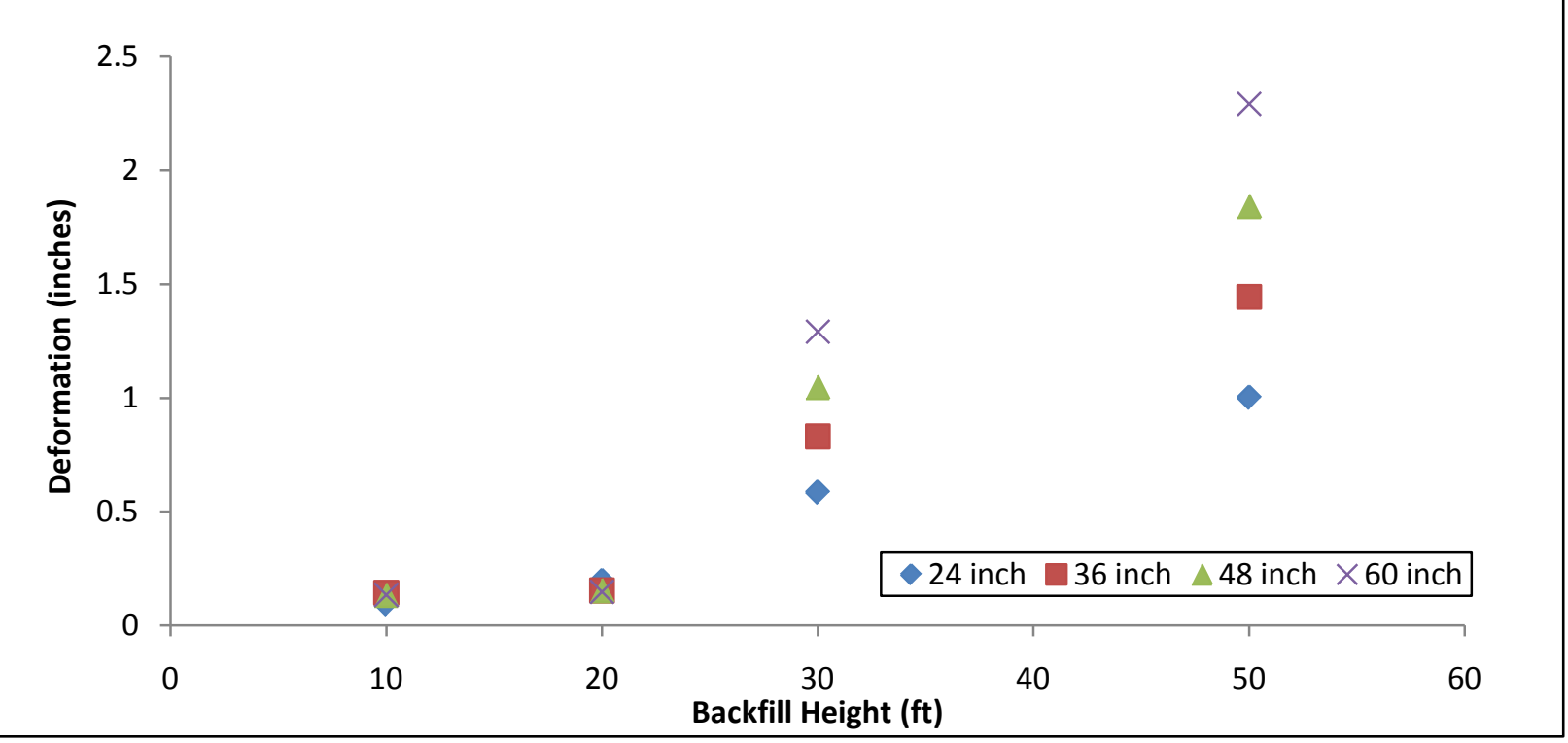

Figure 6.8: Deflection of various HDPE pipe diameters with clay backfill material 


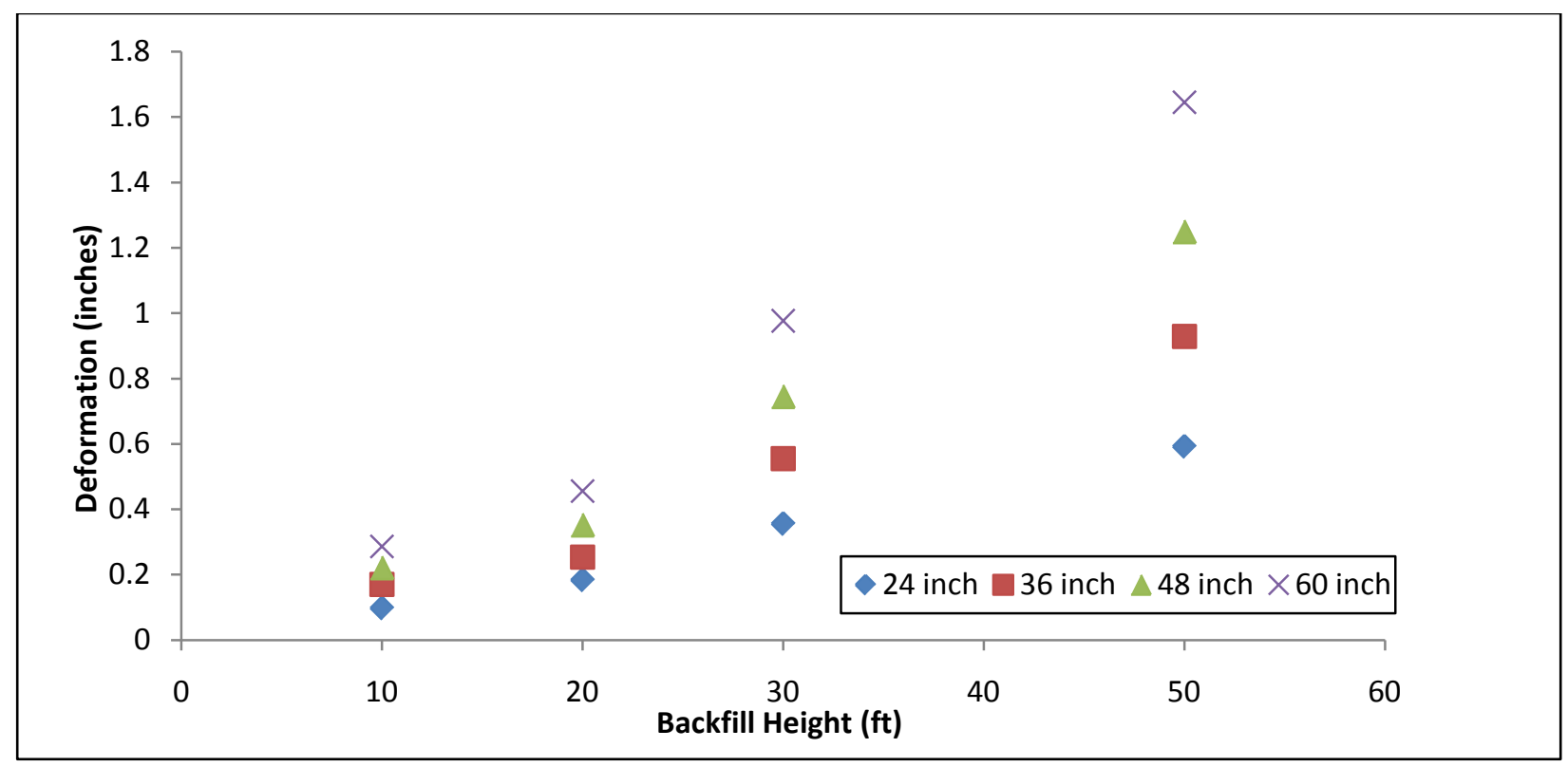

Figure 6.9: Deflection of various HDPE pipe diameters with granular stone

\subsection{Creep Response of HDPE Pipes}

The creep response of a 60-inch double-corrugated HDPE pipe buried under different trench-width ratios, trench backfill heights, and pipe backfill material (granular and clay) is presented in this section. Only a limited number of cases were completed for the creep study since the objective of this study was to investigate the combined influence of creep and consolidation. Results for all of the cases investigated are presented in Appendix B, and a summary is presented below.

A comparison of creep displacements for a 60-inch diameter HDPE pipe with a trenchwidth ratio of 2.0 under different backfill materials and backfill heights are presented for a 50year period in Figures 6.10 to 6.12. Figure 6.10 compares the deflection of HDPE pipe buried in different pipe backfill materials: granular and clay backfill material. As can be seen from this figure, pipes buried in clay material deflect more than pipes buried in granular material. Figures 6.11 and 6.12 compare the pipe deflections of an HDPE pipe installed under increasing backfill heights. As the backfill height increases, the deflection of the pipe also increases. These figures show that the pipe deflections are smaller than 5\% during the 50-year period. 


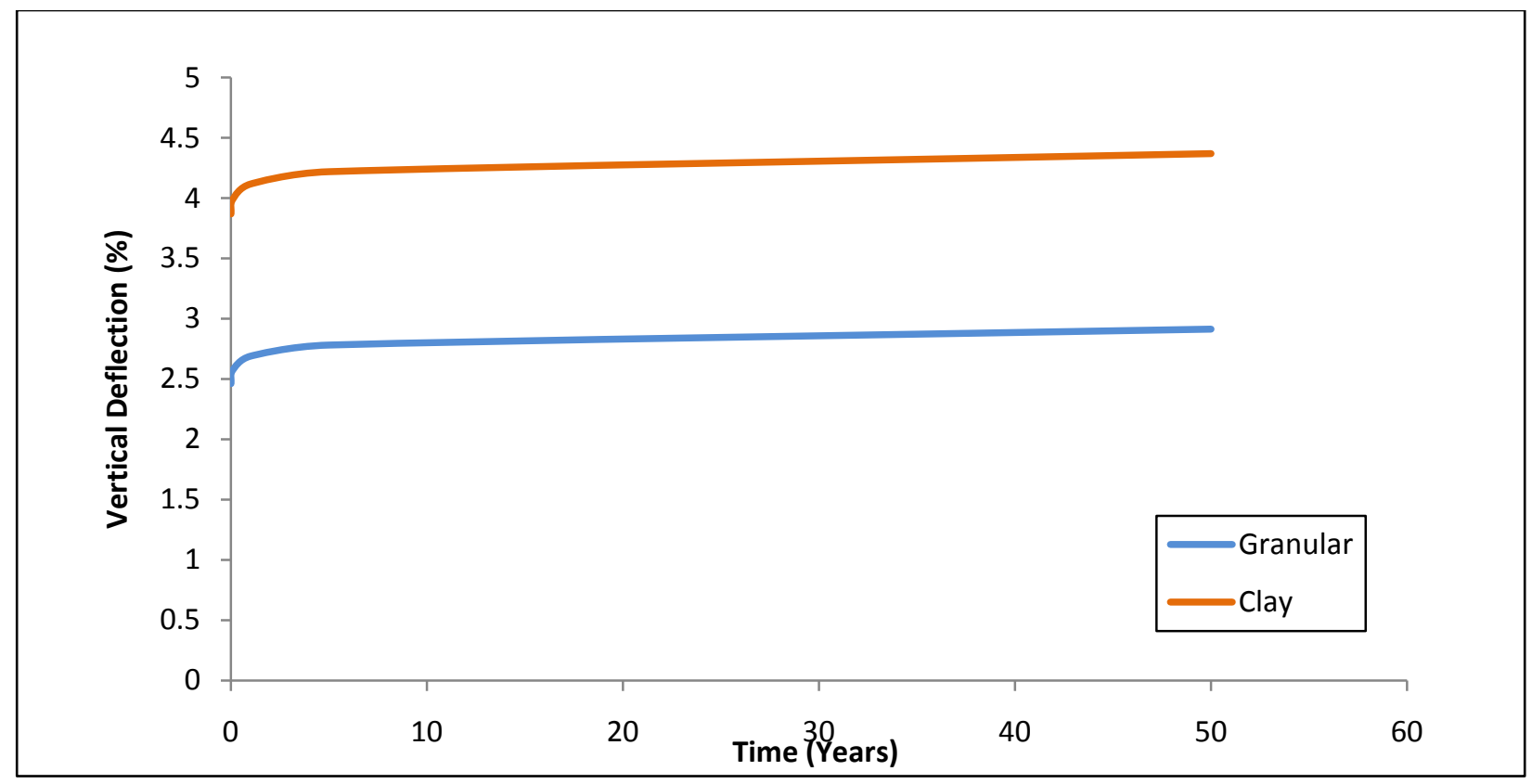

Figure 6.10: Vertical pipe deflection for a 60-inch HDPE pipe installed at a depth of 50 feet

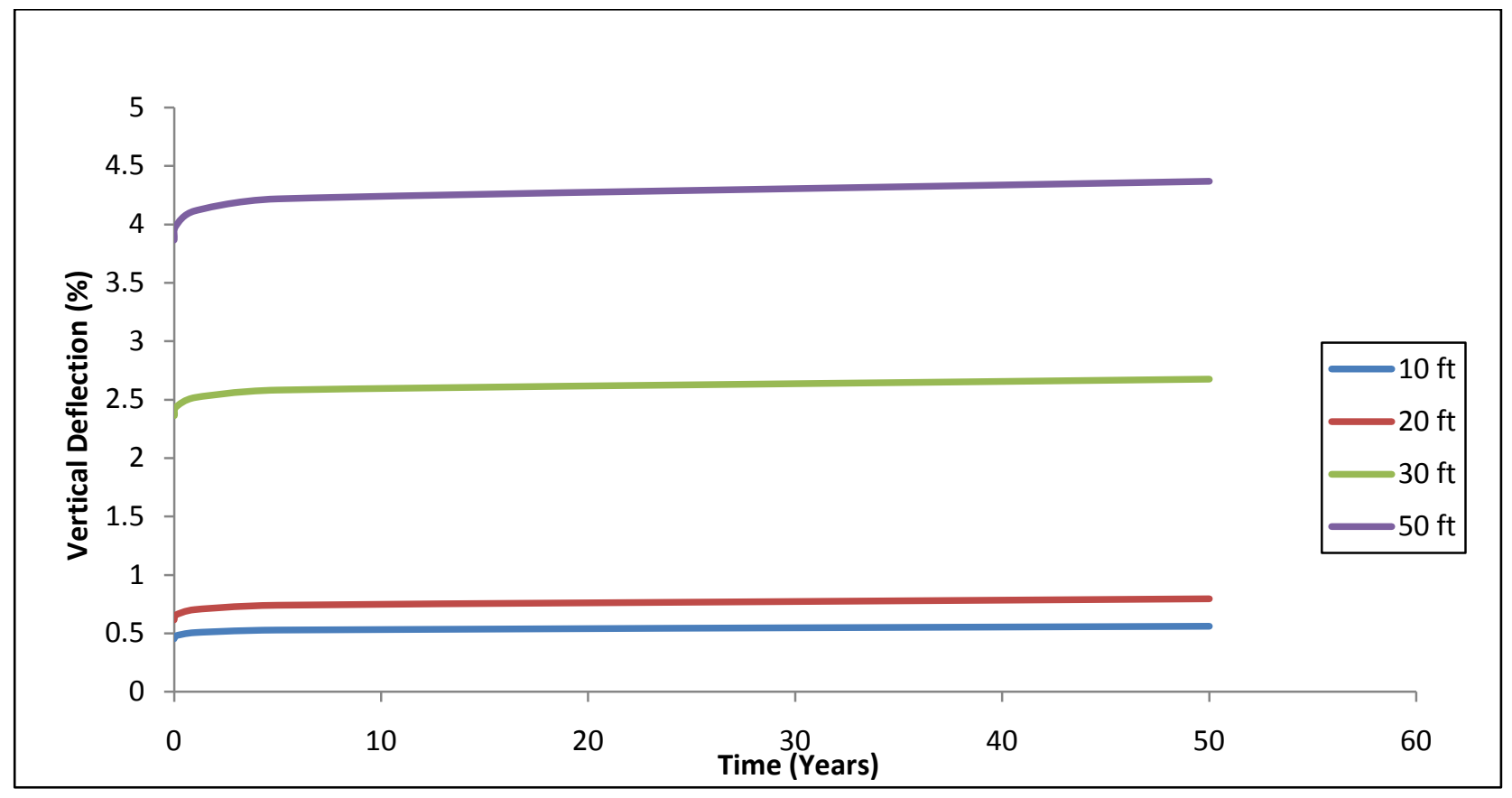

Figure 6.11: Deflections of a 60-inch HDPE pipe with clay backfill material 


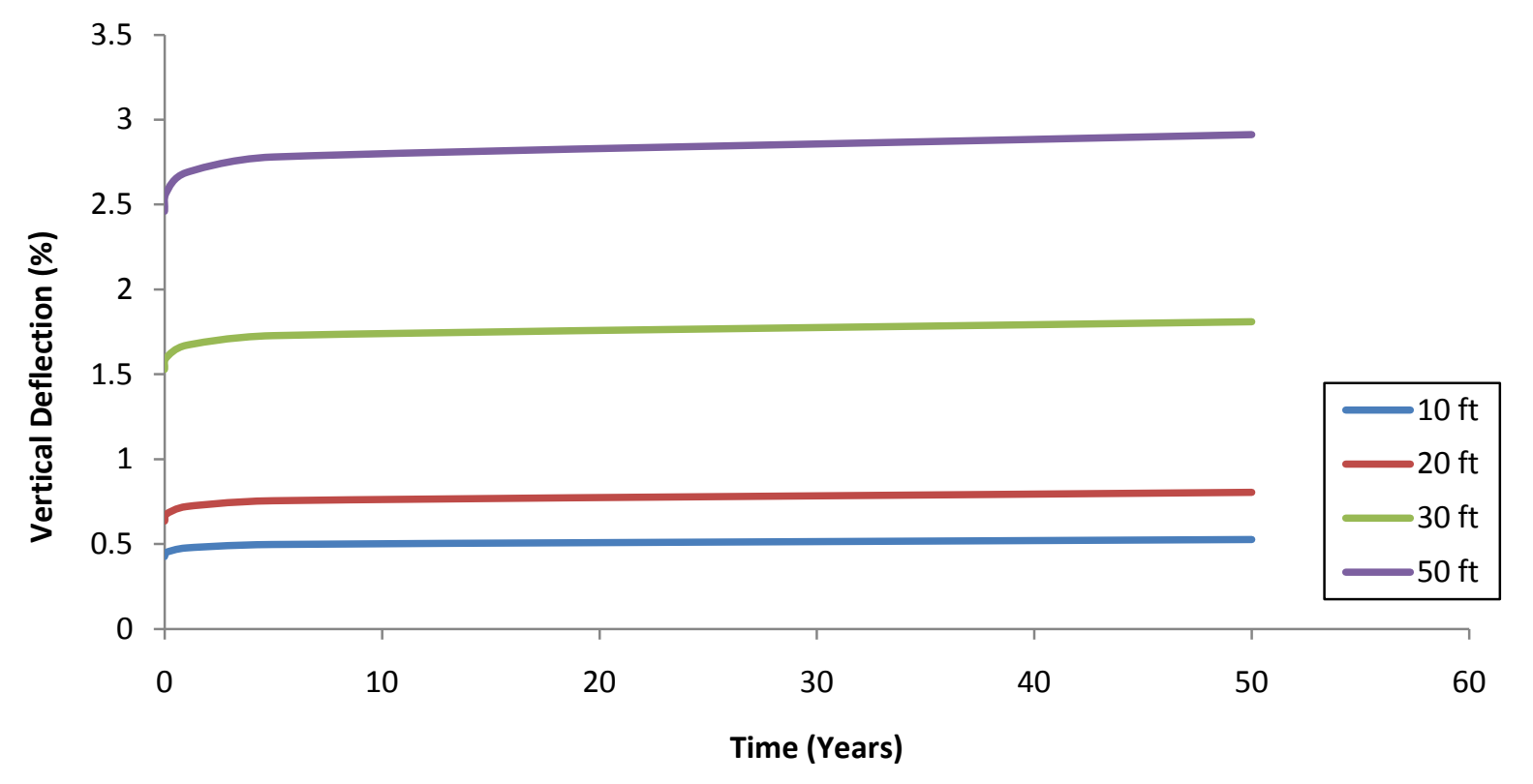

Figure 6.12: Deflections of a 60-inch HDPE pipe with granular stone backfill

\subsection{Combined Influence of Creep and Consolidation}

Figure 6.13 compares the vertical deflection of a 60-inch HDPE pipe under different conditions: (a) only creep of the pipe material and (b) the combined influence of creep and soil consolidation. Buried pipes influenced by both time-dependent properties of creep and soil consolidation have a slightly lesser deflection than those only influenced by creep. This could be due to the fact that the soil weight acts instantaneously on the pipe when there is no consolidation, which in turn gives rise to higher creep rates at the beginning of loading (refer to Appendix B). 


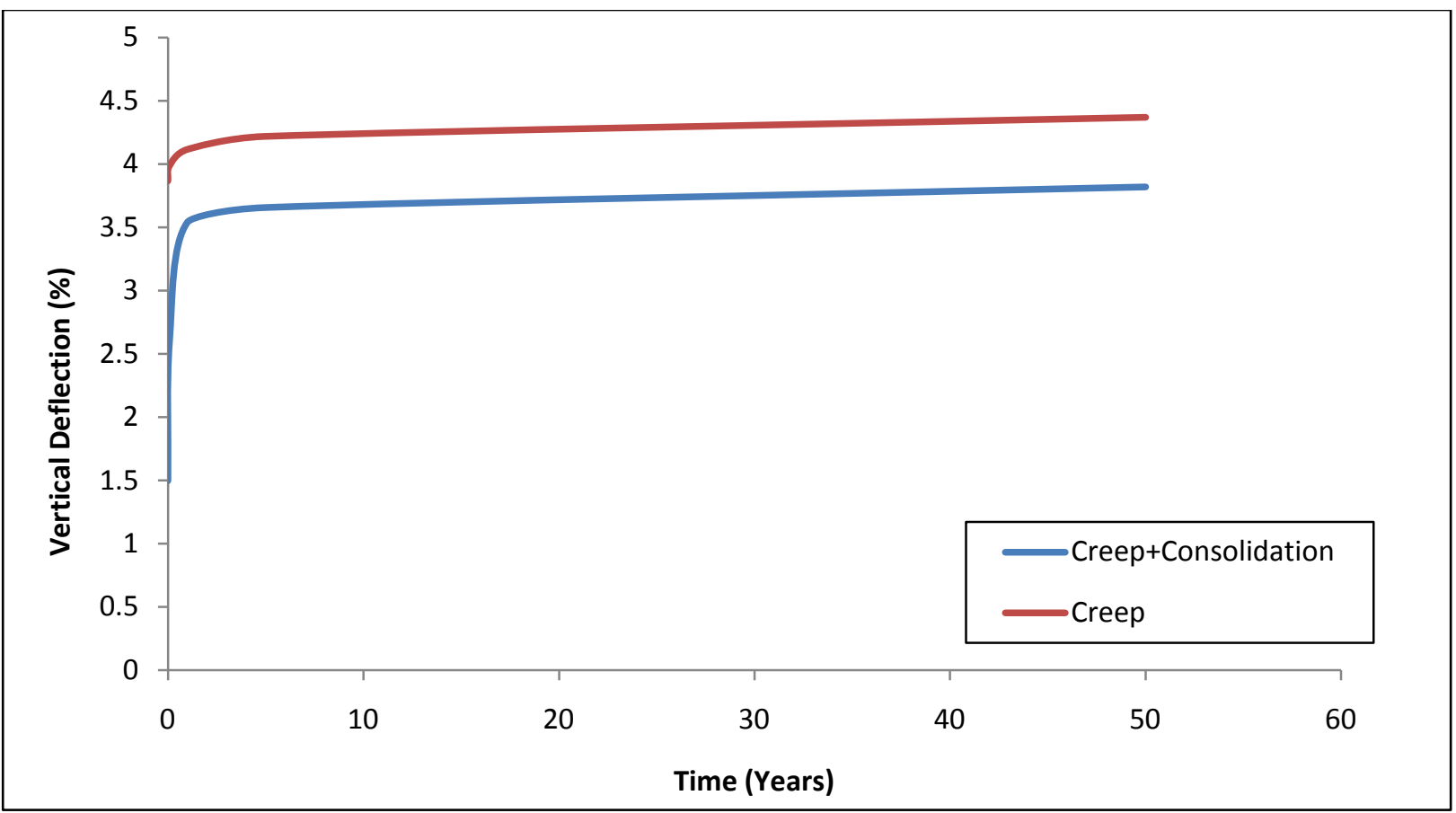

Figure 6.13: Comparison of pipe deflection under trench backfill height of 50 feet with clay backfill

\subsection{Summary of Results for HDPE Pipes}

Analyses of cases shown in Table 6.1 and Table 6.2 were completed in a manner similar to what is presented in the previous section. Table 6.3 shows the pipe deflections for HDPE pipes with clay backfill under the combined influence of creep and consolidation. Table 6.4 shows pipe deflections for the same cases as a percentage of pipe diameters. As can be seen from these tables, none of the pipes reach 5\% pipe deflection under the combined influence of creep and consolidation. As can be seen from these tables, even for the cases corresponding to trench-width ratio of 1.5, the pipes did not reach 5\% deflections under the self-weight of soil. These results suggest the possibility of using smaller trench width ratios. However, the influence of trenchwidth ratio on pipe deflections depends on pipe diameter and the backfill material. 
Table 6.3: Deflection of HDPE pipe (inches)

\begin{tabular}{|c|c|c|c|c|c|c|c|c|c|c|c|c|}
\hline \multicolumn{7}{|c|}{ HDPE Creep + Consolidation Analyses: Clay Pipe Backfill } \\
\hline $\begin{array}{c}\text { Trench- } \\
\text { Width } \\
\text { Ratio }\end{array}$ & 1.5 & 2.0 & 2.5 & 1.5 & 2.0 & 2.5 & 1.5 & 2.0 & 2.5 & 1.5 & 2.0 & 2.5 \\
\hline $\begin{array}{l}\text { Depth: } \\
10 \text { feet }\end{array}$ & 0.110 & 0.095 & 0.093 & 0.138 & 0.145 & 0.126 & 0.254 & 0.135 & 0.174 & 0.148 & 0.135 & 0.153 \\
\hline $\begin{array}{l}\text { Depth: } \\
20 \text { feet }\end{array}$ & 0.165 & 0.198 & 0.131 & 0.173 & 0.154 & 0.183 & 0.151 & 0.155 & 0.206 & 0.138 & 0.148 & 0.200 \\
\hline $\begin{array}{l}\text { Depth: } \\
30 \text { feet }\end{array}$ & 0.585 & 0.586 & 0.586 & 0.832 & 0.831 & 0.831 & 1.07 & 1.05 & 1.05 & 1.27 & 1.29 & 1.29 \\
\hline $\begin{array}{l}\text { Depth: } \\
50 \text { feet }\end{array}$ & 1.00 & 1.00 & 1.00 & 1.44 & 1.44 & 1.44 & 1.89 & 1.84 & 1.84 & 2.29 & 2.29 & 2.29 \\
\hline
\end{tabular}


Table 6.4: Deflection of HDPE pipe (percentage)

\begin{tabular}{|c|c|c|c|c|c|c|c|c|c|c|c|c|}
\hline \multicolumn{1}{|c|}{ HDPE Creep + Consolidation Analyses: Clay Pipe Backfill } \\
\hline \multicolumn{2}{|c|}{ Diameter: 24-inch } & \multicolumn{2}{|c|}{ Diameter: 36-inch } & \multicolumn{2}{c|}{ Diameter: 48-inch } & \multicolumn{3}{|c|}{ Diameter: 60-inch } \\
\hline $\begin{array}{c}\text { Trench- } \\
\text { Width } \\
\text { Ratio }\end{array}$ & 1.5 & 2.0 & 2.5 & 1.5 & 2.0 & 2.5 & 1.5 & 2.0 & 2.5 & 1.5 & 2.0 & 2.5 \\
\hline $\begin{array}{l}\text { Depth: } \\
10 \text { feet }\end{array}$ & 0.458 & 0.396 & 0.388 & 0.383 & 0.403 & 0.350 & 0.529 & 0.281 & 0.363 & 0.247 & 0.225 & 0.255 \\
\hline $\begin{array}{l}\text { Depth: } \\
20 \text { feet }\end{array}$ & 0.688 & 0.825 & 0.546 & 0.481 & 0.428 & 0.508 & 0.315 & 0.323 & 0.429 & 0.230 & 0.247 & 0.333 \\
\hline $\begin{array}{l}\text { Depth: } \\
30 \text { feet }\end{array}$ & 2.438 & 2.442 & 2.442 & 2.311 & 2.308 & 2.308 & 2.229 & 2.188 & 2.188 & 2.117 & 2.150 & 2.150 \\
\hline $\begin{array}{l}\text { Depth: } \\
50 \text { feet }\end{array}$ & 4.167 & 4.167 & 4.167 & 4.000 & 4.000 & 4.000 & 3.938 & 3.833 & 3.833 & 3.817 & 3.817 & 3.817 \\
\hline
\end{tabular}

Table 6.5 shows the pipe deflections for HDPE pipes with granular stone backfill under the combined influence of creep and consolidation. Table 6.6 shows pipe deflections for the same cases as a percentage of pipe diameters. As can be seen from these tables, none of the pipes with granular stone backfill reach 5\% pipe deflection under the combined influence of creep and consolidation. The conclusions that can be drawn from the results for granular backfill materials are similar to those for clay backfill materials, and none of the pipes reach $5 \%$ pipe deflections under the self-weight of soil. 
Table 6.5: Deflection of HDPE pipe (inches)

\begin{tabular}{|c|c|c|c|c|c|c|c|c|c|c|c|c|}
\hline \multicolumn{7}{|c|}{ HDPE Creep + Consolidation Analyses: Granular Pipe Backfill } \\
\hline \multicolumn{1}{|c|}{ Diameter: 24-inch } & \multicolumn{2}{c|}{ Diameter: 36-inch } & \multicolumn{2}{c|}{ Diameter: 48-inch } & \multicolumn{3}{|c|}{ Diameter: 60 -inch } \\
\hline $\begin{array}{l}\text { Wrench- } \\
\text { Ratio }\end{array}$ & 1.5 & 2.0 & 2.5 & 1.5 & 2.0 & 2.5 & 1.5 & 2.0 & 2.5 & 1.5 & 2.0 & 2.5 \\
\hline $\begin{array}{l}\text { Depth: } \\
10 \text { feet }\end{array}$ & 0.111 & 0.098 & 0.093 & 0.166 & 0.170 & 0.156 & 0.389 & 0.221 & 0.244 & 0.284 & 0.287 & 0.283 \\
\hline $\begin{array}{l}\text { Depth: } \\
20 \text { feet }\end{array}$ & 0.200 & 0.184 & 0.152 & 0.276 & 0.254 & 0.256 & 0.359 & 0.352 & 0.360 & 0.443 & 0.451 & 0.456 \\
\hline $\begin{array}{l}\text { Depth: } \\
30 \text { feet }\end{array}$ & 0.385 & 0.356 & 0.342 & 0.589 & 0.555 & 0.540 & 0.804 & 0.745 & 0.728 & 1.00 & 0.977 & 0.957 \\
\hline $\begin{array}{l}\text { Depth: } \\
50 \text { feet }\end{array}$ & 0.645 & 0.592 & 0.566 & 0.993 & 0.929 & 0.900 & 1.36 & 1.25 & 1.21 & 1.74 & 1.64 & 1.60 \\
\hline
\end{tabular}


Table 6.6: Deflection of HDPE pipe (percentage)

\begin{tabular}{|c|c|c|c|c|c|c|c|c|c|c|c|c|}
\hline \multicolumn{7}{|c|}{ HDPE Creep + Consolidation Analyses: Granular Pipe Backfill } \\
\hline \multicolumn{1}{|c|}{ Diameter: 24-inch } & \multicolumn{2}{c|}{ Diameter: 36-inch } & \multicolumn{2}{c|}{ Diameter: 48-inch } & \multicolumn{3}{|c|}{ Diameter: 60 -inch } \\
\hline $\begin{array}{l}\text { Wrench- } \\
\text { Ratio }\end{array}$ & 1.5 & 2.0 & 2.5 & 1.5 & 2.0 & 2.5 & 1.5 & 2.0 & 2.5 & 1.5 & 2.0 & 2.5 \\
\hline $\begin{array}{l}\text { Depth: } \\
10 \text { feet }\end{array}$ & 0.463 & 0.408 & 0.388 & 0.461 & 0.472 & 0.433 & 0.810 & 0.460 & 0.508 & 0.473 & 0.478 & 0.472 \\
\hline $\begin{array}{l}\text { Depth: } \\
20 \text { feet }\end{array}$ & 0.833 & 0.767 & 0.633 & 0.767 & 0.706 & 0.711 & 0.748 & 0.733 & 0.750 & 0.738 & 0.752 & 0.760 \\
\hline $\begin{array}{l}\text { Depth: } \\
30 \text { feet }\end{array}$ & 1.604 & 1.483 & 1.425 & 1.636 & 1.542 & 1.500 & 1.675 & 1.552 & 1.517 & 1.667 & 1.628 & 1.595 \\
\hline $\begin{array}{l}\text { Depth: } \\
50 \text { feet }\end{array}$ & 2.688 & 2.467 & 2.358 & 2.758 & 2.581 & 2.500 & 2.833 & 2.604 & 2.521 & 2.900 & 2.733 & 2.667 \\
\hline
\end{tabular}




\subsection{Results of Solid-Wall PVC Pipes Influenced by Creep and Soil Consolidation}

Analyses were performed on 18-inch and 24-inch diameter solid-wall PVC pipes under a gravity loading (simulating the self-weight of the soil). Backfill heights of 10 feet, 20 feet, 30 feet, and 50 feet were considered, as well as trench-width ratios of 1.5, 2.0, and 2.5. The deformation of PVC pipes caused by the combination of creep of the pipe material and the consolidation of soil around the pipe was the main focus of this study. In this section, the response of a 24-inch solid-wall PVC pipe buried under different trench-width ratios, trench backfill heights, and pipe backfill material (granular and clay) is presented. Summary of results for other pipe sizes is given in this section. Table 6.7 shows the case studies performed on PVC pipes with clay backfill. Table 6.8 shows the case studies performed on PVC pipes with granular stone backfill. These cases were analyzed by using the finite element method for two separate loading conditions (loading due to trench backfill and due to embankment construction) and results are given below. The numerical procedures are presented in an earlier section of this report (see Section 6.2 regarding HDPE pipes).

Table 6.7: Cases for PVC pipe buried in clay and influenced by creep and soil consolidation

\begin{tabular}{|c|c|c|c|c|c|c|c|}
\hline \multicolumn{8}{|c|}{ PVC Creep + Consolidation Analyses: Clay Pipe Backfill } \\
\hline & \multicolumn{3}{|c|}{ Diameter: 18-inch } & \multicolumn{3}{|c|}{ Diameter: 24-inch } & \multirow{2}{*}{ \# of Cases } \\
\hline $\begin{array}{c}\text { Trench-Width } \\
\text { Ratio }\end{array}$ & 1.5 & 2.0 & 2.5 & 1.5 & 2.0 & 2.5 & \\
\hline Depth: 10 feet & $\mathrm{X}$ & $\mathrm{X}$ & $\mathrm{X}$ & $\mathrm{X}$ & $\mathrm{X}$ & $\mathrm{X}$ & 6 \\
\hline Depth: 20 feet & $\mathrm{X}$ & $\mathrm{X}$ & $\mathrm{X}$ & $\mathrm{X}$ & $\mathrm{X}$ & $\mathrm{X}$ & 6 \\
\hline Depth: 30 feet & $\mathrm{X}$ & $\mathrm{X}$ & $\mathrm{X}$ & $\mathrm{X}$ & $\mathrm{X}$ & $\mathrm{X}$ & 6 \\
\hline Depth: 50 feet & $\mathrm{X}$ & $\mathrm{X}$ & $\mathrm{X}$ & $\mathrm{X}$ & $\mathrm{X}$ & $\mathrm{X}$ & 6 \\
\hline
\end{tabular}


Table 6.8: Cases for PVC pipe buried in granular material and influenced by creep and soil consolidation

\begin{tabular}{|c|c|c|c|c|c|c|c|}
\hline \multicolumn{8}{|c|}{ PVC Creep + Consolidation Analyses: Granular Pipe Backfill } \\
\hline & Dial & ter: 1 & inch & Dia & ter: 2 & inch & \multirow{2}{*}{ \# of Cases } \\
\hline $\begin{array}{c}\text { Trench-Width } \\
\text { Ratio }\end{array}$ & 1.5 & 2.0 & 2.5 & 1.5 & 2.0 & 2.5 & \\
\hline Depth: 10 feet & $\mathrm{X}$ & $\mathrm{X}$ & $\mathrm{X}$ & $\mathrm{X}$ & $\mathrm{X}$ & $\mathrm{X}$ & 6 \\
\hline Depth: 20 feet & $\mathrm{X}$ & $\mathrm{X}$ & $\mathrm{X}$ & $\mathrm{X}$ & $\mathrm{X}$ & $\mathrm{X}$ & 6 \\
\hline Depth: 30 feet & $\mathrm{X}$ & $\mathrm{X}$ & $\mathrm{X}$ & $\mathrm{X}$ & $\mathrm{X}$ & $\mathrm{X}$ & 6 \\
\hline Depth: 50 feet & $\mathrm{X}$ & $\mathrm{X}$ & $\mathrm{X}$ & $\mathrm{X}$ & $\mathrm{X}$ & $\mathrm{X}$ & 6 \\
\hline
\end{tabular}




\subsubsection{Trench Loading}

Trench backfill loading was considered for backfill heights of 10 feet and 20 feet. Figure 6.14 shows the displacements of a 24-inch diameter PVC pipe at the end of 50 years for soil influenced by self-weight at a trench-width ratio of 2.0 and a backfill height of 20 feet with granular stone backfill material.
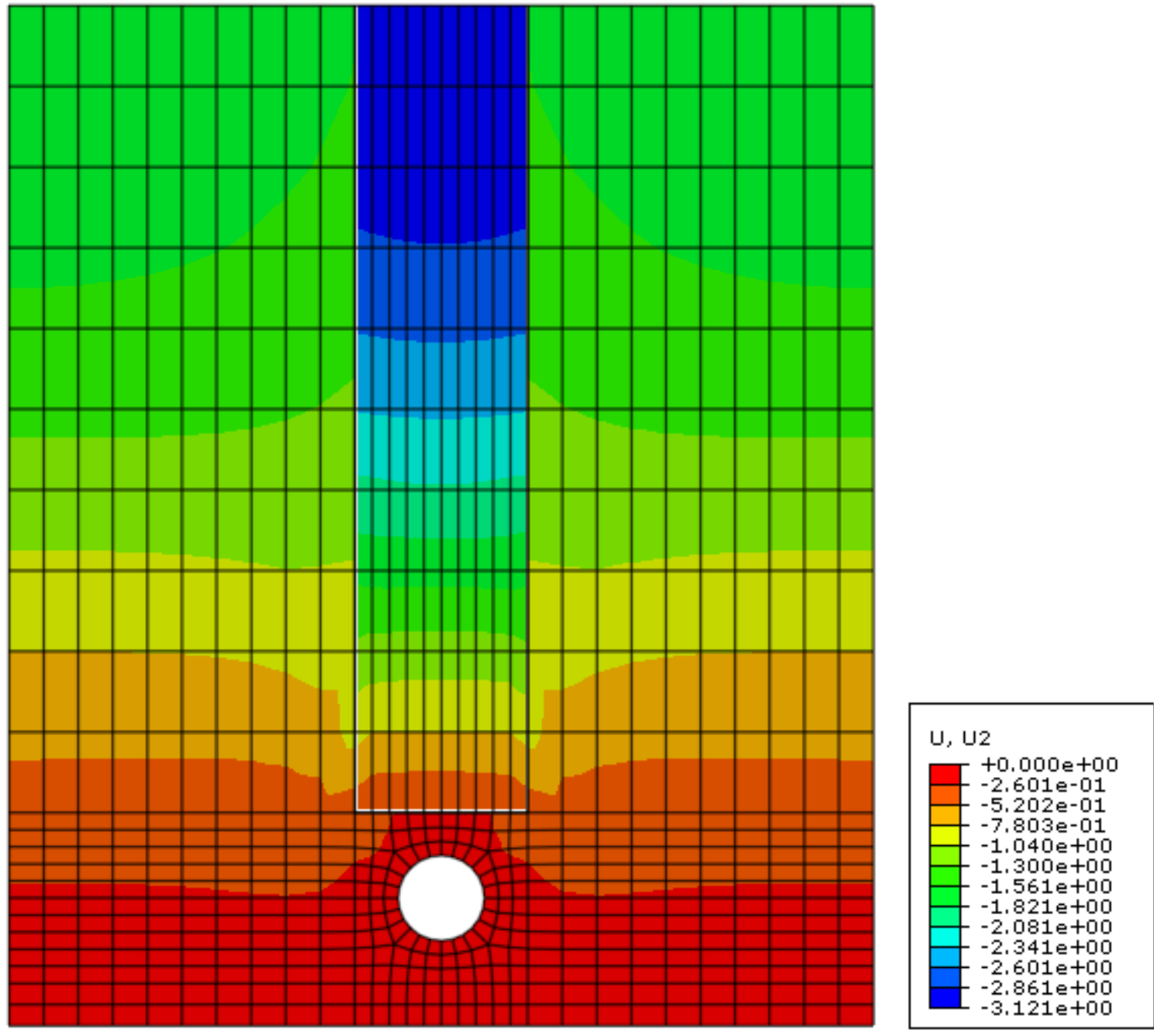

Note: Displacements are given in inches

Figure 6.14: Displacements of a 24-inch PVC pipe buried in granular material under 20 feet of trench backfill and at a trench width ratio of 2.0 


\subsubsection{Embankment Loading}

Embankment loading was considered for pipes buried at trench backfill heights of 30 feet and 50 feet. Figure 6.15 shows the 50 year deformation of a 24 -inch diameter PVC pipe for soil influenced by the self-weight of soil at a trench-width ratio of 2.0 and a backfill height of 50 feet with granular stone backfill material.

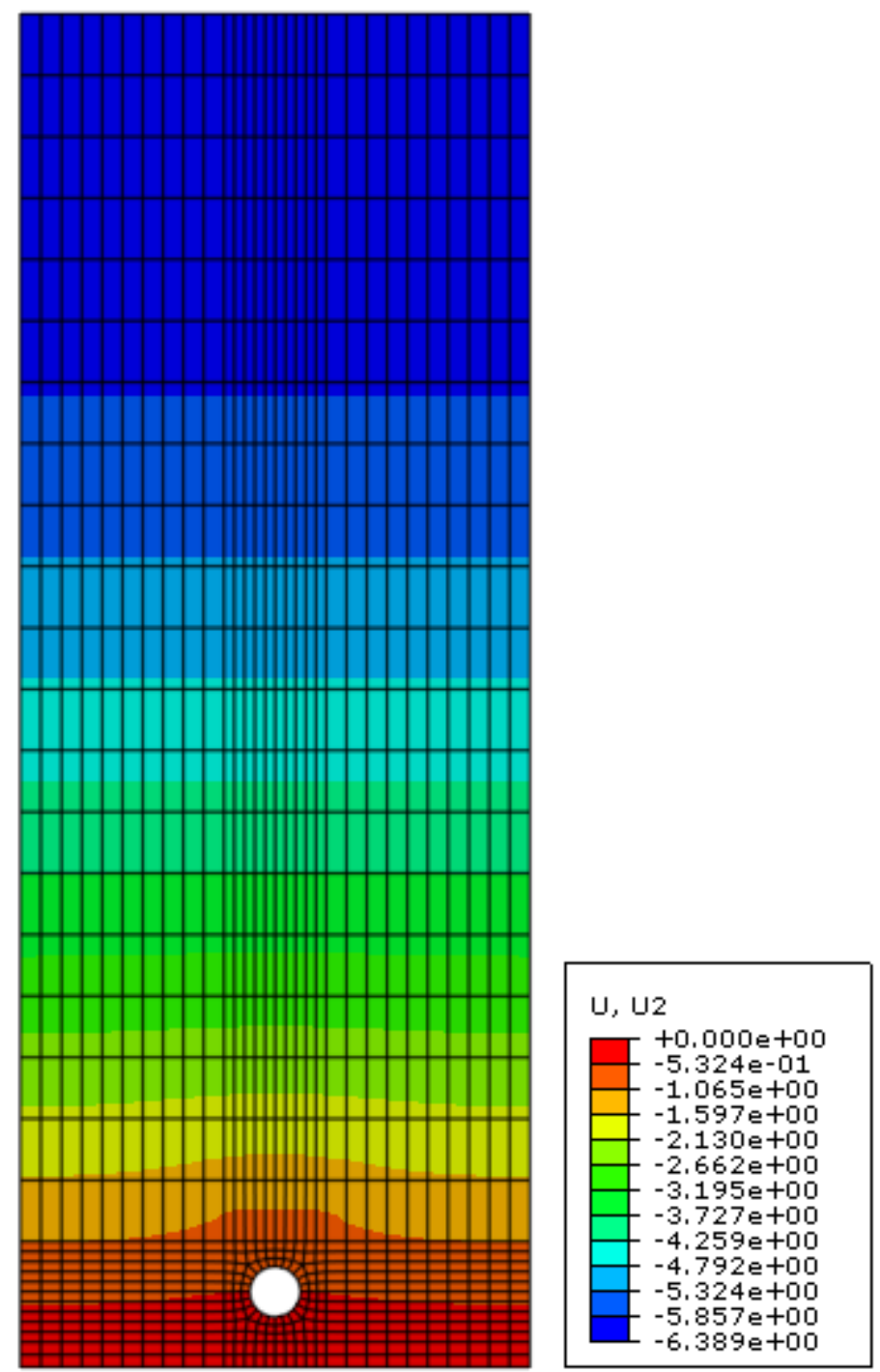

Note: Displacements are given in inches

Figure 6.15: Displacements of a 24-inch PVC pipe buried in granular material under 50 feet of trench backfill and a TW ratio of 2.0 


\subsubsection{Influence of Pipe Backfill Material}

A comparison of displacements for a 24-inch diameter PVC pipe with a trench-width ratio of 2.0 under different backfill materials and backfill heights are presented. Figure 6.16 compares the deflection of HDPE pipe buried in different pipe backfill materials: granular and clay backfill material. As can be seen from this figure, pipes in clay material deflect more than pipes in granular stone backfill material. Figures 6.17 and 6.18 compare the pipe deflections of a PVC pipe installed under increasing backfill heights. As the backfill height increases, the deflection of the pipe also increases.

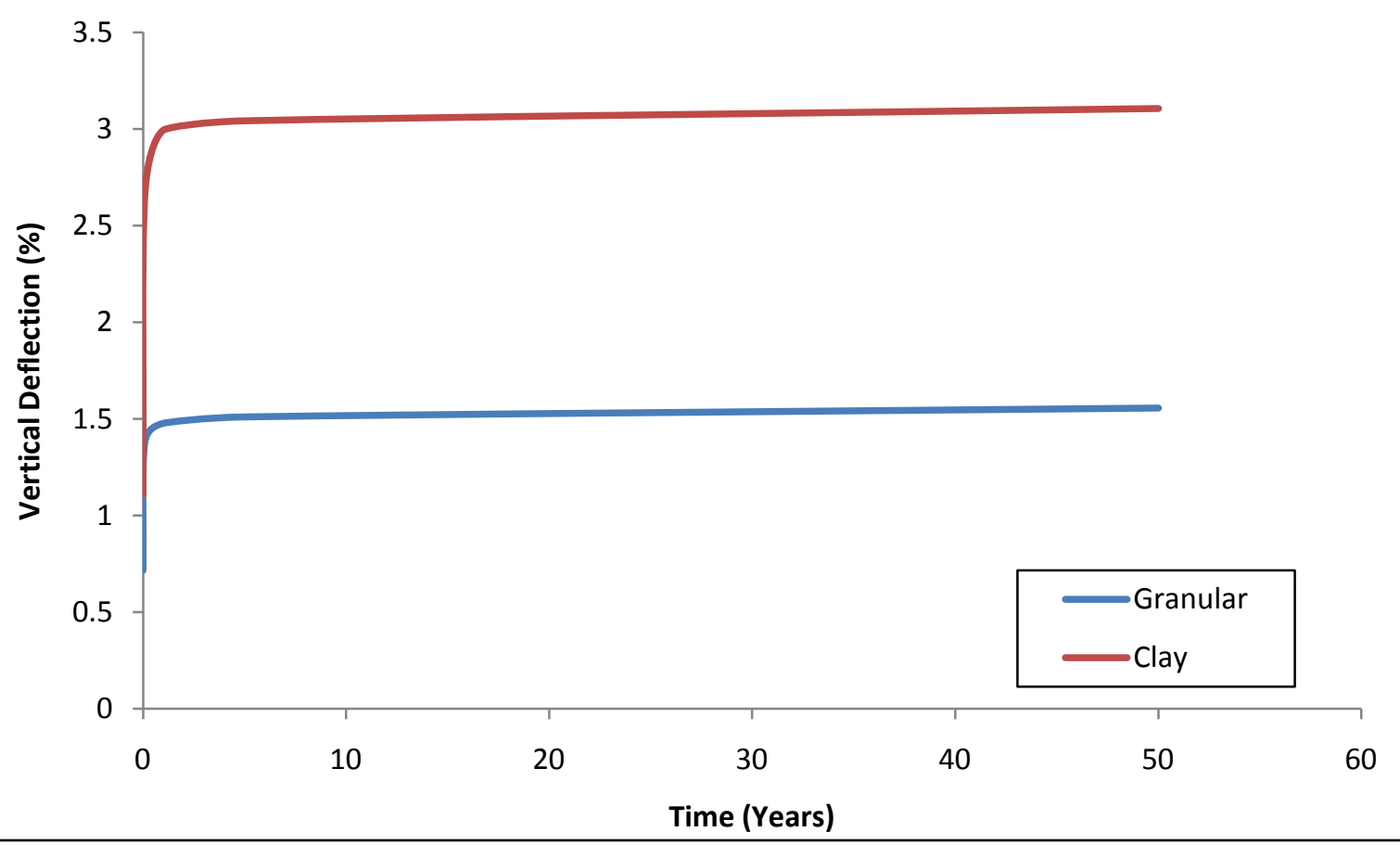

Figure 6.16: Vertical pipe deflection for a 24-inch PVC pipe installed at a depth of 50 feet 


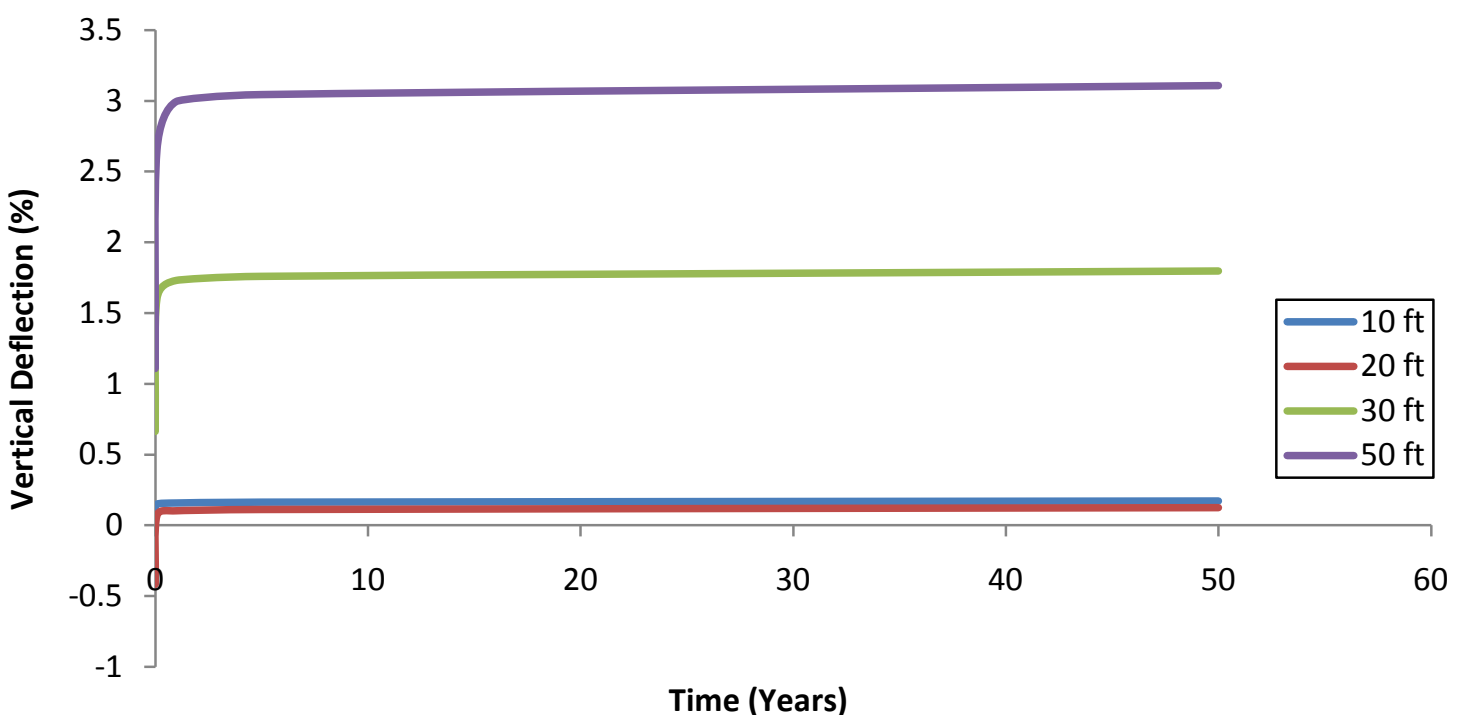

Figure 6.17: Pipe deflections for a 24-inch PVC pipe with clay backfill material

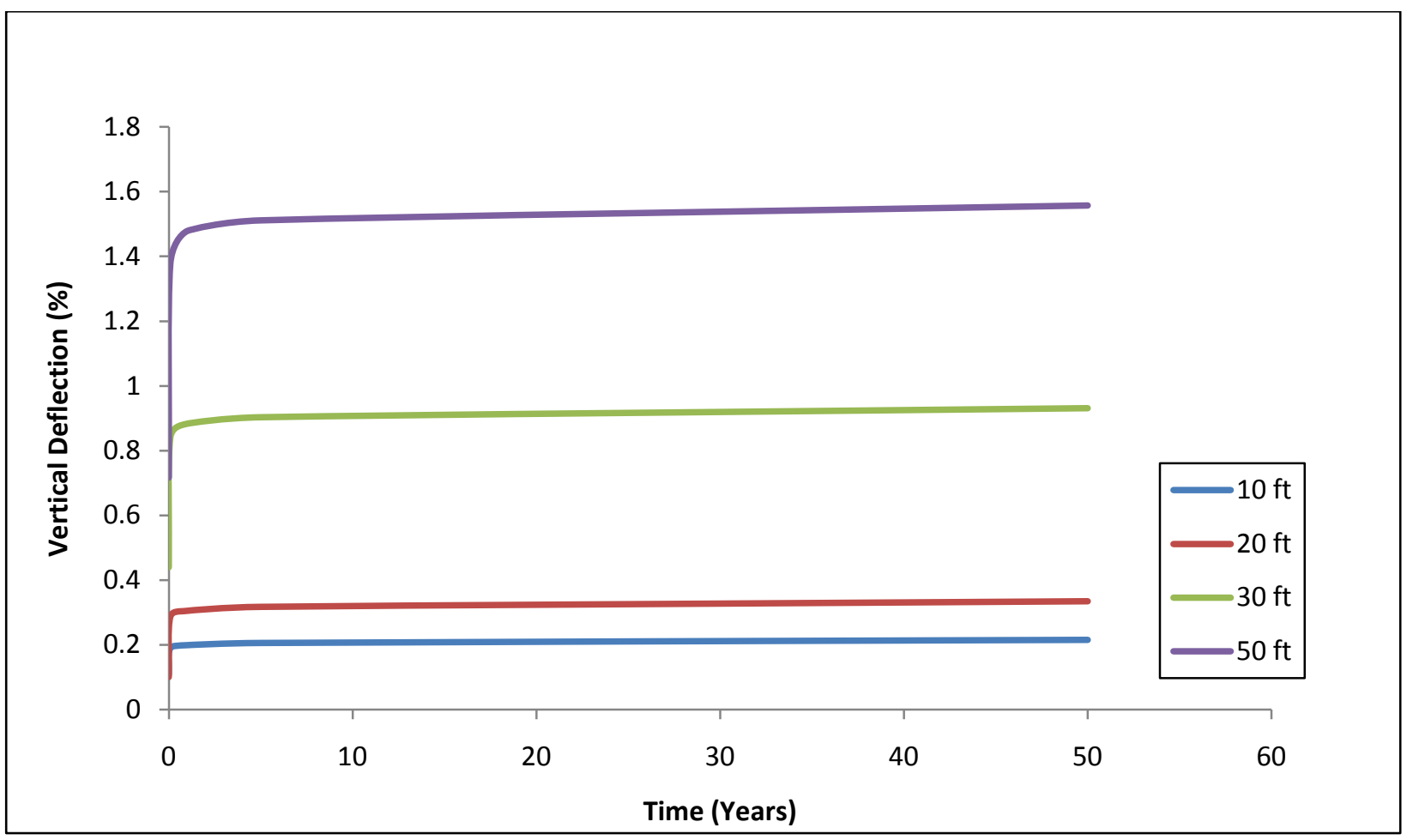

Figure 6.18: Pipe deflections for a 24-inch PVC pipe with granular stone backfill 


\subsubsection{Influence of Trench-width Ratio}

Figures 6.19 and 6.20 compare the vertical deflection of the 24-inch PVC pipe under increasing backfill heights, as well as trench-width ratios of 1.5, 2.0, and 2.5. There is not a significant difference of pipe deflections based upon the trench-width ratio when the pipe is in clay backfill material. For the PVC pipe buried in granular material, it can be noted that a greater trench-width ratio gives a lesser deflection. These results indicate that smaller trenchwidth ratios may be used without causing significant increase in pipe deflections. However, the influence of trench-width ratio on pipe deflections depends on pipe diameter and the backfill material.

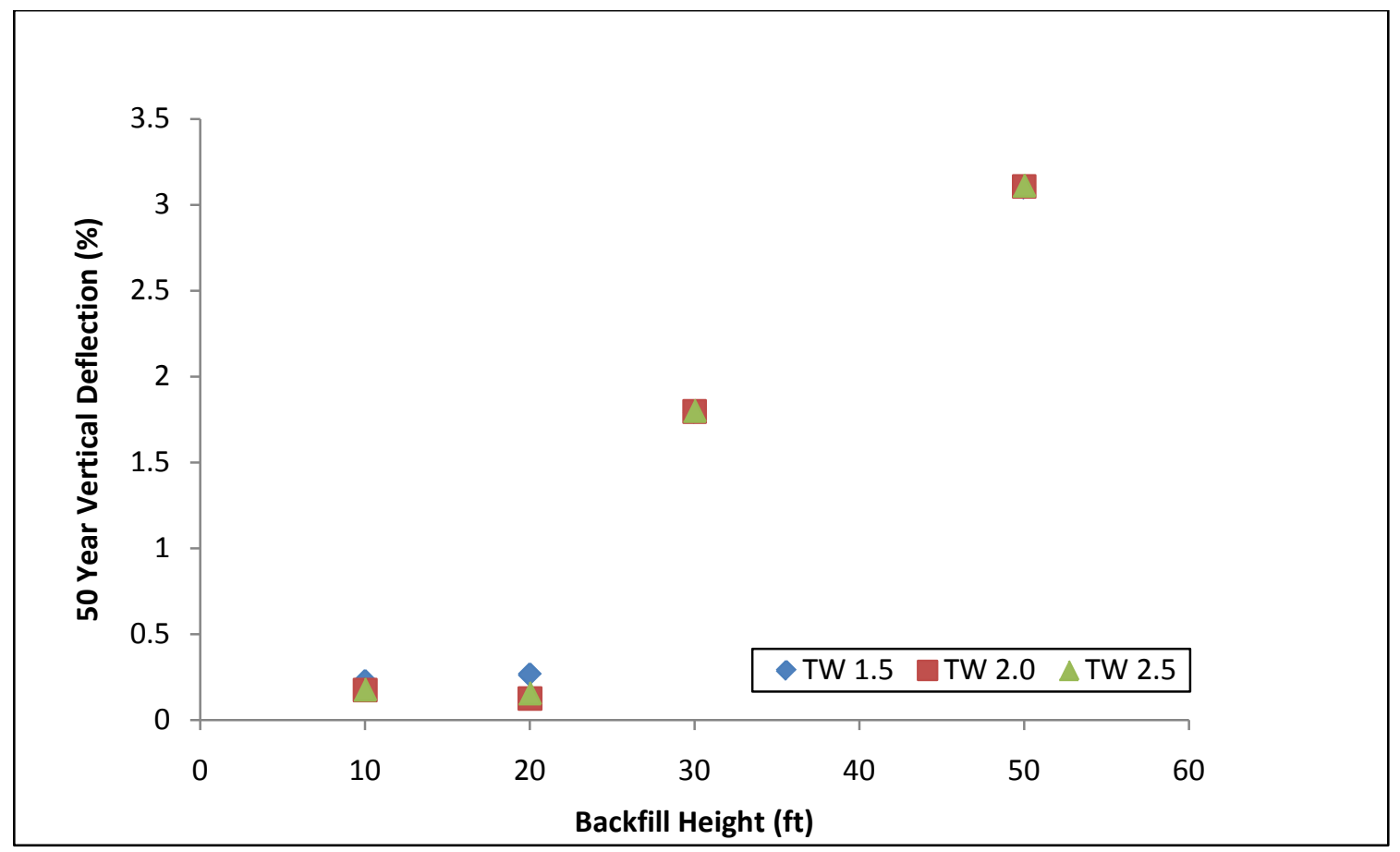

Figure 6.19: Effect of trench-width ratio for a 24-inch PVC pipe with clay backfill 


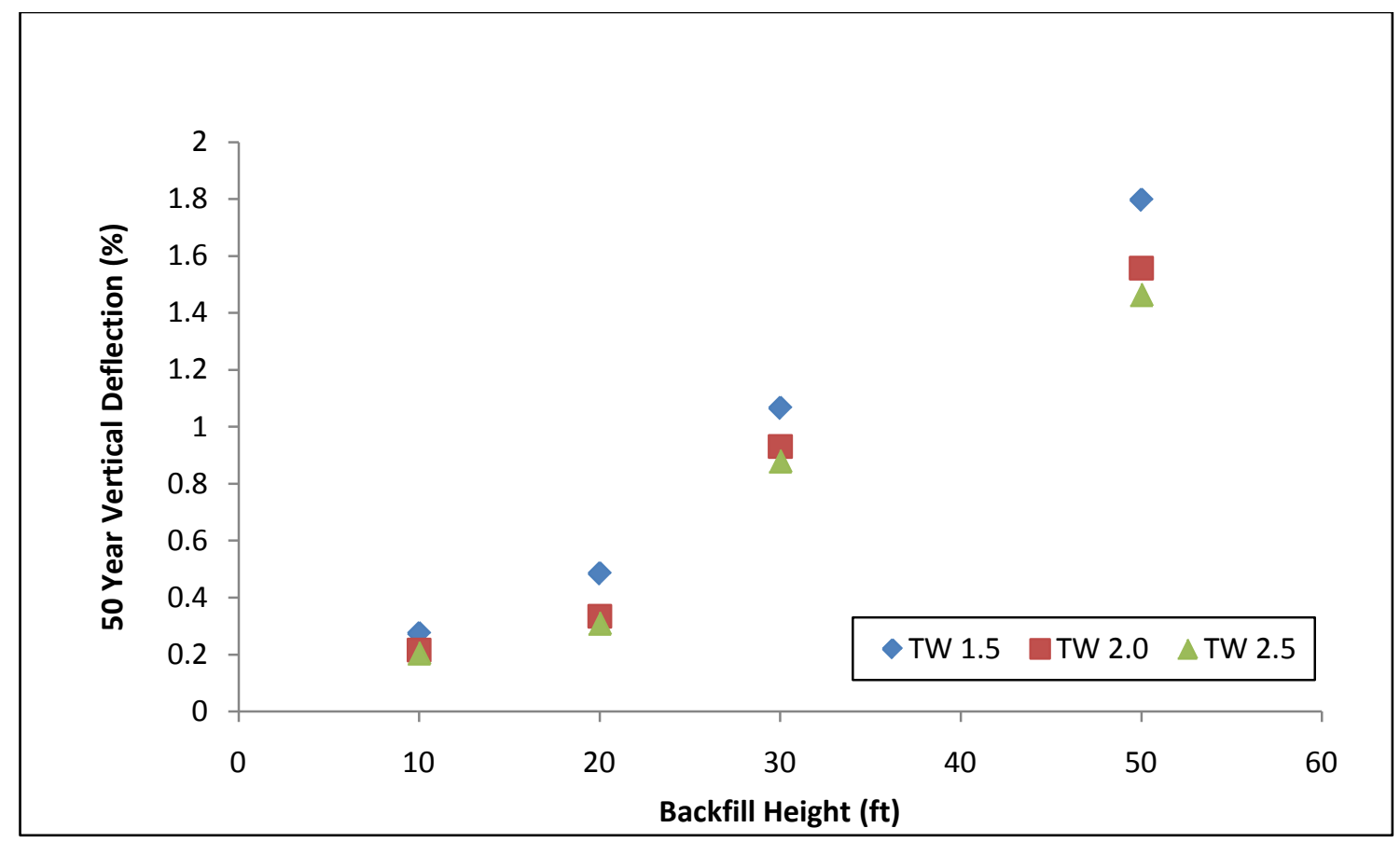

Figure 6.20: Effect of trench-width ratio for a 24-inch PVC pipe with granular backfill

\subsubsection{Influence of Pipe Diameter}

In order to investigate the influence of pipe diameter, a trench width ratio of 2.0 was selected. Figures 6.21 and 6.22 compare the deflection of various PVC pipe diameters installed at different depths. As expected, the numerical models show that larger diameter pipes deflect more than the smaller diameter pipes. Also, as the backfill height increases, the pipe deflection increases. The pipe deflection did not reach 5\% in any of the cases shown in these figures, which is considered as the failure criterion. These results show that a 24-inch PVC pipe can be buried to depths as high as 50 feet without causing significant pipe deflections. 


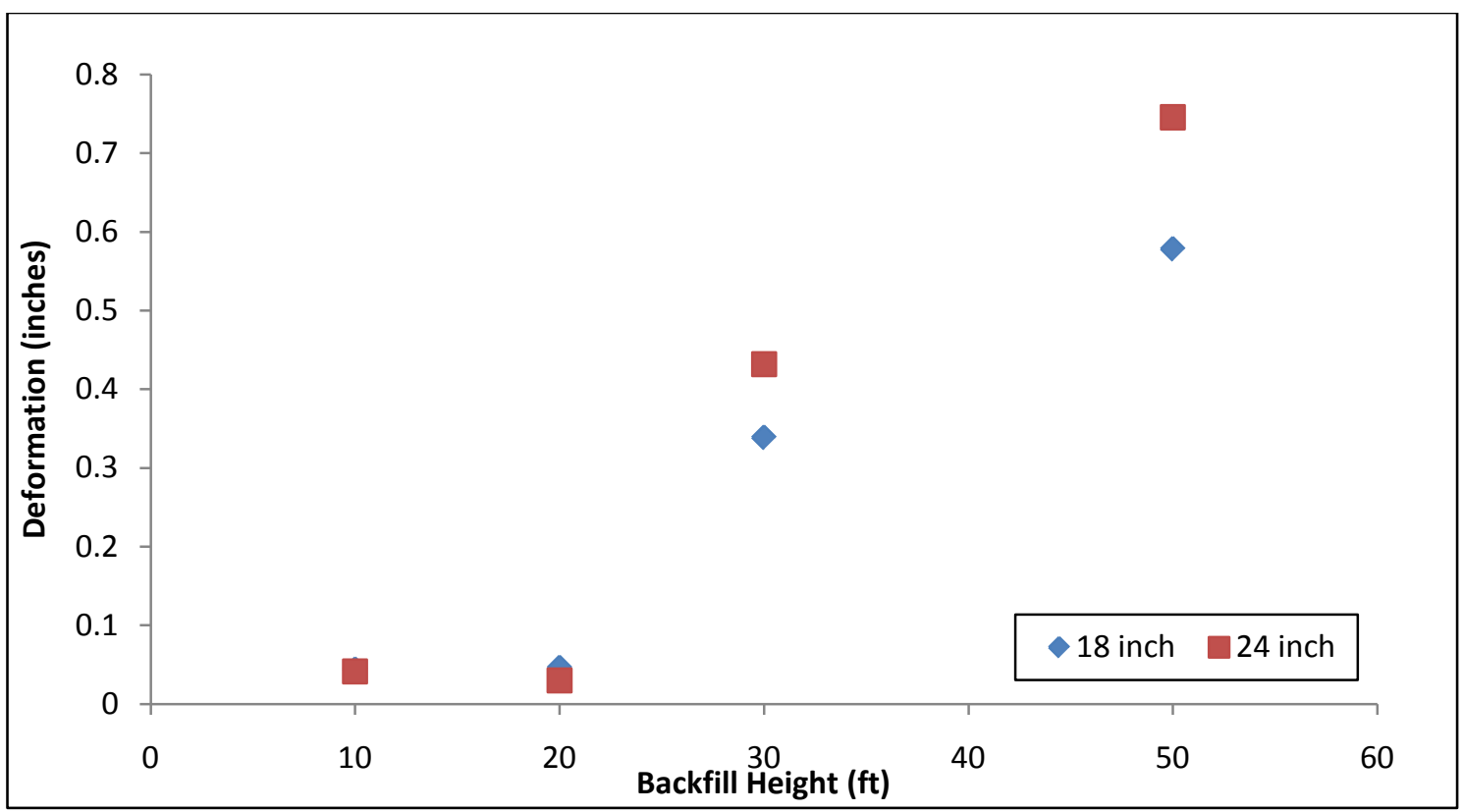

Figure 6.21: Deflection of various PVC pipe diameters with clay backfill material

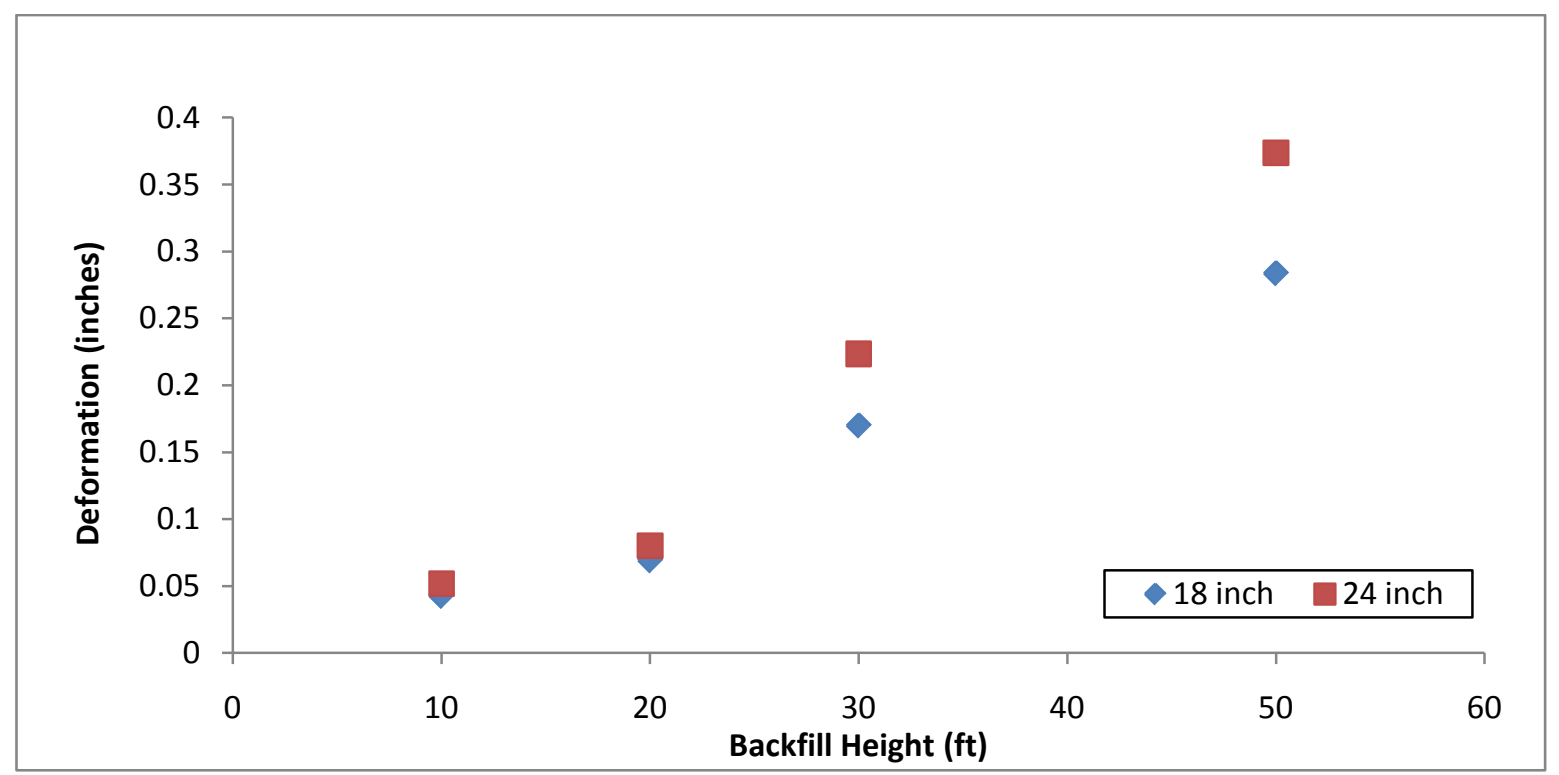

Figure 6.22: Deflection of various PVC pipe diameters with granular stone backfill

\subsection{Creep Response of PVC Pipes}

The creep response of a 24-inch solid-wall PVC pipe buried under different trench-width ratios, trench backfill heights, and pipe backfill material (granular and clay) is presented in this 
section. Only a limited number of cases were completed for the creep study since the objective of this study was to investigate the combined influence of creep and consolidation. Results for all of the cases investigated are presented in Appendix A, and a summary is presented below.

A comparison of creep displacements for a 24-inch diameter PVC pipe with a trenchwidth ratio of 2.0 under different backfill materials and backfill heights are presented for a 50year period in Figures 6.23 to 6.25. Figure 6.23 compares the deflection of PVC pipe buried in different pipe backfill materials: granular and clay backfill material. As can be seen from this figure, pipes buried in clay material deflect more than pipes buried in granular material. Figures 6.24 and 6.25 compare the pipe deflections of a PVC pipe installed under increasing backfill heights. As the backfill height increases, the deflection of the pipe also increases. These figures show that the pipe deflections are smaller than 5\% during the 50-year period.

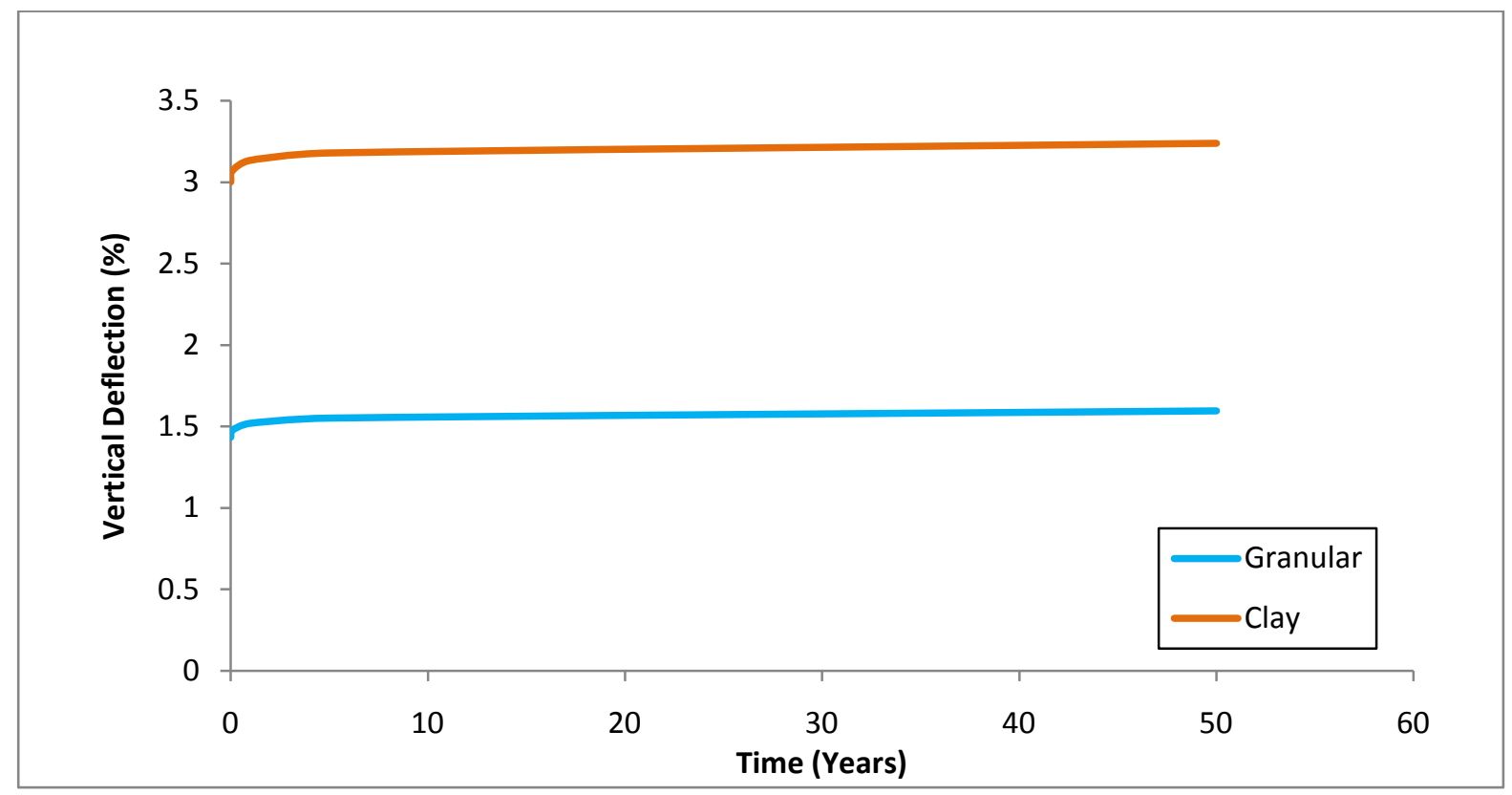

Figure 6.23: Vertical pipe deflection for a 24-inch PVC pipe installed at a depth of 50 feet 


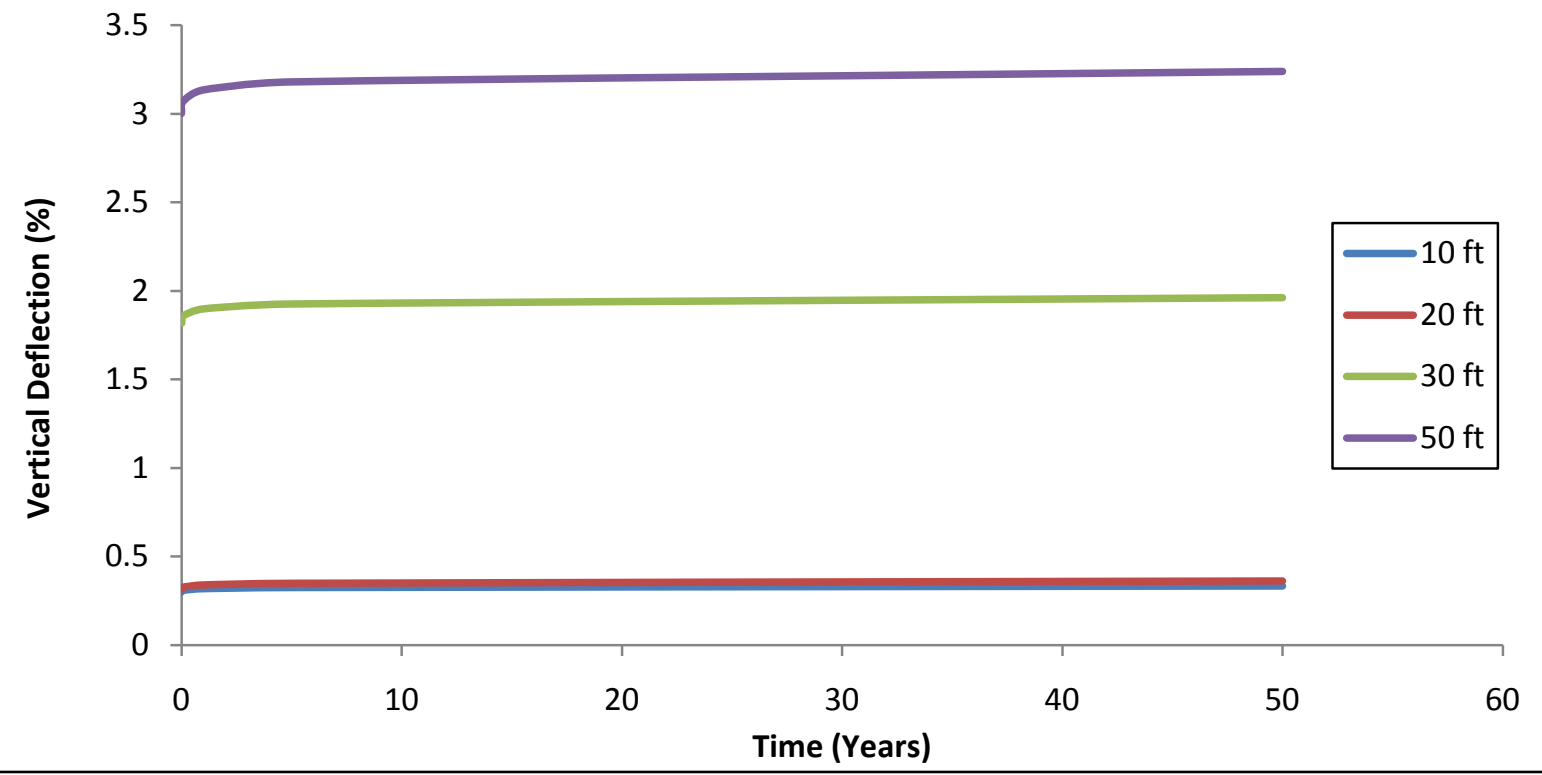

Figure 6.24: Pipe deflections for a 24-inch PVC pipe with clay backfill material

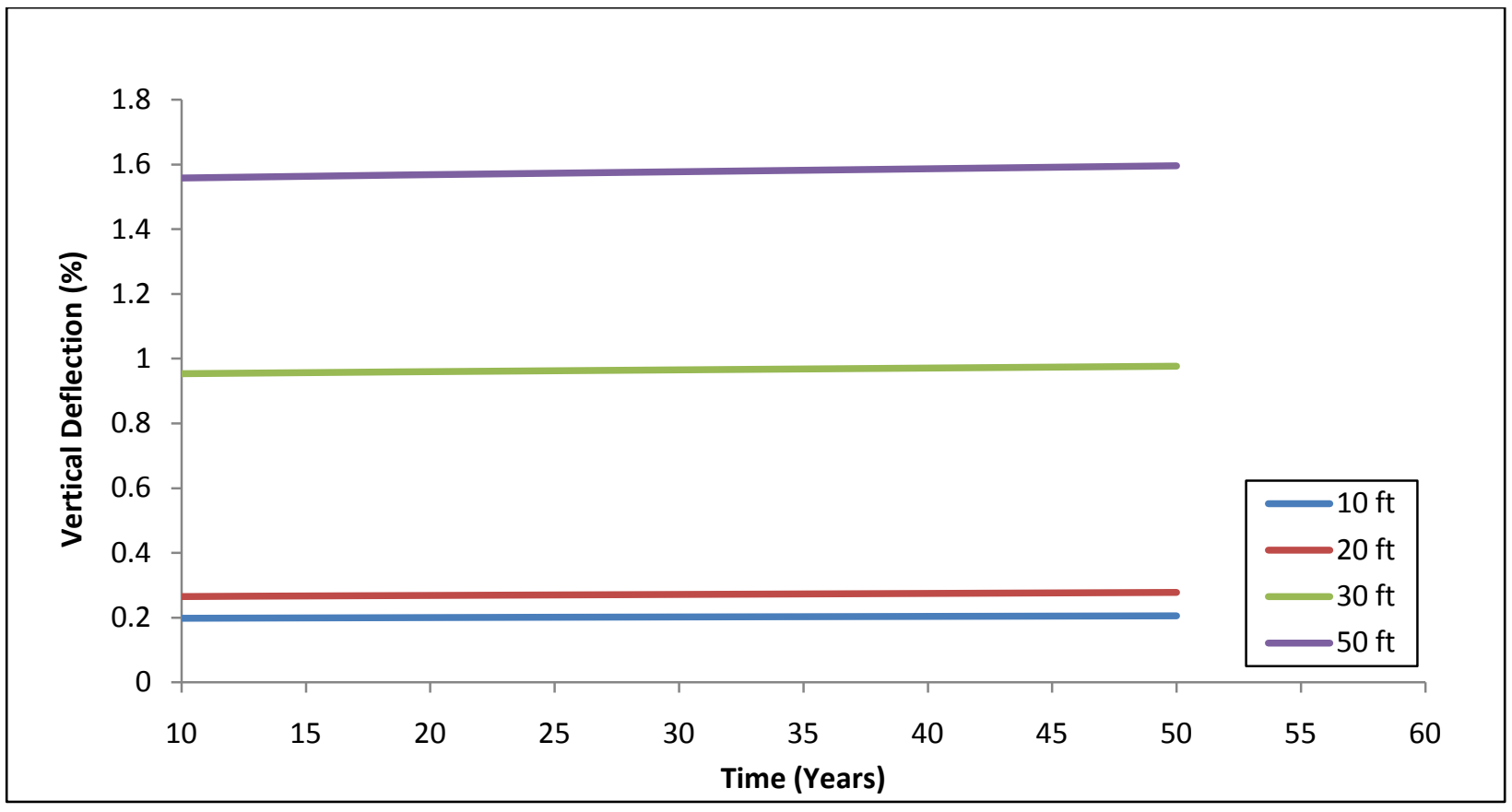

Figure 6.25: Pipe deflections for a 24-inch PVC pipe with granular stone backfill 


\subsection{Combined Influence of Creep and Consolidation}

Figure 6.26 compares the vertical deflection of a 24-inch PVC pipe under different conditions: (a) only creep of the pipe material and (b) the combined influence of creep and soil consolidation. Buried pipes influenced by both time-dependent properties of creep and soil consolidation have a slightly lesser deflection than those only influenced by creep. This could be due to the fact that the soil weight acts instantaneously on the pipe when there is no consolidation, which in turn gives rise to higher creep rates at the beginning.

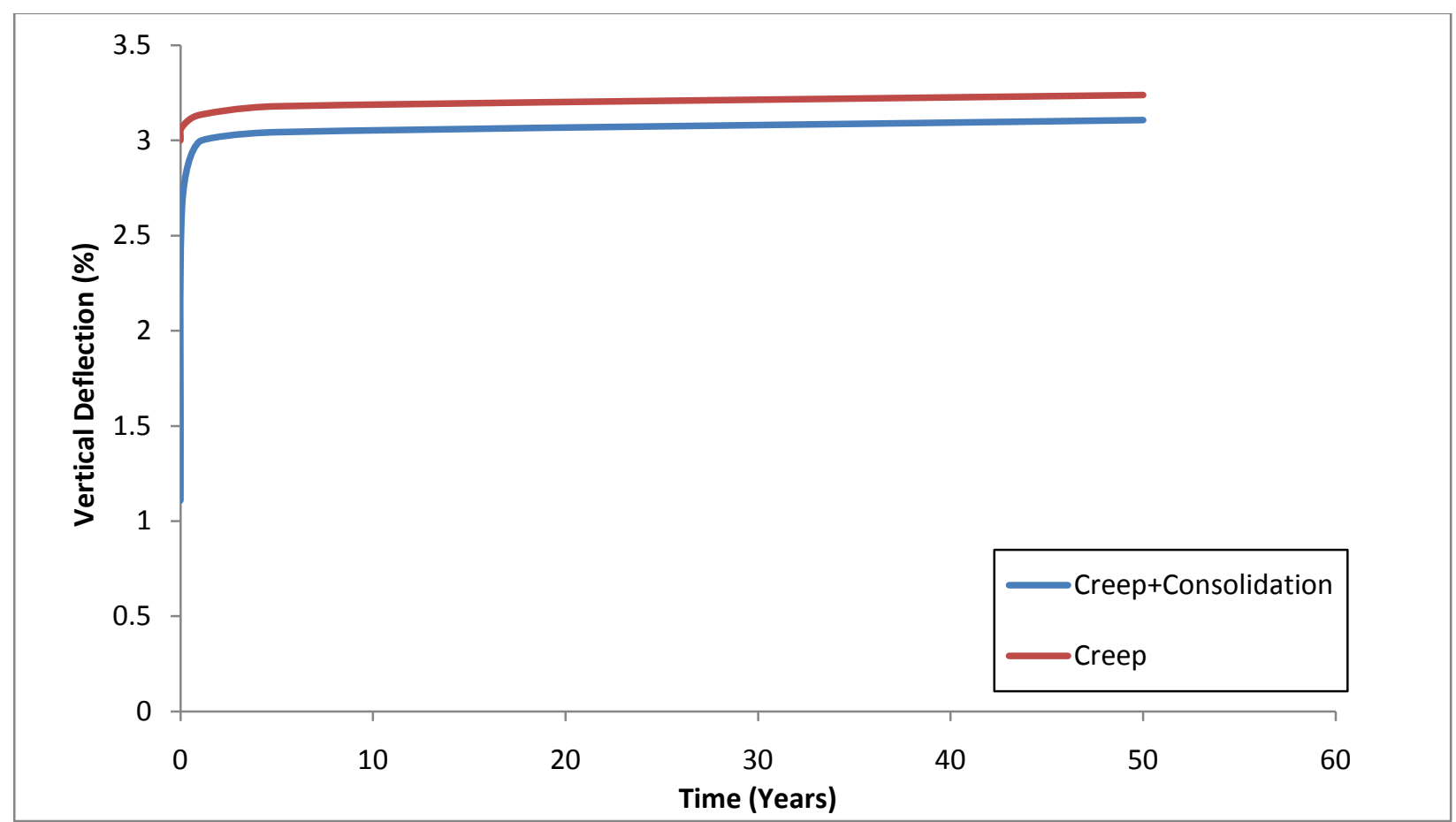

Figure 6.26: Comparison of pipe deflection for 24-inch PVC pipe under 50 feet of backfill in a trench-width of 2.0 with clay backfill 


\subsection{Summary of Results for PVC Pipes}

Analyses of cases shown in Table 6.7 and Table 6.8 were completed in a manner similar to what was presented in the previous section. Table 6.9 shows the pipe deflections for PVC pipes with clay backfill under the combined influence of creep and consolidation. Table 6.10 shows pipe deflections for the same cases as a percentage of pipe diameters. As can be seen from these tables, none of the pipes reach 5\% pipe deflection under the combined influence of creep and consolidation. As can be seen from these tables, even for the cases corresponding to trenchwidth ratio of 1.5 , the pipes did not reach $5 \%$ deflections under the self-weight of soil. These results suggest the possibility of using smaller trench-width ratios. However, the influence of trench-width ratio on pipe deflections depends on pipe diameter and the backfill material.

Table 6.9: Deflection of PVC pipe (inches)

\begin{tabular}{|c|c|c|c|c|c|c|}
\hline \multicolumn{2}{|c|}{ PVC Creep+ Consolidation Analyses: Clay Pipe Backfill } \\
\hline \multicolumn{2}{|c|}{ Diameter: 18-inch } & \multicolumn{3}{c|}{ Diameter: 24-inch } \\
\hline $\begin{array}{c}\text { Trench- } \\
\text { Width Ratio }\end{array}$ & 1.5 & 2.0 & 2.5 & 1.5 & 2.0 & 2.5 \\
\hline $\begin{array}{c}\text { Depth: } 10 \\
\text { feet }\end{array}$ & 0.057 & 0.044 & 0.040 & 0.054 & 0.042 & 0.042 \\
\hline $\begin{array}{c}\text { Depth: } 20 \\
\text { feet }\end{array}$ & 0.084 & 0.046 & 0.036 & 0.064 & 0.030 & 0.037 \\
\hline $\begin{array}{c}\text { Depth: } 30 \\
\text { feet }\end{array}$ & 0.338 & 0.338 & 0.339 & 0.0430 & 0.431 & 0.432 \\
\hline $\begin{array}{c}\text { Depth: } 50 \\
\text { feet }\end{array}$ & 0.576 & 0.578 & 0.578 & 0.744 & 0.746 & 0.747 \\
\hline
\end{tabular}


Table 6.10: Deflection of PVC pipe (percentage)

\begin{tabular}{|c|c|c|c|c|c|c|}
\hline \multicolumn{2}{|c|}{ PVC Creep + Consolidation Analyses: Clay Pipe Backfill } \\
\hline \multicolumn{2}{|c|}{ Diameter: 18-inch } & \multicolumn{3}{c|}{ Diameter: 24-inch } \\
\hline $\begin{array}{c}\text { Trench- } \\
\text { Width Ratio }\end{array}$ & 1.5 & 2.0 & 2.5 & 1.5 & 2.0 & 2.5 \\
\hline $\begin{array}{c}\text { Depth: } 10 \\
\text { feet }\end{array}$ & 0.317 & 0.244 & 0.222 & 0.225 & 0.175 & 0.175 \\
\hline $\begin{array}{c}\text { Depth: } 20 \\
\text { feet }\end{array}$ & 0.467 & 0.256 & 0.200 & 0.267 & 0.125 & 0.154 \\
\hline $\begin{array}{c}\text { Depth: } 30 \\
\text { feet }\end{array}$ & 1.878 & 1.878 & 1.883 & 0.179 & 1.796 & 1.800 \\
\hline $\begin{array}{c}\text { Depth: } 50 \\
\text { feet }\end{array}$ & 3.200 & 3.211 & 3.211 & 3.100 & 3.108 & 3.113 \\
\hline
\end{tabular}

Table 6.11 shows the pipe deflections for PVC pipes with granular stone backfill under the combined influence of creep and consolidation. Table 6.12 shows pipe deflections for the same cases as a percentage of pipe diameters. As can be seen from these tables, none of the pipes with granular stone backfill reach 5\% pipe deflection under the combined influence of creep and consolidation. The conclusions that can be drawn from the results for granular backfill materials are similar to those for clay backfill materials, and none of the pipes reach $5 \%$ pipe deflections under the self-weight of soil. 
Table 6.11: Deflection of PVC pipes (inches)

\begin{tabular}{|c|c|c|c|c|c|c|}
\hline \multicolumn{2}{|c|}{ PVC Creep + Consolidation Analyses: Granular Pipe Backfill } \\
\hline \multicolumn{2}{|c|}{ Diameter: 18-inch } & \multicolumn{3}{|c|}{ Diameter: 24-inch } \\
\hline $\begin{array}{c}\text { Trench- } \\
\text { Width } \\
\text { Ratio }\end{array}$ & 1.5 & 2.0 & 2.5 & 1.5 & 2.0 & 2.5 \\
\hline $\begin{array}{c}\text { Depth: } 10 \\
\text { feet }\end{array}$ & 0.056 & 0.042 & 0.037 & 0.066 & 0.052 & 0.049 \\
\hline $\begin{array}{c}\text { Depth: } 20 \\
\text { feet }\end{array}$ & 0.105 & 0.069 & 0.056 & 0.116 & 0.080 & 0.074 \\
\hline $\begin{array}{c}\text { Depth: } 30 \\
\text { feet }\end{array}$ & 0.200 & 0.170 & 0.157 & 0.256 & 0.223 & 0.211 \\
\hline $\begin{array}{c}\text { Depth: } 50 \\
\text { feet }\end{array}$ & 0.334 & 0.284 & 0.260 & 0.431 & 0.374 & 0.351 \\
\hline
\end{tabular}


Table 6.12: Deflection of PVC pipe (percentage)

\begin{tabular}{|c|c|c|c|c|c|c|}
\hline \multicolumn{2}{|c|}{ PVC Creep + Consolidation Analyses: Granular Pipe Backfill } \\
\hline \multicolumn{2}{|c|}{ Diameter: 18-inch } & \multicolumn{3}{|c|}{ Diameter: 24-inch } \\
\hline $\begin{array}{c}\text { Trench- } \\
\text { Width } \\
\text { Ratio }\end{array}$ & 1.5 & 2.0 & 2.5 & 1.5 & 2.0 & 2.5 \\
\hline $\begin{array}{c}\text { Depth: } 10 \\
\text { feet }\end{array}$ & 0.311 & 0.233 & 0.206 & 0.275 & 0.217 & 0.204 \\
\hline $\begin{array}{c}\text { Depth: } 20 \\
\text { feet }\end{array}$ & 0.583 & 0.383 & 0.311 & 0.483 & 0.333 & 0.308 \\
\hline $\begin{array}{c}\text { Depth: } 30 \\
\text { feet }\end{array}$ & 1.111 & 0.944 & 0.872 & 1.067 & 0.929 & 0.879 \\
\hline $\begin{array}{c}\text { Depth: } 50 \\
\text { feet }\end{array}$ & 1.856 & 1.578 & 1.444 & 1.796 & 1.558 & 1.463 \\
\hline
\end{tabular}

\subsection{Comparison of HPDE and PVC Pipe Materials}

This research study compared the vertical deflections of both HDPE and PVC pipe materials. The vertical deflections of 24-inch HDPE and PVC pipes buried under 20 feet of trench backfill, and under the influence of both creep and soil consolidation, are compared in Figure 6.27. In Figure 6.28, the deflections of both pipe materials buried under 50 feet of trench backfill are compared. 


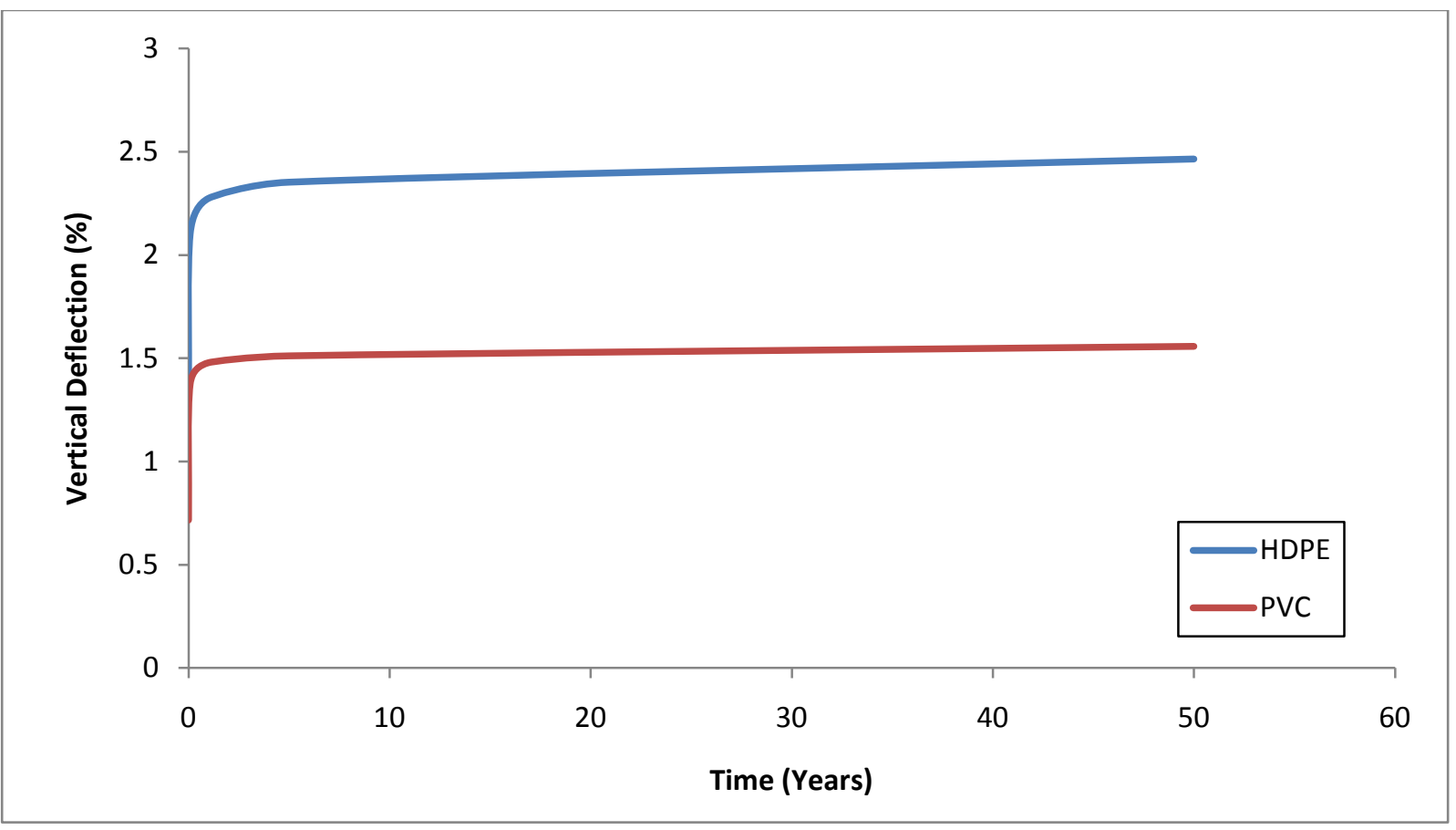

Figure 6.27: Comparison of both pipe materials: 24-inch diameter with granular backfill under a trench backfill height of 50 feet and with a trench-width ratio of 2.0

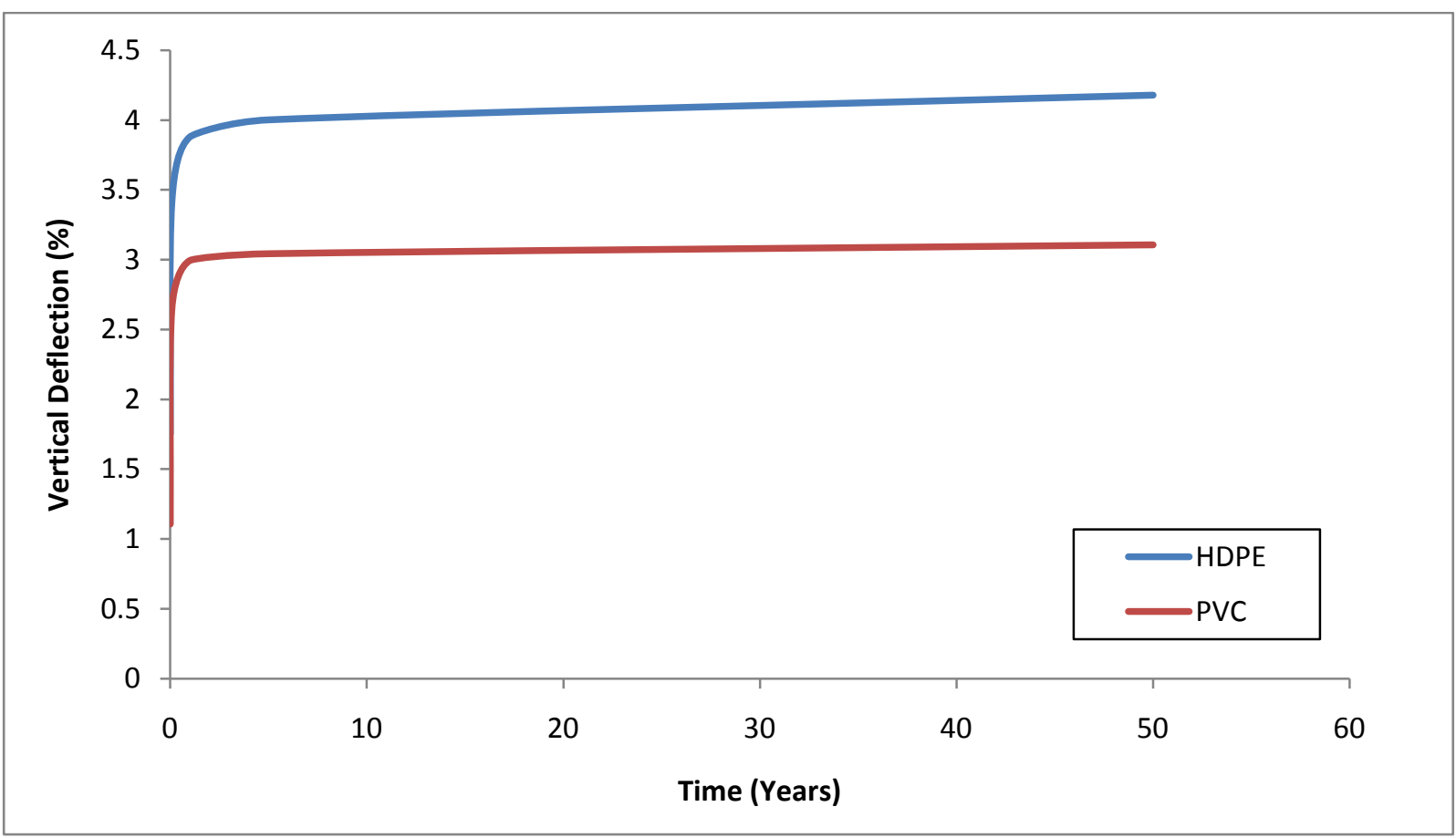

Figure 6.28: Comparison of both pipe materials: 24-inch diameter with clay backfill under a trench backfill height of 50 feet and with a trench-width ratio of 2.0 


\subsection{Influence of Drainage Conditions}

In this study, two drainage boundary conditions were used: one at the ground surface, and the other at the pipe/soil interface. In order to investigate the influence of draining conditions on pipe deflections, the soil/pipe interface drainage condition was suppressed and the deflection of the pipe was computed. The deflection of a 60-inch diameter HDPE pipe buried at a depth of 50 feet and a trench-width ratio of 2.0 was selected for this study, and the results are shown in Figure 6.29. As can be seen from this figure, the worst-case scenario happens when both drainage boundary conditions are invoked.

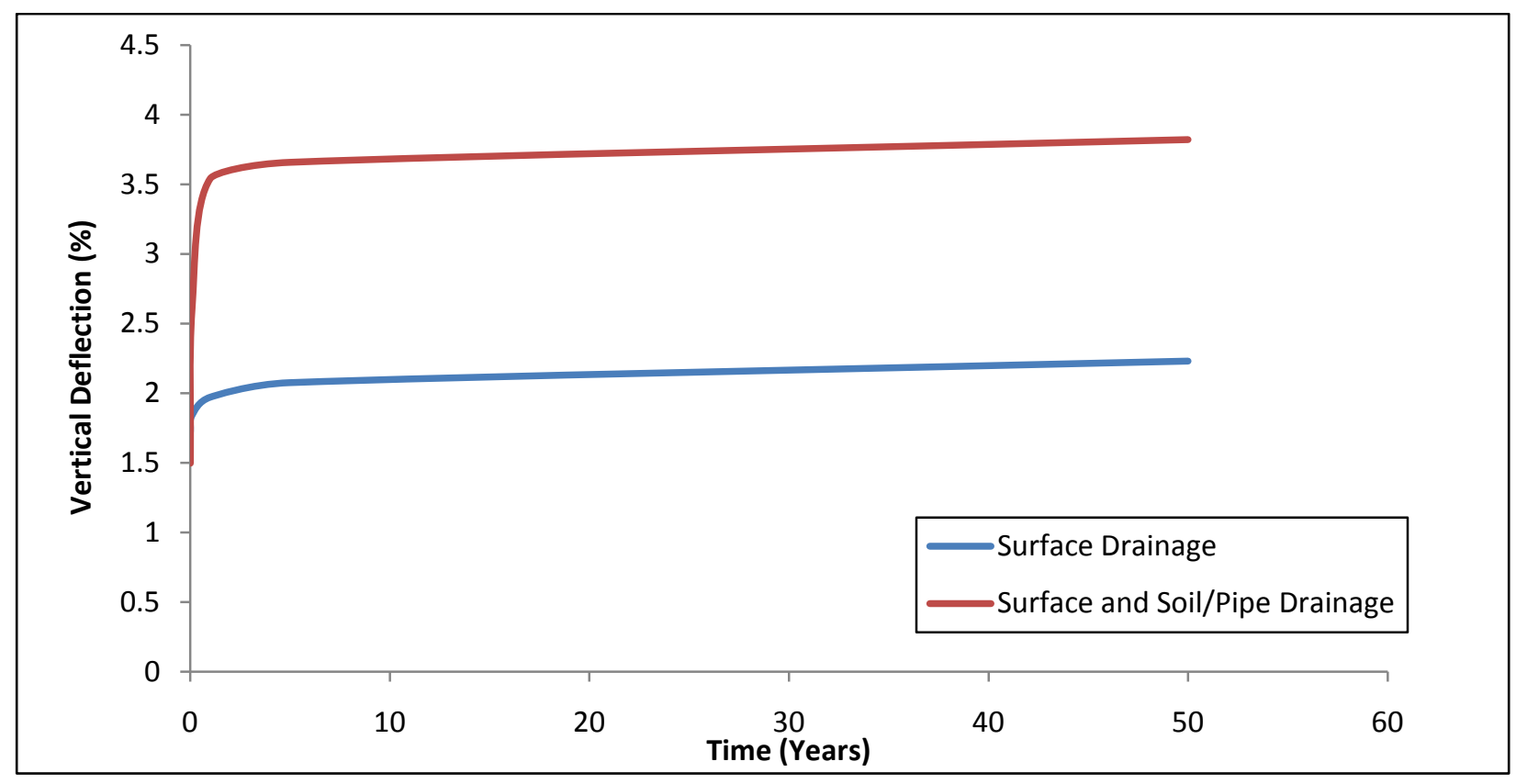

Figure 6.29: Comparison of drainage boundary conditions 


\section{CHAPTER 7: SUMMARY AND CONCLUSIONS}

\subsection{Summary}

The objective of this research work was to investigate the time-dependent performance of buried pipes in a consolidating soil medium. Two types of analyses were performed: buried pipes influenced by both creep and soil consolidation, and buried pipes only influenced by creep. The deflections of these pipes were compared to one another. Granular stone material and clay material were the two types of pipe backfill material considered in this study. Different drainage conditions were simulated, as well as different external soil loadings, dependent on the depth of burial of the pipe. Various pipe diameters and trench-width ratios were also considered. The soil-pipe system was a very important aspect of this research study due to the interface and the process of soil consolidation around the pipe.

For this study, solid-wall polyvinyl chloride (PVC) pipes with diameters ranging from 18-inches to 24-inches and double-wall corrugated high-density polyethylene (HDPE) pipes with diameters ranging from 24-inches to 60-inches were selected. Trench backfill heights of 10 feet, 20 feet, 30 feet, and 50 feet were considered, as well as trench-width ratios of 1.5, 2.0, and 2.5. A gravity loading was placed throughout the soil to act as the self-weight of the soil. This was the only load acting on the pipe.

\subsection{Conclusions}

The following conclusions were made based upon the results of the research work:

- As the trench backfill height increases, the pipe deflections increase.

- $\quad$ Pipes with clay backfill materials deflect more than the pipes with granular stone backfill material.

- The creep analysis (without consolidation) gives slightly higher displacements than the creep and soil consolidation analysis since the load on the pipe is applied instantaneously. On average, about $80 \%$ of the pipe deflection occurs within the first day with only creep 
being the time-dependent property acting on the pipe. In the consolidation analysis, the load on the pipe changes as the pore pressure dissipates as a function of time. About $20 \%$ to $50 \%$ of the pipe deflection occurs within the first day.

- A trench-width ratio of 1.5 causes the pipe to have a slightly higher deformation than the trench-width ratios of 2.0 and 2.5. However, for some of the analyses (mainly pipes in clay pipe backfill material), the trench-width ratio does not cause a significant change in pipe deflection.

- HDPE pipes deflect more than pipes made of PVC due to the material modulus.

- Buried pipes have a higher deflection when surface and soil/pipe interface drainage occurs than when surface drainage is the only drainage boundary considered.

\subsection{Future Recommendations}

- Consider a soil model with changing permeability values and void ratios as the consolidation process occurs.

- Consider controlled low strength material (CLSM) for the pipe backfill.

- Perform the same study but consider rigid pipes; the soil-arching phenomenon may play an important role in the deflections of the pipes.

- Consider different types of HDPE and PVC pipes, i.e. corrugated PVC pipes, single-wall corrugated HDPE pipes.

- Study the effects of placing a geosynthetic above the conduit.

- Allow the soil to be partially saturated instead of assuming $100 \%$ saturation. 


\section{REFERENCES}

AASHTO M 294 (2007) Standard Specification for Corrugated Polyethylene Pipe, 300- to 1500mm Diameter. American Association of State Highway and Transportation Officials.

AASHTO M294 (2002) Standard specification for corrugated polyethylene pipe. American Association of State Highway and Transportation Officials.

ADS, Inc. Advanced Drainage Systems: Technical notes [Online]. (2006) Available: http://www.ads-pipe.com

Arvidsson, J. and Gronavall, J. (2004) Analysis of creep in paperboard packages with plastic tops. M.S. Thesis, Division of Structural Mechanics, LTH, Lund University, Sweden, August.

ASTM D2412 (2000) Standard Test Method for Determination of External Loading Characteristics of Plastic Pipe by Parallel-Plate Loading. American Standard for Testing Materials.

ASTM D3034 (2006) Standard Specification for Type PSM Poly (Vinyl Chloride) (PVC) Sewer Pipe and Fittings. American Standard for Testing Materials.

ASTM F679 (2006) Standard Specification for Poly (Vinyl Chloride) (PVC) Large-Diameter Plastic Gravity Sewer Pipe and Fittings. American Standard for Testing Materials.

Booker, J. R. and J.C. Small. (1977) Finite Element Analysis of Primary and Secondary Consolidation. International Journal of Solids and Structures 13.2: 137-49.

Bulson, P. S. (1985) Buried Structures: Static and Dynamic Strength. London: Chapman and Hall.

Callister, William D. (1991) Materials Science and Engineering: an Introduction. New York: John Wiley \& Sons.

CertainTeed. PVC Sewer and Drain Pipe [Online]. (2008) Available: http://www.certainteed.com

Cho, S. and Vipulanandan, C. (2005) Flowable Backfill with Flexible Pipe in Trench Condition and FEM Verification. Proceedings of the Pipeline Division Specialty Conference, Houston, Texas, August 21-24, pp. 1079-1088.

Chu, Vincent T.H. (2010) A Self Learning Manual - Mastering Different Fields of Civil Engineering Works [Online]. (2010) Available: http://www.engineeringcivil.com

Cook, R.D., Malkus, D.S., Plesha, M.E., and Witt, R.J. (2003) Concepts and Applications of Finite Element Analysis. John Wiley \& Sons, Inc., Indianapolis, Indiana.

Das, B. M. (2006) Principles of Geotechnical Engineering, $6^{\text {th }}$ Edition. Cengage Learning, Stamford, CT. 
Desai, C.S. and Abel, J.F. (1972) Introduction to the Finite Element Method - A Numerical Method for Engineering Analysis, East-West Edition, West-West Press Private Limited, New Delhi/Madras, India.

Dhar, Ashutosh S., Ian D. Moore, and Timothy J. McGrath. (2004) Two-Dimensional Analyses of Thermoplastic Culvert Deformations and Strains. Journal of Geotechnical and Geoenvironmental Engineering. 130.2:199.

Diamond Plastics Corporation, Specification Data [Online]. (2005) Available: http://www.dpcpipe.com/

Fetter, C. W. (2001) Applied Hydrogeology. Upper Saddle River, NJ: Prentice Hall.

Gassman, S. L., A. J. Schroeder, and R. P. Ray. (2005) Field Performance of High Density Polyethylene Culvert Pipe. Journal of Transportation Engineering 131.2: 160.

Gondle, R.K. and H. Siriwardane. (2008) Finite Element Analysis of Long-Term Performance of Buried High Density Polyethylene Pipes. M.S. Thesis, West Virginia University.

Hartley, J.D. and J.M. Duncan. (1987) E' and Its Variation with Depth. Journal of Transportation Engineering, Vol. 113, No. 5, pp. 538-553.

Hashash, N. (1991) Design and Analysis of Deeply Buried Polyethylene Drainage Pipes, Ph.D.Thesis, Department of Civil Engineering, University of Massachusetts.

Hashash, N., and Selig, E.T. (1990) Analysis of the Performance of a Buried High Density Polyethylene Pipe. Structural Performance of Flexible Pipes, Proceedings of the First National Conference on Flexible Pipes, Sargand, S.M., Mitchell, G.F., \& Hurd, J.O. (eds), October 21-23, Columbus, Ohio, pp. 95-103.

Helwany, Sam. (2007) Applied Soil Mechanics with ABAQUS Applications. Hoboken, NJ: John Wiley.

Hibbitt, H., P. Marcal, and J. Rice. (1970) A Finite Element Formulation for Problems of Large Strain and Large Displacement. International Journal of Solids and Structures 6.8: 1069086.

Horvath, John S. (1998) Mathematical Modeling of the Stress-Strain-Time Behavior of Geosynthetics Using the Findley Equation: General Theory and Application to EPSBlock Geofoam. Rep. no. CE/GE-98-3.

Howard, A.K. (1977) Modulus of Soil Reaction Values for Buried Flexible Pipe. Journal of the Geotechnical Engineering Division, January, pp. 33-43.

Hult, Jan A. H. (1966) Creep in Engineering Structures. Waltham, MA: Blaisdell Pub. 
Janson, L.E. (1985) Investigation of Long Term Creep Modulus of Buried Polyethylene Pipes Subjected to Constant Deflection. Advances in Underground Pipeline Engineering, pp. 253-262.

Janson, L.E. (1995) Long Term Behavior of Buried Polyvinyl Chloride Sewer Pipes. Proceedings of the 9th International Conference on Plastic Pipes, September 1821, Edinburgh, Scotland, UK.

Kang, Jun S., Taek H. Han, Young J. Kang, and Chai H. Yoo. (2009) Short-term and Long-term Behaviors of Buried Corrugated High-density Polyethylene (HDPE) Pipes. Composites Part B: Engineering 40.5: 404-12.

Lewis, R. W., and B. A. Schrefler. (1998) The Finite Element Method in the Static and Dynamic Deformation and Consolidation of Porous Media. Chichester: John Wiley.

Lovisa, Julie, Wayne Read, and Nagaratnam Sivakugan. (2010) Consolidation Behavior of Soils Subjected to Asymmetric Initial Excess Pore Pressure Distributions. International Journal of Geomechanics 10.5: 181.

Masada, T. and Sargand, S. M. (2005) Peaking Deflections of Flexible Thermoplastic Pipe.

Pipelines 2005: Optimizing Pipeline Design, Operations, and Maintenance in Today's Economy. Proceedings of the Pipeline Division Specialty Conference.

McGrath, T. J., Ian D. Moore, and Y. G. Hsuan. (2009) Updated Test and Design Methods for Thermoplastic Drainage Pipe. Washington, D.C.: Transportation Research Board.

McGrath, T.J., and B.W. Schafer. (2003) Parallel Plate Testing and Simulation of Corrugated Plastic Pipe. Transportation Research Board Annual Meeting.

Moore, I.D. (1995) Three-dimensional Response of Deeply Buried Profiled Polyethylene Pipe. Transportation Research Record, 1514, Transportation Research Board, Washington, D.C., pp. 49-58.

Moore, Ian D., and Chuntao Zhang. (1998) Nonlinear Predictions for HDPE Pipe Response under Parallel Plate Loading. Journal of Transportation Engineering 124.3: 286. 
Moore, Ian D., and Fuping Hu. (1996) Linear Viscoelastic Modelling of Profiled High Density Polyethylene Pipe. Canadian Journal of Civil Engineering 23.2: 395-407.

Moser, A. P. (1990) Buried Pipe Design. McGraw-Hill, Inc., New York.

Moser, A.P. (2008) Buried Pipe Design. McGraw-Hill, Inc., New York.

Petroff, L.J. (1993) Ring Bending Stiffness and the Design of Flexible Pipe. Structural Performance of Pipes, Proceedings of the Second Conference on Structural Performance of Pipes, $\quad$ Sargand, G.F., Mitchell, G.F., \& Hurd, J.O (eds), March 14-17, Columbus, Ohio, pp.125-136.

Sargand, S. M., Gayle F. Mitchell, and J. O. Hurd. (1993) Structural Performance of Pipes: Proceedings of the Second Conference on Structural Performance of Pipes, Columbus, Ohio, 14-17 March 1993. Rotterdam: A.A. Balkema.

Sargand, S. M., T. Masada, B. Tarawneh, and D. Gruver. (2005) Field Performance and Analysis of Large-Diameter High-Density Polyethylene Pipe under Deep Soil Fill. Journal of Geotechnical and Geoenvironmental Engineering 131.1: 39.

Selig, E.T. (1988) Soil Parameter for Design of Buried Pipelines. Pipeline Infrastructure; Proceedings of the Conference, June 6-7, Boston, Massachusetts.

Somayaji, Shan. (2001) Civil Engineering Materials. Upper Saddle River, NJ: Prentice Hall.

Simulia (2010) ABAQUS User’s Manual. Simulia, Providence, RI.

Spangler and Handy. (1982) Vertical Soil Arching and TerraFlex. Soil Engineering.. 4th ed. Harper and Row, 1982.

Spangler, M. G. (1958, 1994) A Practical Application of the Imperfect Ditch Method of Construction. Highway Research Board Proceedings 37: 271-77. 
Spangler, M.G. (1941) The Structural Design of Flexible Pipe Culverts. Bulletin 153, Iowa Engineering Experiment Station, Ames, Iowa, USA. Spangler, Merlin Grant, and Richard Lincoln.

Suleiman, M., R. Lohnes, T. Wipf, and F. Klaiber. (2003) Analysis of Deeply Buried Flexible Pipes. Transportation Research Record 1849.1: 124-34.

Terzaghi, K. (1925) Erdbaumechanik auf Bodenphysikalischer Grundlager. Deuticke, Vienna.

Watkins, Reynold King., and L. R. Anderson. (1999) Structural Mechanics of Buried Pipes. Boca Raton, FL: CRC.

Zhang, C., and Moore, I. D. (1998) Nonlinear Finite Element Analysis for Thermoplastic Pipes. Transportation Research Record 1624, Transportation Research Board, Washington, D.C., pp. 225-230.

Zhao, L., N.M. Beuse, and G.E.O. Widera. (2001) External Pressure Testing of 4-in-Dia HighDensity Polyethylene Pipe. J. Pressure Vessel Techno 123.3.398.

Zienkiewicz, O. C. and Taylor, R. L. (1987). The Finite Element Method. $4^{\text {th }}$ Edition, McGraw Hill Book Company, New York. 


\section{APPENDIX A: CREEP RESULTS}

Analyses of cases shown in Table A.1 and Table A.2 were completed in a manner similar to what was presented in Chapter 6, Section 6.3 of the report. Table A.1 shows the pipe deflections for HDPE pipes with clay backfill under the influence of creep. Table A.2 shows pipe deflections for the same cases as a percentage of pipe diameters. As can be seen from these tables, none of the pipes reach 5\% pipe deflection under the combined influence of creep and consolidation. As can be seen from these tables, even for the cases corresponding to trench-width ratio of 1.5, the pipes did not reach $5 \%$ deflections under the self-weight of soil. These results suggest the possibility of using smaller trench width ratios. However, the influence of trenchwidth ratio on pipe deflections depends on pipe diameter and the backfill material.

Table A.1: Deflection of HDPE pipe installed in clay material (inches)

\begin{tabular}{|c|c|c|c|c|c|c|}
\hline \multicolumn{7}{|c|}{ HDPE Creep Analyses: Clay Pipe Backfill } \\
\hline & \multicolumn{2}{|c|}{ Diameter: 24-inch } & \multicolumn{3}{c|}{ Diameter: 60-inch } \\
\hline $\begin{array}{c}\text { Trench-Width } \\
\text { Ratio }\end{array}$ & 1.5 & 2.0 & 2.5 & 1.5 & 2.0 & 2.5 \\
\hline Depth: 10 feet & -- & 0.130 & -- & -- & 0.337 & - \\
\hline Depth: 20 feet & -- & 0.176 & -- & -- & 0.478 & - \\
\hline Depth: 30 feet & -- & 0.616 & -- & -- & 1.60 & -- \\
\hline Depth: 50 feet & -- & 1.02 & -- & 2.62 & 2.62 & 2.63 \\
\hline
\end{tabular}


Table A.2: Deflection of HDPE pipe installed in clay material (percentage)

\begin{tabular}{|c|c|c|c|c|c|c|}
\hline \multicolumn{7}{|c|}{ HDPE Creep Analyses: Clay Pipe Backfill } \\
\hline & \multicolumn{2}{|c|}{ Diameter: 24-inch } & \multicolumn{3}{l|}{ Diameter: 60-inch } \\
\hline $\begin{array}{c}\text { Trench-Width } \\
\text { Ratio }\end{array}$ & 1.5 & 2.0 & 2.5 & 1.5 & 2.0 & 2.5 \\
\hline Depth: 10 feet & -- & 0.542 & -- & -- & 0.562 & -- \\
\hline Depth: 20 feet & -- & 0.733 & -- & -- & 0.797 & -- \\
\hline Depth: 30 feet & -- & 2.567 & -- & -- & 2.667 & -- \\
\hline Depth: 50 feet & -- & 4.250 & -- & 4.367 & 4.367 & 4.383 \\
\hline
\end{tabular}

Table A.3 shows the pipe deflections for HDPE pipes with granular stone backfill under the influence of creep. Table A.4 shows pipe deflections for the same cases as a percentage of pipe diameters. As can be seen from these tables, none of the pipes with granular stone backfill reach $5 \%$ pipe deflection under the combined influence of creep and consolidation. The conclusions that can be drawn from the results for granular backfill materials are similar to those for clay backfill materials, and none of the pipes reach 5\% pipe deflections under the self-weight of soil. 
Table A.3: Deflection of HDPE pipe installed in granular stone (inches)

\begin{tabular}{|c|c|c|c|c|c|c|}
\hline \multicolumn{2}{|c|}{ HDPE Creep Analyses: Granular Pipe Backfill } \\
\hline & \multicolumn{2}{|c|}{ Diameter: 24-inch } & \multicolumn{3}{c|}{ Diameter: 60-inch } \\
\hline $\begin{array}{c}\text { Trench-Width } \\
\text { Ratio }\end{array}$ & 1.5 & 2.0 & 2.5 & 1.5 & 2.0 & 2.5 \\
\hline Depth: 10 feet & -- & 0.388 & -- & -- & 0.316 & - \\
\hline Depth: 20 feet & -- & 0.144 & -- & -- & 0.484 & - \\
\hline Depth: 30 feet & -- & 0.366 & -- & -- & 1.09 & - \\
\hline Depth: 50 feet & -- & 0.599 & -- & 1.91 & 1.75 & 1.66 \\
\hline
\end{tabular}

Table A.4: Deflection of HDPE pipe installed in granular material (percentage)

\begin{tabular}{|c|c|c|c|c|c|c|}
\hline \multicolumn{7}{|c|}{ HDPE Creep Analyses: Granular Pipe Backfill } \\
\hline & \multicolumn{2}{|c|}{ Diameter: 24-inch } & \multicolumn{3}{c|}{ Diameter: 60-inch } \\
\hline $\begin{array}{c}\text { Trench-Width } \\
\text { Ratio }\end{array}$ & 1.5 & 2.0 & 2.5 & 1.5 & 2.0 & 2.5 \\
\hline Depth: 10 feet & -- & 1.617 & -- & -- & 0.527 & - \\
\hline Depth: 20 feet & -- & 0.600 & -- & -- & 0.807 & -- \\
\hline Depth: 30 feet & -- & 1.525 & -- & -- & 1.817 & -- \\
\hline Depth: 50 feet & -- & 2.496 & -- & 3.183 & 2.917 & 2.767 \\
\hline
\end{tabular}


Analyses of cases shown in Table A.5 and Table A.6 were completed in a manner similar to what was presented in Chapter 6, Section 6.7, of the report. Table A.5 shows the pipe deflections for PVC pipes with clay backfill under the combined influence of creep. Table A.6 shows pipe deflections for the same cases as a percentage of pipe diameters. As can be seen from these tables, none of the pipes reach 5\% pipe deflection under the combined influence of creep and consolidation. As can be seen from these tables, even for the cases corresponding to trenchwidth ratio of 1.5 , the pipes did not reach $5 \%$ deflections under the self-weight of soil. These results suggest the possibility of using smaller trench-width ratios. However, the influence of trench-width ratio on pipe deflections depends on pipe diameter and the backfill material.

Table A.5: Deflection of PVC pipe installed in clay backfill material (inches)

\begin{tabular}{|c|c|c|c|}
\hline \multicolumn{3}{|c|}{ PVC Creep Analyses: Clay Pipe Backfill } \\
\hline & \multicolumn{3}{|c|}{ Diameter: 24-inch } \\
\hline Trench-Width Ratio & 1.5 & 2.0 & 2.5 \\
\hline Depth: 10 feet & 0.090 & 0.080 & -- \\
\hline Depth: 20 feet & 0.107 & 0.087 & -- \\
\hline Depth: 30 feet & 0.468 & 0.471 & -- \\
\hline Depth: 50 feet & 0.772 & 0.777 & -- \\
& & & \\
\hline
\end{tabular}


Table A.6: Deflection of PVC pipe installed in clay backfill material (percentage)

\begin{tabular}{|c|c|c|c|}
\hline \multicolumn{3}{|c|}{ PVC Creep Analyses: Clay Pipe Backfill } \\
\hline & \multicolumn{3}{|c|}{ Diameter: 24-inch } \\
\hline Trench-Width Ratio & 1.5 & 2.0 & 2.5 \\
\hline Depth: 10 feet & 0.375 & 0.333 & -- \\
\hline Depth: 20 feet & 0.446 & 0.363 & -- \\
\hline Depth: 30 feet & 1.950 & 1.963 & -- \\
\hline Depth: 50 feet & 3.217 & 3.238 & -- \\
\hline
\end{tabular}

Table A.7 shows the pipe deflections for PVC pipes with granular stone backfill under the influence of creep. Table A.8 shows pipe deflections for the same cases as a percentage of pipe diameters. As can be seen from these tables, none of the pipes with granular stone backfill reach $5 \%$ pipe deflection under the combined influence of creep and consolidation. The conclusions that can be drawn from the results for granular backfill materials are similar to those for clay backfill materials, and none of the pipes reach $5 \%$ pipe deflections under the self-weight of soil. 
Table A.7: Deflection of PVC pipe installed in granular stone backfill material (inches)

\begin{tabular}{|c|c|c|c|}
\hline \multicolumn{4}{|c|}{$\begin{array}{c}\text { PVC Creep Analyses: Granular Pipe } \\
\text { Backfill }\end{array}$} \\
\hline & \multicolumn{3}{|c|}{ Diameter: 24-inch } \\
\hline Trench-Width Ratio & 1.5 & 2.0 & 2.5 \\
\hline Depth: 10 feet & 0.066 & 0.049 & -- \\
\hline Depth: 20 feet & 0.098 & 0.067 & -- \\
\hline Depth: 30 feet & 0.280 & 0.234 & -- \\
\hline Depth: 50 feet & 0.458 & 0.383 & -- \\
\hline
\end{tabular}

Table A.8: Deflection of PVC pipe installed in granular stone backfill material (percentage)

\begin{tabular}{|c|c|c|c|}
\hline \multicolumn{4}{|c|}{$\begin{array}{c}\text { PVC Creep Analyses: Granular Pipe } \\
\text { Backfill }\end{array}$} \\
\hline & \multicolumn{3}{|c|}{ Diameter: 24-inch } \\
\hline Trench-Width Ratio & 1.5 & 2.0 & 2.5 \\
\hline Depth: 10 feet & 0.275 & 0.204 & -- \\
\hline Depth: 20 feet & 0.408 & 0.279 & -- \\
\hline Depth: 30 feet & 1.167 & 0.975 & -- \\
\hline Depth: 50 feet & 1.908 & 1.596 & -- \\
\hline
\end{tabular}


APPENDIX B: COMPARISON OF TIME-DEPENDENT PIPE DEFLECTIONS

Table B.1: Comparison of pipe deflections (percentage)

\begin{tabular}{|c|c|c|c|c|c|c|}
\hline \multicolumn{7}{|c|}{ 24-inch HDPE Pipe with a TW of 2.0 in Clay } \\
\hline \multirow{4}{*}{$\begin{array}{c}\text { Creep + Consolidation } \\
\text { Conditions }\end{array}$} & 10 feet & 18.2 & 79.4 & 86.4 & 91.9 & 100 \\
\cline { 2 - 7 } & 20 feet & 10.0 & 77.0 & 87.2 & 92.3 & 100 \\
\cline { 2 - 7 } & 30 feet & 43.2 & 84.6 & 92.6 & 95.6 & 100 \\
\cline { 2 - 7 } & 50 feet & 41.9 & 81.7 & 92.8 & 95.8 & 100 \\
\hline \multirow{4}{*}{$\begin{array}{c}\text { Year } \\
\text { Creep Condition }\end{array}$} & 10 feet & 81.7 & 86.0 & 90.7 & 94.5 & 100 \\
& 20 feet & 77.4 & 82.6 & 88.4 & 93.1 & 100 \\
\cline { 2 - 7 } & 30 feet & 86.9 & 90.1 & 93.5 & 96.1 & 100 \\
\hline & 50 feet & 86.9 & 90.1 & 93.5 & 96.1 & 100 \\
\hline
\end{tabular}


Table B.2: Comparison of pipe deflections (percentage)

\begin{tabular}{|c|c|c|c|c|c|c|}
\hline \multicolumn{7}{|c|}{ 24-inch HDPE Pipe with a TW of 2.0 in Granular Stone } \\
\hline & & $\begin{array}{l}\text { One } \\
\text { Day }\end{array}$ & $\begin{array}{l}\text { One } \\
\text { Month }\end{array}$ & $\begin{array}{l}\text { One } \\
\text { Year }\end{array}$ & $\begin{array}{l}\text { Five } \\
\text { Years }\end{array}$ & $\begin{array}{l}\text { Fifty } \\
\text { Years }\end{array}$ \\
\hline \multirow{4}{*}{$\begin{array}{c}\text { Creep + Consolidation } \\
\text { Conditions }\end{array}$} & 10 feet & 60.8 & 84.9 & 90.1 & 94.2 & 100 \\
\hline & 20 feet & 56.0 & 84.1 & 89.9 & 94.0 & 100 \\
\hline & 30 feet & 54.1 & 86.7 & 92.2 & 95.4 & 100 \\
\hline & 50 feet & 53.1 & 85.3 & 92.3 & 95.4 & 100 \\
\hline \multirow{4}{*}{ Creep Condition } & 10 feet & 80.7 & 85.4 & 90.4 & 94.3 & 100 \\
\hline & 20 feet & 78.1 & 83.4 & 89.1 & 93.6 & 100 \\
\hline & 30 feet & 84.8 & 88.5 & 92.4 & 95.5 & 100 \\
\hline & 50 feet & 84.8 & 88.5 & 92.5 & 95.6 & 100 \\
\hline
\end{tabular}

